DANMARKS GEOLOGISKE UNDERS $\varnothing$ GELSE · SERIE A · NR. 12 MILJØMINISTERIET · Geological Survey of Denmark

\title{
Jurassic - Lower Cretaceous lithostratigraphic nomenclature for the Danish Central Trough
}

BY

THORKILD FELDTHUSEN JENSEN, LISE HOLM, NILS FRANDSEN AND OLAF MICHELSEN

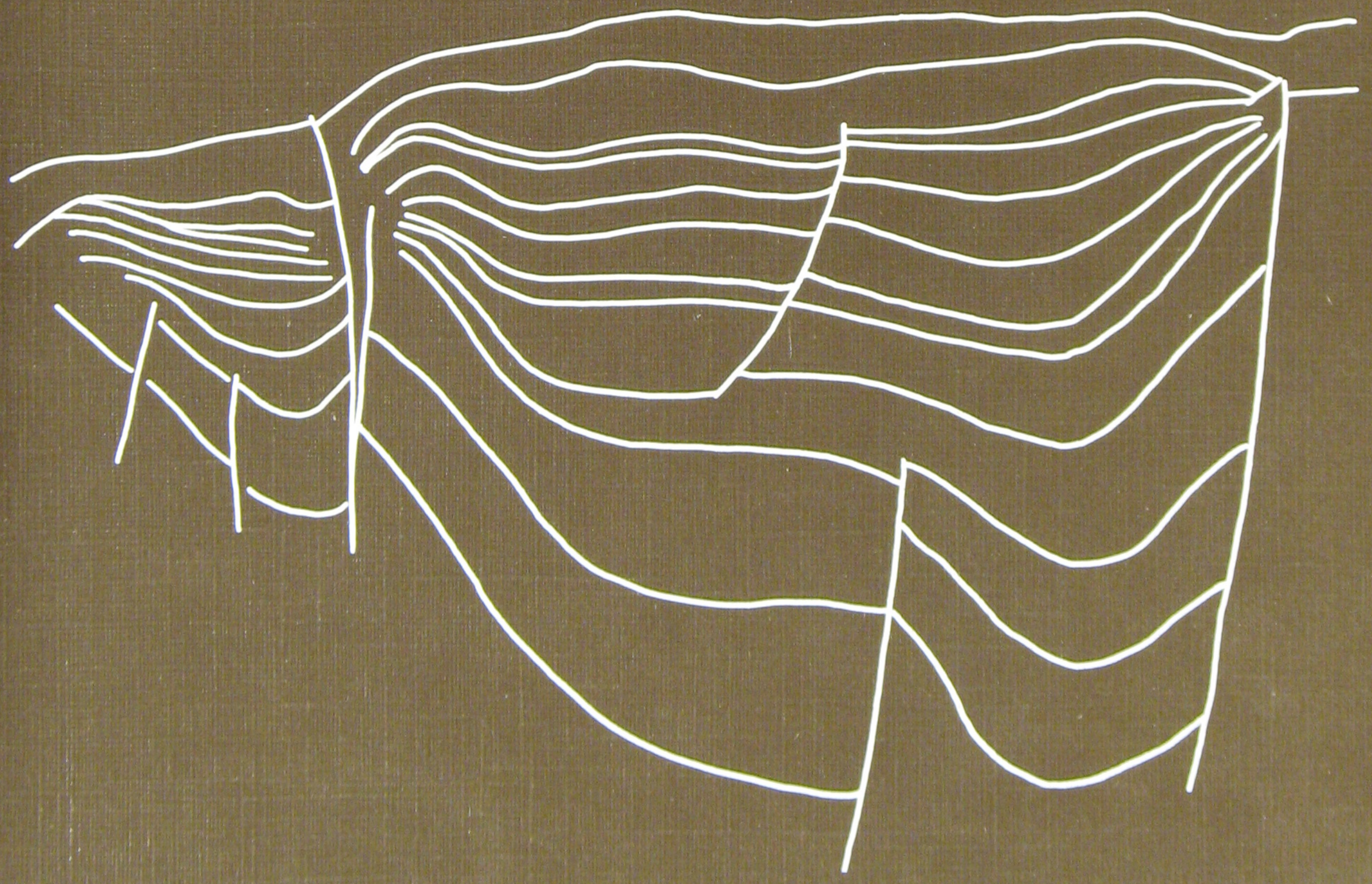

I kommission hos C. A. Reitzels forlag · København 1986 


\section{Jurassic - Lower Cretaceous lithostratigraphic nomenclature for the Danish Central Trough}

BY

THORKILD FELDTHUSEN JENSEN, LISE HOLM, NILS FRANDSEN AND OLAF MICHELSEN

I kommission hos C. A. Reitzels forlag · København 1986 


\section{A contribution to \\ EFP-83 project: \\ Jurassic-Lower Cretaceous stratigraphy and \\ basin development of the Danish North \\ Sea sector}

Key-words:

North Sea, Denmark, Jurassic,

Lower Cretaceous, Lithostratigraphy

Vignette

East-west section through the Tail End Graben

DGU Serie A nr. 12

ISBN 87-421-0745-3

ISSN 0901-0270

Oplag: 1200

Tryk: AiO Tryk as, Odense

Tegning: Helle Zetterwall, Lise-Lotte Thorsen og Birgitte Enig

Dato: 1986-12-31

Thorkild Feldthusen Jensen og Olaf Michelsen,

Danmarks Geologiske Undersøgelse,

Thoravej 31, 2400 København NV

Lise Holm, nuværende adresse:

Energistyrelsen, Landemærket 11, 1119 København K

Nils Frandsen, nuv. adresse: Dopas A/S

Agern Allé 24-26, 2970 Hørsholm

Redaktion: Leif Banke Rasmussen

(C) Danmarks Geologiske Undersøgelse,

Thoravej 31, DK-2400 København NV 


\section{Preface}

The present paper is one of several reports issued as the result of a research project carried out by the Geological Survey of Denmark in cooperation with the Geological Institute at the University of Copenhagen. The project has been financed by special contributions given by the Ministry of Energy for the period 1st of August 1983 to 31st of December 1985.

The project was entitled "Jurassic - Lower Cretaceous stratigraphy and basin development of the Danish North Sea sector". It has been decided to limit the study area to the Danish Central Trough, and furthermore the effort has been concentrated on the Middle Jurassic, the Upper Jurassic, and the Lower Cretaceous.

The scope of the project was to coordinate analyses of the stratigraphy, facies development and burial history in order to create a basis for predicting possible occurrences of reservoir rocks. The following reports (including the present one) will be printed in the series published by the Geological Survey of Denmark and probably issued in 1986:

Frandsen, N.: Middle Jurassic deltaic and coastal deposits in the Lulu-1 well of the Danish Central Trough.
Heilmann-Clausen, C.: Lower Cretaceous dinoflagellate biostratigraphy in the Danish Central Trough.

Hoelstad, T.: Palynology and palynofacies analyses of the Middle Jurassic to Lower Cretaceous in the Danish Central Trough.

Hoelstad, T.: Palynology of the Middle Jurassic Lower Graben Sand Formation of the U-1 well, Danish Central Trough.

Jensen, T.F., Holm, L., Frandsen, N. \& Michelsen, O.: Jurassic - Lower Cretaceous lithostratigraphic nomenclature for the Danish Central Trough.

Møller, J.J.: Seismic structural mapping of the Middle and Upper Jurassic in the Danish Central Trough.

Poulsen, N.: Callovian (Jurassic) to Ryazanian (Cretaceous) dinoflagellate biostratigraphy of the Danish Central Trough.

Thomsen, E.: Lower Cretaceous nannofossil biostratigraphy in the Danish Central Trough.

Vejbæk, O.V.: Seismic stratigraphy and tectonic evolution of the Lower Cretaceous in the Danish Central Trough.

Michelsen, O., Frandsen, N., Holm, L., Jensen, T.F., Møller, J.J. \& Vejbæk, O. V.: Jurassic - Lower Cretaceous of the Danish Central Trough; - depositional environments, tectonism, and reservoirs.

DGU, 30th December $1985 \quad$ Olaf Michelsen 


\section{Contents}

List of figures

Abstract ....................... 9

Introduction. . . . . . . . . . . . . . 10

Lithostratigraphic methods . . . . . . . . . . 10

Chronostratigraphic framework ........... 11

Structural nomenclature . . . . . . . . . . . . 11

Basin framework ................. 12

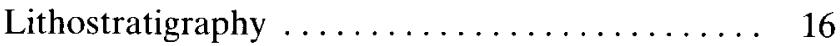

Fjerritslev Formation............. 17

Bryne Formation .................. 19

Central Graben Group ............... 20

Lower Graben Sand Formation . . . . . . . . . . . 22

Middle Graben Shale Formation.......... 23

Lola Formation . . . . . . . . . . . . . . . 24

Heno Formation . . . . . . . . . . . . 29
Farsund Formation $\ldots \ldots \ldots \ldots \ldots \ldots \ldots, 32$

Hot unit $\ldots \ldots \ldots \ldots \ldots \ldots \ldots \ldots \ldots \ldots \ldots$

Poul Formation................... 35

Cromer Knoll Group . . . . . . . . . . . . . . 36

Valhall Formation. . . . . . . . . . . . . 38

Leek Member ................. 42

Vyl Formation................. 46

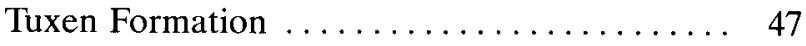

Munk Marl Bed . . . . . . . . . . . . . . . . . 48

Sola Formation . . . . . . . . . . . . . . . . . . . 49

Rødby Formation ................. 50

Acknowledgements .................. 54

References.................... 55

Lithostratigraphic table ............. 57 


\section{List of Figures}

Fig. 1: Jurassic structural outline of the Danish Central Trough, including location of wells penetrating the Jurassic sequence (by Jens Jørgen Møller). . . . . .

Fig. 2: Early Cretaceous structural outline of the Danish Central Trough, including location of wells penetrating the Lower Cretaceous sequence (by Ole Valdemar Vejbakk). ....................

Fig. 3: Thickness and distribution of the seismic sequence between the Mid and Late Cimmerian Unconformities (by Jens Jørgen Møller)..........

Fig. 4: Lower Cretaceous lithostratigraphic correlation chart (compiled and modified from Larsen (1966), Schott (1969), Kemper (1973a \& b), Rhys (1974), Rawson et al. (1977), Deegan \& Scull (1977), Wood \& Smith (1978), Kemper (1979), NAM \& RGD (1980), Crittenden (1982), Hesjedal \& Hamar (1983), Vollset \& Doré (1984), Edwin Kemper (pers. comm. 1985))....................

Fig. 5: Jurassic lithostratigraphic correlation chart (compiled on the basis of Bertelsen (1978), Michelsen (1978a), NAM \& RGD (1980), Herngreen \& de Boer (1984), Michelsen et al. (1984), Vollset \& Doré (1984)).............................

Fig. 6: The Danish O-1 well. Reference section for the Fjerritslev Formation (legend fig. 33)..........

Fig. 7: The Fjerritslev Formation and the Central Graben Group in the $U-1, M-8$ and $O-1$ wells of the Danish Central Trough.

Fig. 8: The Danish Lulu-1 well. Reference section for the Bryne Formation (legend fig. 33).........

Fig. 9: Map of the distribution of the Middle Jurassic Bryne Formation and Central Graben Group....

Fig. 10: The Danish U-1 well. Reference section for the Lower Graben Sand Formation (legend fig. 33)..

Fig. 11: The Danish U-1 well. Reference section for the Middle Graben Shale Formation (legend fig. 33).

Fig. 12: The Danish U-1 well. Type section for the Lola Formation (legend fig. 33) ................

Fig. 13: The Lola, Farsund, and Poul Formations and the hot unit in the $U-1, M-8, G-1, E-1$ and $V-1$ wells, the Danish Central Trough. ............

Fig. 14: The Lola, Farsund, and Heno Formations and the hot unit in the W-1, I-1, Bo-1, Adda-1 and Lulu-1 wells, the Danish Central Trough.......

Fig. 15: Thickness and distribution of the seismic sequence corresponding to the Middle Jurassic and the Lola Formation (by Jens Jørgen Møller)..... .

Fig. 16: The Danish W-1 well. Type section for the Heno Formation (legend fig. 33)..............

Fig. 17: The Lola and Heno Formations in the Danish Q-1 well (legend fig. 33)...............

Fig. 18: The Danish U-1 well. Reference section for the Farsund Formation (legend fig. 33). ..........

Fig. 19: Thickness and distribution of the seismic sequence corresponding to the Farsund Formation (by Jens Jørgen Møller). . . . . . . . . . . . .

Fig. 20: The Danish Bo-1 well. Type section for the informal hot unit (legend fig. 33)..............

Fig. 21: Extension of the seismic sequence corresponding to the uppermost part of the Farsund Formation which may comprise the hot unit (by Jens Jørgen Møller).........................

Fig. 22: The Danish V-1 well. Type section for the Poul Formation (legend fig. 33)................

Fig. 23: Thickness and distribution of the seismic sequence corresponding to the Cromer Knoll Group (by Ole Valdemar Vejbak).................

Fig. 24: The Cromer Knoll Group in the Norwegian $2 / 11-1$ well..........................

Fig. 25: Thickness and distribution of the seismic sequence corresponding to the Valhall Formation (by Ole Valdemar Vejbaek). ...................

Fig. 26: The Danish I-1 well. Type section for the Sola and Tuxen Formations and the Leek Member, and reference section for the Valhall Formation and the Munk Marl Bed (legend fig. 33)...............

Fig. 27: The Danish Bo-1 well. Reference section for the Rødby, Sola, Tuxen, and Valhall Formations and the Leek Member (legend fig. 33)..........

Fig. 28: Extension of the seismic sequence corresponding to the lower part of the Vallhall Formation including the Leek Member (modified from Vejbak 1986). Distribution and thickness of the Leek Member as encountered in wells. .............

Fig. 29: The Cromer Knoll Group in the Danish I-1, Bo-1, Adda-2, Adda-1 and E-1 wells and in the Norwegian 2/11-1 well...................

Fig. 30: The Danish V-1 well. Type section for the Vyl Formation (legend fig. 33). The ages are based on three $S W C$ 's at 8954, 9066 and $9198 \mathrm{ft} . b . K B$ and one cuttings sample at 8930-40 ft. b. KB (cf. Heilmann-Clausen 1986).

Fig. 31: Thickness and distribution of the seismic sequence corresponding to the Tuxen, Sola and Rødby Formations (by Ole Valdemar Vejbak)...

Fig. 32: Extension of the seismic sequence corresponding to the Tuxen, Sola and Rødby Formations (modified from Vejbak 1986). Distribution and thickness of the Tuxen, Sola and Rødby Formations as encountered in wells. ...............

Fig. 33: Lithological legend for type and reference sections. .............................

31 


\section{Abstract}

The Jurassic and Lower Cretaceous sequences have been subdivided into lithostratigraphic units. The subdivision is primarily based on interpretation of petrophysical logs like gamma ray, sonic, neutron and density logs. The lithology descriptions are based on evaluation of logs and descriptions of cuttings samples, in a few intervals supplemented by sedimentological characteristics interpreted from core samples. Biostratigraphic analyses as well as seismic interpretations have been used for correlation from well to well and for description of the sediment bodies.

As far as possible the lithostratigraphic units estab- lished in the adjacent regions have been extended into the Danish region. In the Jurassic sequence the following new formations are established: Lola Formation, Heno Formation, and Poul Formation. Furthermore, a hot unit is separated from the Farsund Formation. The Lower Cretaceous Valhall Formation is slightly emended, as the new Tuxen Formation and Sola Formation are separated from it. The lowest part of the Valhall Formation is defined as the Leek Member. Finally, the Vyl Formation is established as a formation marginal to the basin. 


\section{Introduction}

The Jurassic and Lower Cretaceous sequences in the Danish Central Trough region have previously been treated in connection with biostratigraphic subdivision of individual well profiles (Rasmussen 1974 and 1978, Michelsen 1978a) and with regional description (Michelsen 1982). In the latter paper, a preliminary lithostratigraphic subdivision was presented for the Jurassic sequence, mainly using informal names.

Within the last decade, several papers have been published concerning lithostratigraphic subdivision of the Jurassic to Lower Cretaceous sequences in the North Sea. For the southern North Sea a first description covering the British sector was given by Rhys (1974). Later, NAM \& RGD (1980) and Crittenden (1982) described the deposits known from the Dutch sector, and correlation with the British sector was proposed by the latter author. Deegan \& Scull (1977) published a comprehensive paper on the lithostratigraphy of the Permian-Tertiary in the central and northern North Sea. Their subdivision of the Triassic and Jurassic of the Norwegian sector was revised by Vollset \& Doré (1984).

The present paper is a first attempt to establish formal lithostratigraphic units within the Danish Central Trough and to correlate these with units described from the adjacent regions. As far as possible, established units have been extended into the Danish region. However, towards the south the work has been hampered by lack of released German well data and by a Dutch lithostratigraphy suffering from absence of detailed descriptions of the established lithostratigraphic units.

Definitions, descriptions and correlations are primarily based on studies of petrophysical logs, as described in a later section of this paper, and cuttings samples. Core samples exist from a few wells and a few of them have undergone special sedimentological investigations (Koch 1983, Frandsen 1986). Furthermore, biostratigraphic studies and seismic interpretations have been important for carrying out the correlation from well to well and for evaluation of geometry and facies variation of the sediment bodies. A lithostratigraphic subdivision based on a thorough understanding of sedimentary evolution and facies variation in the entire region is important in connection with the seismic stratigraphy for establishing a geo-dynamic model for the basin.

\section{Lithostratigraphic methods}

The lithostratigraphy presented herein is basically a mixture of log stratigraphy and classic lithostratigraphy. It essentially follows the International Subcommission on Stratigraphic Classification (Hedberg 1976). The main tools used in the study are the most important lithology-dependent petrophysical logs such as gamma ray, sonic velocity, neutron and density. Boundaries between lithostratigraphic units are defined by means of these logs. The lithologies of the various lithostratigraphic units are interpreted from both company reports and internal reports of the Geological Survey of Denmark dealing with the lithology of sidewall cores and cuttings samples. Such lithology determination is supported and depth corrected by gamma ray, sonic velocity, neutron and density log interpretation. Conventional cores from the investigated sections are rare and accurate lithology determination and interpretation of the depositional environments naturally suffer from the lack of core information.

The interpreted lithology of formation and member type sections proposed in this paper is illustrated together with gamma ray - sonic velocity logs in scale 1:2000. The lithostratigraphic units extended from adjacent areas are represented by appropriate Danish Central Trough reference sections to illustrate their development here.

Main emphasis is laid on the fact that the primary tools, in practical work with subsurface litho-units, are the petrophysical logs. Therefore, to show the broadness and spatial variation of the lithostratigraphic units with respect to log characteristics and log boundaries, a large number of wells are illustrated on correlation diagrams by their gamma ray and sonic velocity logs. All released wells encountering the Lower Jurassic Fjerritslev Formation and the Middle Jurassic Bryne Formation and Central Graben Group are illustrated by log segments in scale $i: 3000$. Most wells encountering the Upper Jurassic Lola, Heno, Farsund, Poul Formations, and hot unit are illustrated in scale 1:4000. Finally, the most illustrative wells encountering the Cromer Knoll Group are illustrated by logs in scale 1:3000.

A total of 18 released wells encountering Jurassic Lower Cretaceous sediments in the Danish Central Trough were investigated. Depth and thickness data of all lithostratigraphic units above bed rank are listed in the lithostratigraphic table. Reconnaissance work was done in adjoining areas to check the utility of the established lithostratigraphic units on a more regional scale. 


\section{Chronostratigraphic framework Structural nomenclature}

In the lithostratigraphic section, age names are used to indicate the approximate age of the lithostratigraphic units. For some well sections, further stratigraphic details are to be found in Heilmann-Clausen (1986), Thomsen (1986) and Poulsen (1986). In these papers as well as in the present one, Boreal stage terminology is used as recommended by Casey and Rawson (1973) and Riley (1977). The Jurassic-Cretaceous boundary coincides with the boundary between the Volgian and Ryazanian, or between the Lamplughi and Runctoni ammonite Zones. The base of the Volgian stage coincides with the base of the Elegans ammonite Zone.

The Middle - Upper Jurassic boundary is regarded as coincident with the Callovian - Oxfordian boundary, and the Aalenian is regarded as the lowermost stage of the Middle Jurassic. For more detailed information on the chronostratigraphy and for discussion of the correlation of chronostratigraphic units the reader is referred to Heilmann-Clausen (1986) and Poulsen (1986).
The structural features referred to in this paper are outlined on two maps showing Jurassic and Lower Cretaceous structural elements (figs. 1 and 2). The structural nomenclature primarily follows the proposals of Rønnevik et al. (1975) and Gowers \& Sæbøe (1985) with the modifications introduced by Møller (1986) and Vejbæk (1986). A single point is worth mentioning. The term "Central Graben" is replaced by "Central Trough" for reasons discussed by both Gowers \& Sæbøe (1985) and Rønnevik et al. (1975). 


\section{Basin framework}

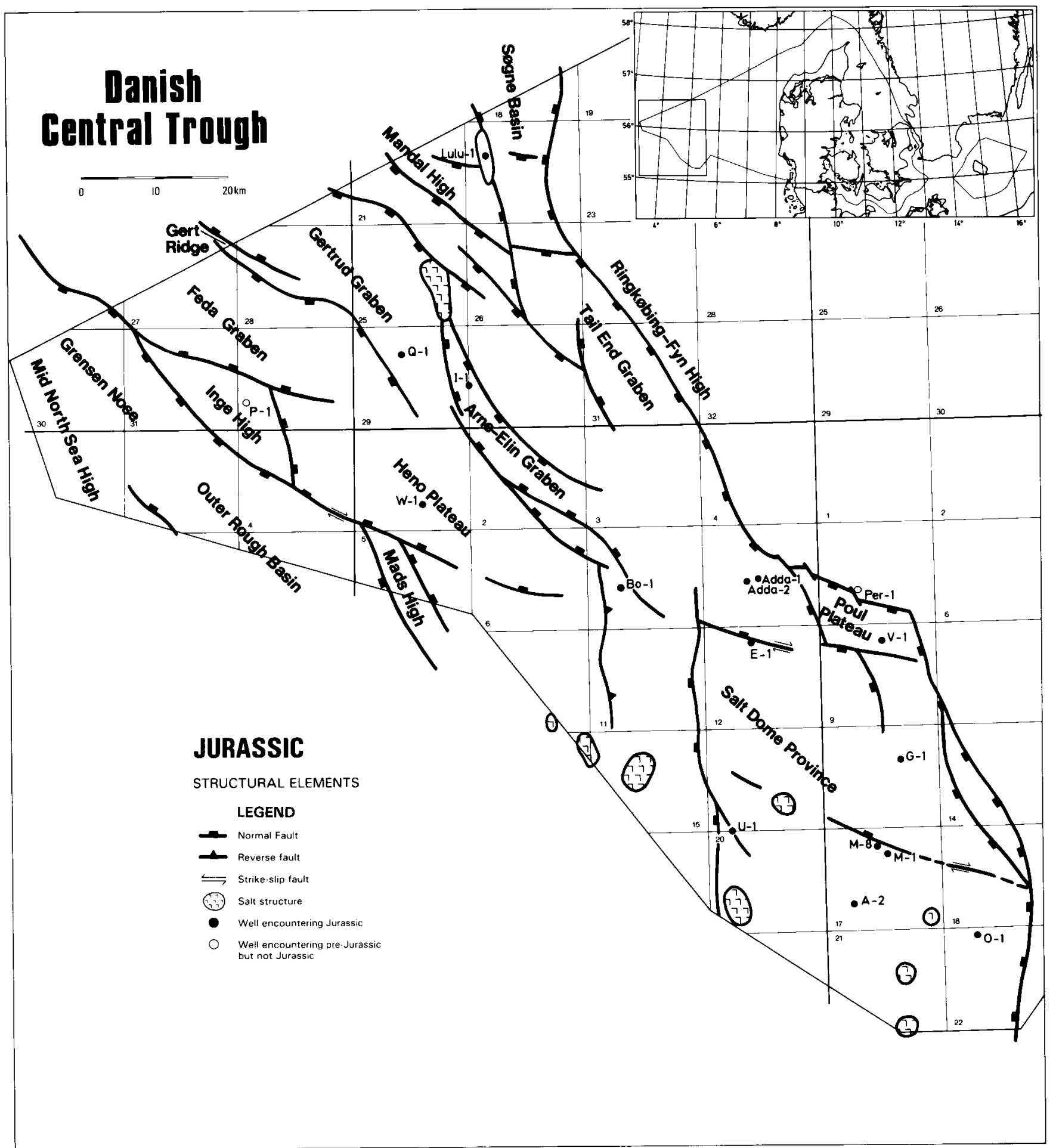

Fig. 1: Jurassic structural outline of the Danish Central Trough, including location of wells penetrating the Jurassic sequence (by Jens Jørgen Møller). 
The basin evolution during the Jurassic and the Early Cretaceous is outlined below as the background for the established lithostratigraphy. The basin evolution is described on the basis of studies presented by Gowers \& Sæbøe (1985), Møller (1986) and Vejbæk (1986).

During the Early Jurassic the differential subsidence that began in the Early Triassic continued with activity along a NNW-SSE fault trend (fig. 1). Sedimentation was dominated by clays, as elsewhere in the North Sea region, probably covering the main part of the Central Trough. Released well data show that only sediments of Hettangian to Sinemurian age are preserved, and that the present day distribution is restricted. Uplift and erosion during the early Middle Jurassic (the Mid Cimmerian tectonic phase) probably removed all but isolated remnants of this Lower Jurassic sequence.

The presence of Middle Jurassic fluvio-deltaic deposits is documented by released wells only in the Søgne

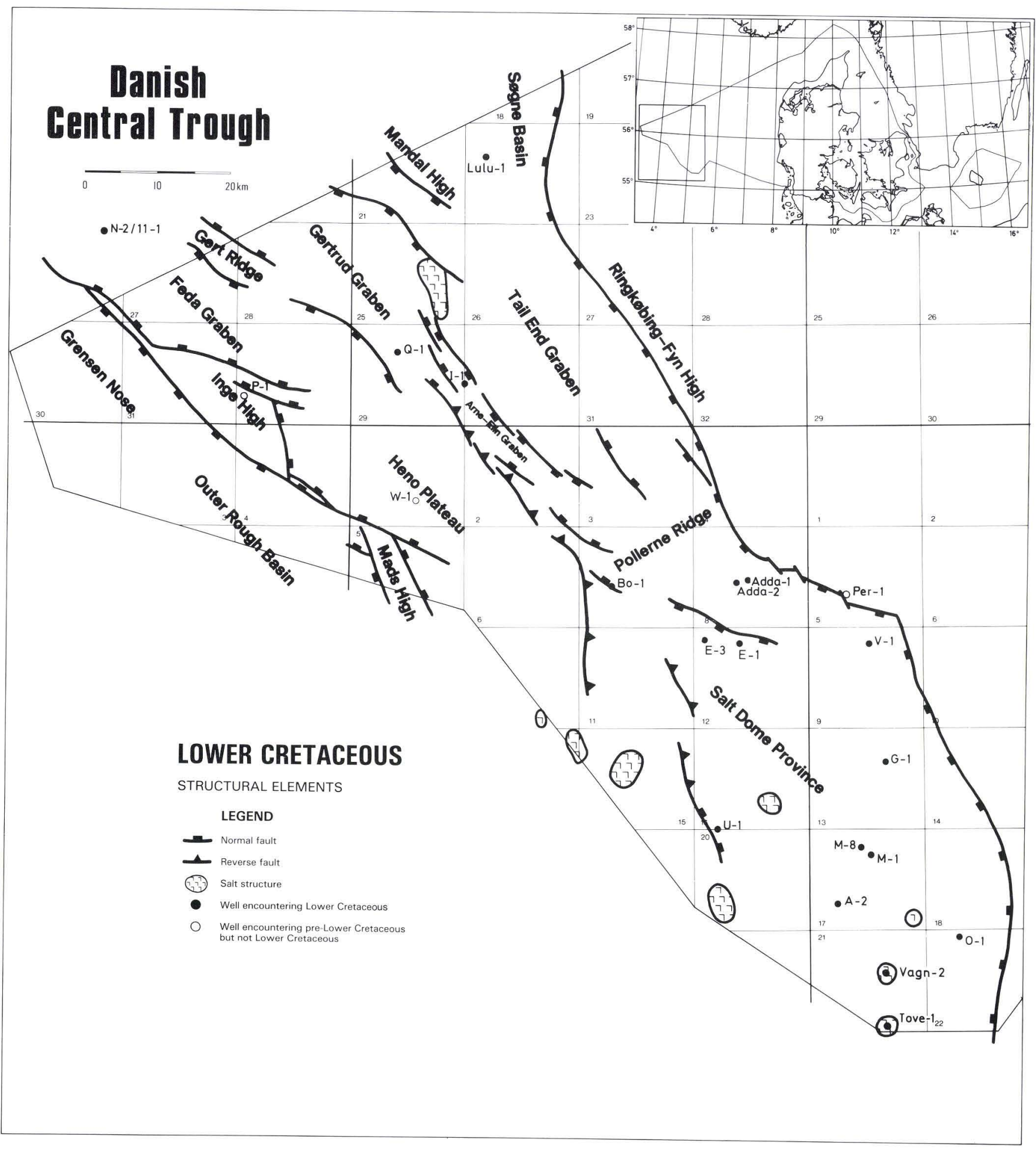

Fig. 2: Early Cretaceous structural outline of the Danish Central Trough, including location of wells penetrating the Lower Cretaceous sequence (by Ole Valdemar Vejbak). 
Basin and in the Salt Dome Province (fig. 1). Core and log data indicate that a northern and a southern facies region existed during the Middle Jurassic suggesting differences in the environment of deposition (fig. 9). Active subsidence, relative to the stable areas in the western part of the Danish Central Trough, took place in the Søgne Basin - Tail End Graben trend and dissected the Mid North Sea High - Ringkøbing-Fyn High trend (Gowers \& Sæbøe 1985).
The entire Central Trough region was transgressed by rising sea level at the beginning of the Late Jurassic, although the Mandal, Inge and Mads Highs probably remained emersed (fig. 1). Sedimentation of clay with minor influx of coarser-grained material dominated. A change in organic matter types, i.e. from vitrinite and inertinite in the Oxfordian clays to liptinite, mainly alginite, in the Kimmeridgian and Volgian clays, indicates a shift from nearshore to more open marine con-

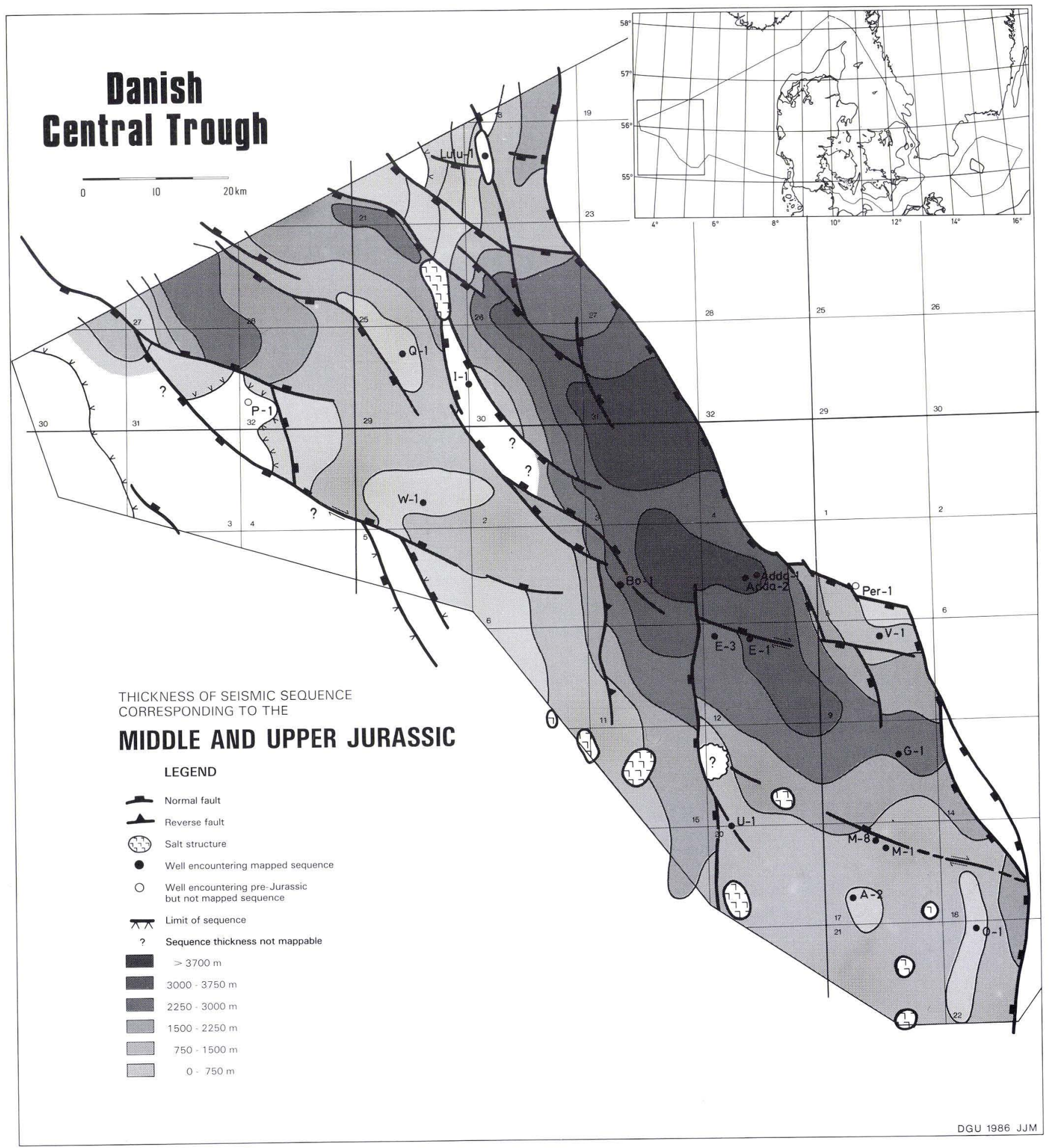

Fig. 3: Thickness and distribution of the seismic sequence between the Mid and Late Cimmerian Unconformities (by Jens Jørgen Mфller). 
ditions during the Late Jurassic (Lindgreen et al. 1982). Sand deposited in a near coastal environment is known from the Heno Plateau and indicates erosion of the Inge and Mads Highs. Along the fault zone bordering the Ringkøbing-Fyn High, sand deposited by gravity flows has been drilled in the $\mathrm{V}-1$ well. At the beginning of the Late Jurassic the tectonic pattern changed significantly. The Søgne Basin became relatively inactive, whereas the Feda Graben started to subside (fig. 1). The Outer Rough Basin also subsided, so that the Inge and Mads Highs became isolated from the Mid North Sea High. The subsidence of the Feda Graben and the Tail End Graben was asymmetric with the strongest subsidence along the bordering faults towards the SW and NE respectively (Gowers \& Sæbøe 1985). The main subsidence phase of the Central Trough took place during the Late Jurassic with deposition of more than $3000 \mathrm{~m}$ of sediments. This pattern of subsidence is explained by right lateral wrench movements along a WNW-ESE fault trend creating pull-apart basins (Gowers \& Sæbøe 1985, Møller 1986, see also fig. 3).

Differential subsidence of basins and grabens of the Central Trough continued during the Early Cretaceous and resulted in the development of small basins having local depocentres (Gowers \& Sæbøe 1985). In the Danish Central Trough several such basins can be recognized (fig. 2 and Vejbæk 1986). The subsidence which culminated during the Volgian continued at a decreased rate during the Ryazanian to mid Hauterivian and resulted in the deposition of up to $900 \mathrm{~m}$ of sedi- ments (fig. 25). At mid Hauterivian time subsidence further decreased and contemporaneously basin inversion was initiated (Vejbæk 1986). Consequently formations of mid Hauterivian to Albian age (fig. 4) are often absent in inverted areas (e.g. The Salt Dome Province) and the thickness of the sequence only reaches a maximum of c. $300 \mathrm{~m}$ (fig. 31). During the latter period differential subsidence gradually ceased and gave way for the regional subsidence characteristic of the Late Cretaceous (Vejbæk 1986).

In general terms the Early Cretaceous period can be regarded as a time of transition between the Jurassic, where clastic deposition was dominant, and the Late Cretaceous, which was totally dominated by pelagic carbonate deposition.

The lateral facies distribution in the Early Cretaceous basins may be explained as the result of an interaction between a relatively "constant" pelagic carbonate production and sedimentation and a varying input of clastic material, which again was dependent on the tectonic setting of the area in question and the type of source area available for erosion. The vertical changes in facies, towards more calcareous sediments upwards through the Cromer Knoll Group, are explained as the result of a decreasing input of clastic material owing to the general trend of a rising sea level (e.g. Vail \& Todd 1981, Rawson \& Riley 1982), to some degree possibly followed by an increase in pelagic carbonate production. As a result, regionally correlatable basin facies and local basin margin facies were developed. 


\section{Lithostratigraphy}

LOWER CRETACEOUS LITHOSTRATIGRAPHIC CORRELATION CHART

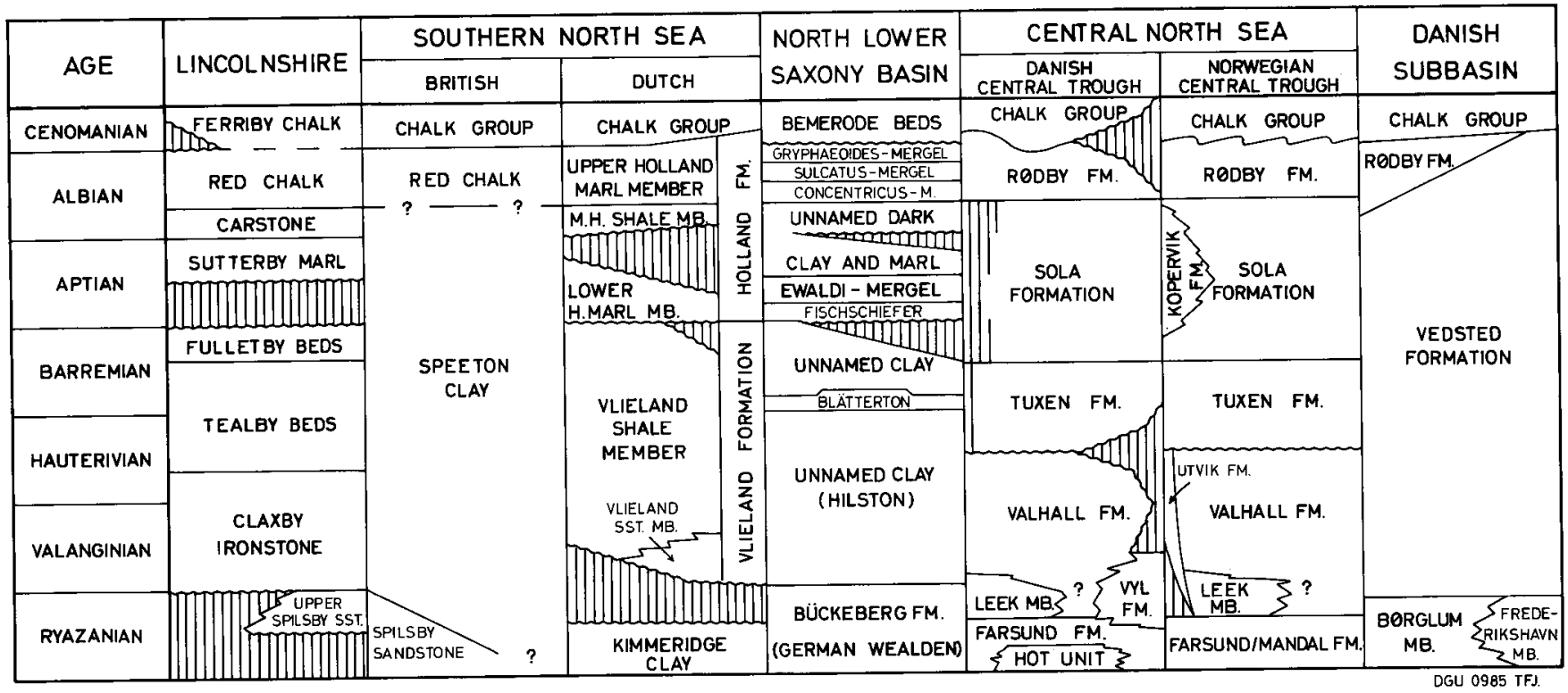

Fig. 4: Lower Cretaceous lithostratigraphic correlation chart (compiled and modified from Larsen (1966), Schott (1969), Kemper (1973a \& b), Rhys (1974), Rawson et al. (1977), Deegan \& Scull (1977), Wood \& Smith (1978), Kemper (1979), NAM \& RGD (1980), Crittenden (1982), Hesjedal \& Hamar (1983), Vollset \& Doré (1984), Edwin Kemper (pers. comm. 1985)).

JURASSIC LITHOSTRATIGRAPHIC CORRELATION CHART

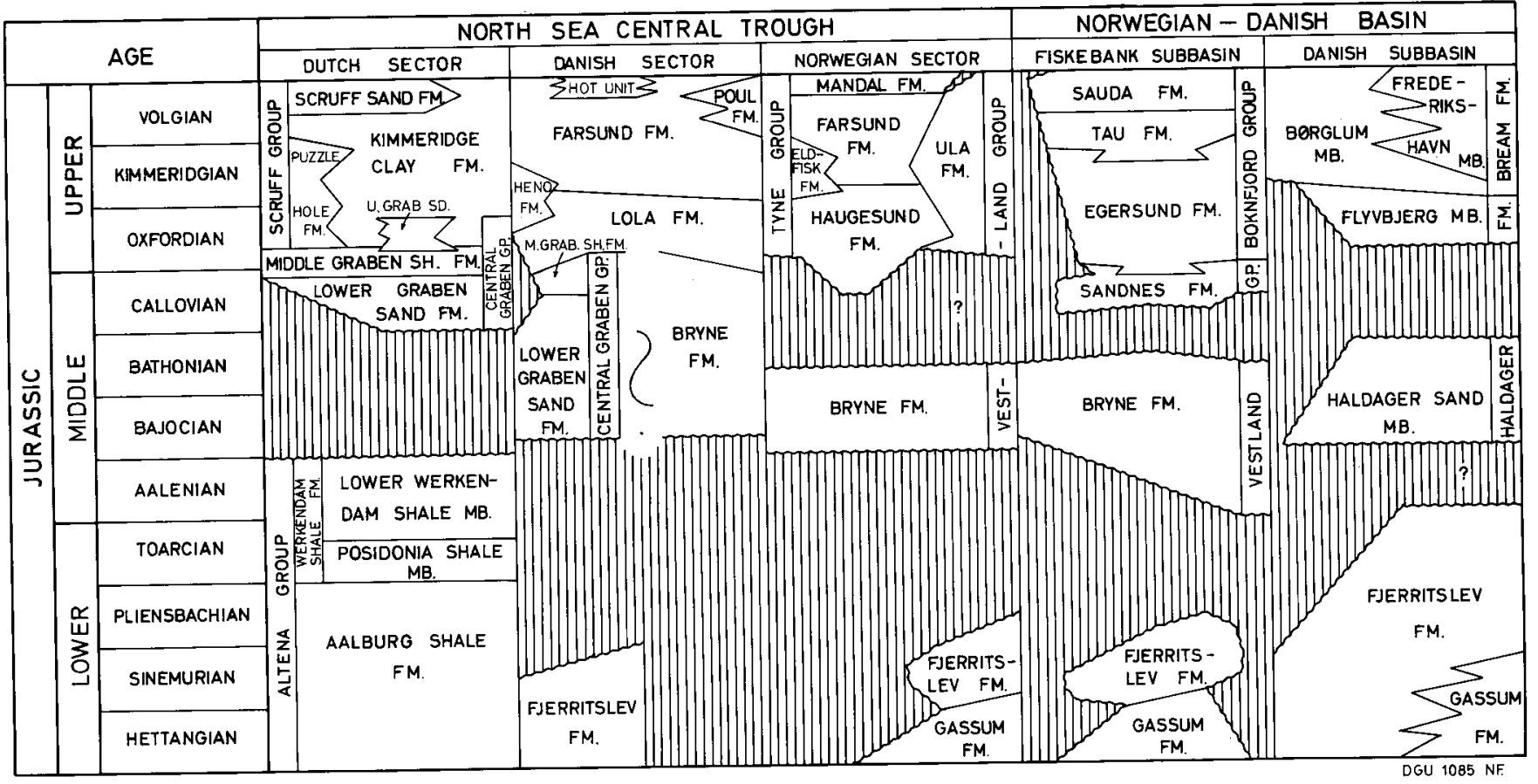

Fig. 5: Jurassic lithostratigraphic correlation chart (compiled on the basis of Bertelsen (1978), Michelsen (1978a), NAM \& RGD (1980), Herngreen \& de Boer (1984), Michelsen et al. (1984), Vollset \& Doré (1984)). 
Since Deegan \& Scull (1977) presented the first lithostratigraphic subdivision of the Jurassic sequence in the central North Sea, the amount of released well data has increased rapidly. Thus a more detailed and differentiated lithostratigrahpic scheme can now be created. Informal lithostratigraphic units of the Danish Jurassic sequence were described by Koch et al. 1982, as none of the formations described by Deegan \& Scull (1977) were usable. However, since then, Hamar et al. (1983) and Vollset \& Doré (1984) have published a revised lithostratigraphy for the Norwegian North Sea. To a certain degree this new subdivision is applicable to the Danish region, so that some of the newly established Norwegian formations have been extended into the Danish Central Trough (see fig. 5).

On line with Vollset \& Doré (1984) and Doré et al. (1985) we abandon the name "Kimmeridge Clay Formation" in the Danish area for reasons discussed in these papers.

Deegan \& Scull (1977) realized that their subdivision of the Cromer Knoll Group certainly was too simple but owing to data restrictions they were not able to introduce other formations or members. Further exploration in the North Sea has enhanced the need for a revision of the Lower Cretaceous lithostratigraphy. Informal lithostratigraphic units have been introduced by Hansen \& Buch (1982) and Hesjedal \& Hamar (1983) for the Danish and Norwegian parts of the Central Trough.

The present paper introduces a formal detailed subdivision of the Lower Cretaceous sequence of the Danish Central Trough, a subdivision which appears to be applicable in adjacent sectors.

Diagrams presenting the lithostratigraphies of various authors and areas are shown in figs. 4 and 5.

\section{Fjerritslev Formation}

The formation was established by Larsen (1966) and later revised and subdivided by Michelsen (1978a) into four members (F-I, F-II, F-III and F-IV). The type well (Fjerritslev-2) is situated in northern Jylland in the northwestern part of the Danish Subbasin, in which the formation is widely distributed.

The Lower Jurassic claystones in the Danish Central Trough are referred to the Fjerritslev Formation and are regarded as a remnant of a presumed Lower Jurassic cover existing prior to the early Middle Jurassic (Mid Cimmerian) uplift and erosion.

The Fjerritslev Formation is equivalent to the Dunlin Group in the northern North Sea, see fig. 5 (Vollset \& Doré 1984).

\footnotetext{
2 DGU Serie A: Jurassic
}

\section{Name:}

Named by Larsen (1966) after Fjerritslev, a village in northern Jylland.

\section{Well type section:}

The Fjerritslev-2 well in northern Jylland from $1322 \mathrm{~m}$ to $2233 \mathrm{~m}$ b.KB (Michelsen 1978a, fig. 6a - b).

\section{Well reference section:}

The Danish O-1 well from $9830 \mathrm{ft}$. to $10347 \mathrm{ft}$. b.KB, 2968-3126 m b.MSL (fig. 6).

\section{Thickness:}

The thickness of the Fjerritslev Formation is $158 \mathrm{~m}$ (O-1), $93 \mathrm{~m}(\mathrm{M}-8)$ and $46 \mathrm{~m}(\mathrm{U}-1)$, - see fig. 7.

In the Danish Central Trough the formation is rather thin in comparison to the type section. This is partly due to the early Middle Jurassic erosion of the top of the formation.

$0-1$

FJERRITSLEV FORMATION, REFERENCE SECTION

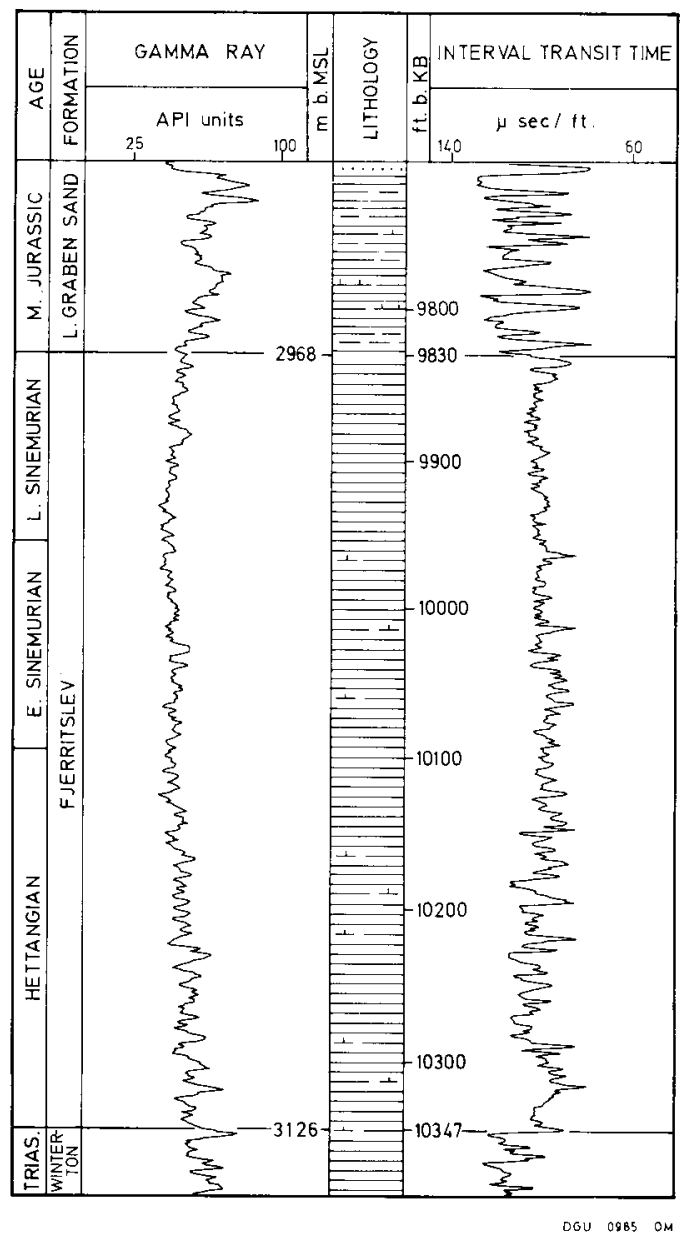

Fig. 6: The Danish $0-1$ well. Reference section for the Fjerritslev Formation (legend fig. 33). 
IN THE DANISH CENTRAL TROUGH
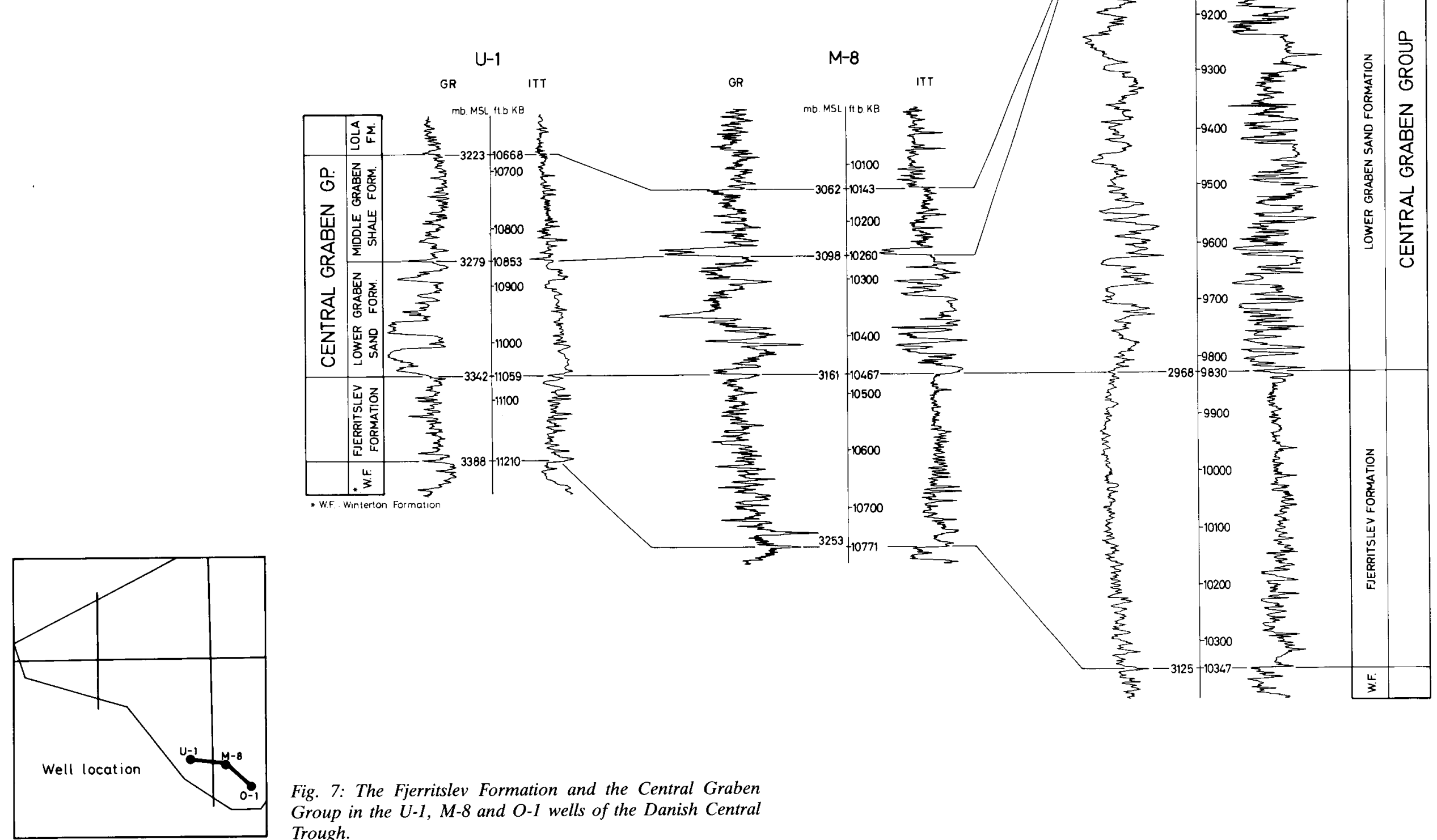

Fig. 7: The Fjerritslev Formation and the Central Graben

Group in the U-1,M-8 and O-1 wells of the Danish Central

Trough. 


\section{Lithology:}

The formation consists mainly of dark grey, slightly calcareous, silty, sometimes fissile claystones with pyrite. Downwards the claystones are interbedded with thin, light grey, silty, calcareous claystones and soft marlstones.

\section{Log characteristics:}

The formation is characterized by regular high gamma ray readings and a relatively regular sonic velocity pattern. Downwards the sonic velocity becomes more irregular, reflecting more abundant occurrence of thin, soft marls and hard, silty claystones.

\section{Boundaries:}

The lower boundary of the Fjerritslev Formation is the contact to the underlying Winterton Formation (Rhys 1974 and Jacobsen 1982) which is characterized by a very low sonic velocity and a high gamma radiation. This boundary is thus defined by marked changes both in the gamma ray readings and the sonic velocity.

The Fjerritslev Formation is unconformably overlain by the Lower Graben Sand Formation which is characterized by a very irregular sonic velocity pattern.

\section{Distribution:}

Seismically the formation has not yet been mapped. It has been penetrated by wells situated in the southern part of the Danish sector.

\section{Geological age:}

On the basis of ostracods the formation is dated to the Hettangian-Sinemurian in the three wells (Michelsen 1978a).

\section{Subdivision:}

On the basis of log analyses the formation may be subdivided into two units as described in Michelsen (1978b), and not into three units as mentioned in Koch et al. (1982). The ages of the two units, and partly the lithologies, make a correlation to the member F-Ia-b of the Danish Subbasin possible (Michelsen 1978b, pp. 81-82).

\section{Depositional environment:}

The fine-grained sediments suggest that the formation was deposited in a low energy marine environment.
The upwards decreasing occurrence of silt- and marlstone beds points to a relative rise of sea level.

\section{Bryne Formation}

The Brync Formation is broadly equivalent to the Haldager Sand of the Haldager Formation in the Danish Subbasin (Michelsen 1978a), to the Sleipner Formation of the southern Viking Graben (Vollset \& Doré 1984) and to the Lower Graben Sand Formation of the southern North Sea, see fig. 5 (NAM \& RGD 1980).

Name:

Named by Vollset \& Doré (1984) after a town in southwestern Norway.

\section{Well type section:}

The Norwegian 9/4-3 well from $2507.5 \mathrm{~m}$ to $2613 \mathrm{~m}$ b.KB (Vollset \& Doré 1984, fig. 29).

\section{Well reference section:}

The Danish Lulu-1 well from $11712 \mathrm{ft}$. to $12134 \mathrm{ft}$. b.KB, 3540-3669 m b.MSL (fig. 8).

\section{Thickness:}

The formation has a thickness of $129 \mathrm{~m}$ in Lulu-1 which is the only released well penetrating it in Danish waters. Consideration of structural evolution and sedimentary history in the area together with comparison to Norwegian wells make it likely, that the thickness of the formation in the Danish sector may vary significantly above as well as below the thickness in Lulu-1.

\section{Lithology:}

The Bryne Formation makes up a series of sandstones intensely interbedded with siltstones and claystones. In places the interbedding takes the character of a heterolith. Scattered coal beds up to $0.5 \mathrm{~m}$ thick occur and all rock types contain coal fragments varying in size from less than $1 \mathrm{~mm}$ up to several $\mathrm{cm}$. The sandstones are mostly fine-grained but medium-grained and occasional coarse-grained sandstones do occur. They are varyingly grey, occasionally with shades of brown. Parallel lamination and small- and large-scale cross-lamination are important structures. Bioturbation is mostly absent but is very common in places. Rootlets occur, sometimes below coal beds. Generally, the sandstones 
LULU -1

BRYNE FORMATION, REFERENCE SECTION

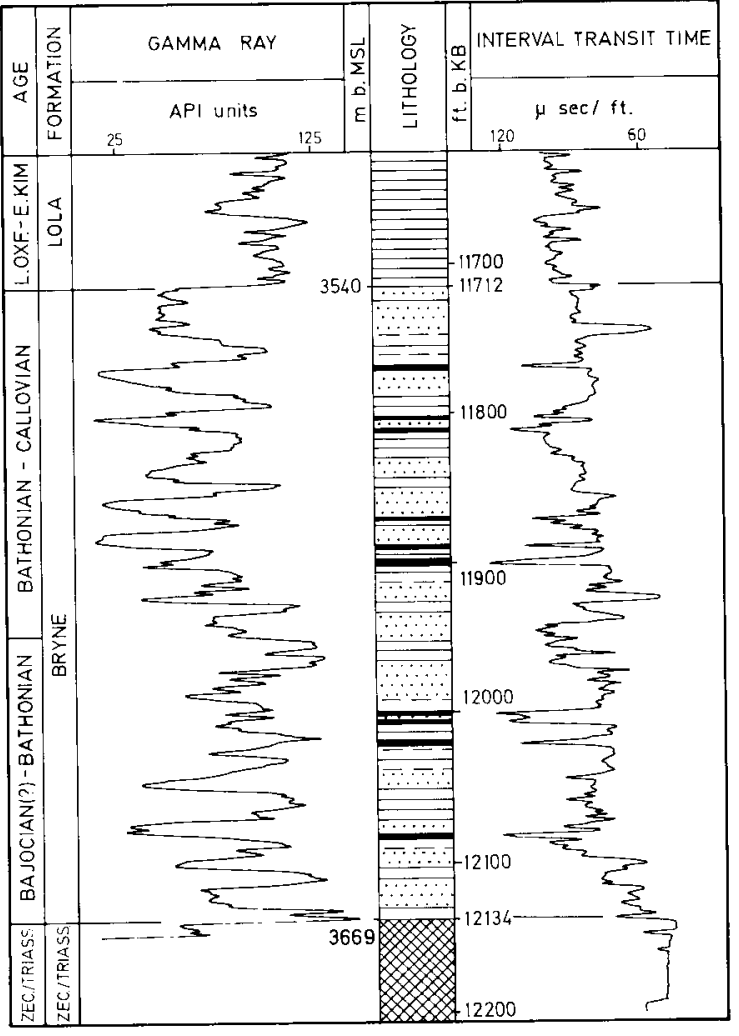

DGU 0985

Fig. 8: The Danish Lulu-1 well. Reference section for the Bryne Formation (legend fig. 33).

and siltstones are fairly well consolidated. The claystones are dark brown to dark grey, micaceous and hard to moderately hard.

\section{Log characteristics:}

The rapidly changing lithology of the formation is reflected in the log motifs: The gamma ray radiation as well as the sonic velocity fluctuate with high gamma readings and low velocities in the claystones and low gamma readings and high velocities in the sandstones. Distinct peaks of low velocity show the presence of coal beds and peaks of high velocity reflect carbonate cementation of the sandstones.

\section{Boundaries:}

The Lulu-1 well was drilled on a salt structure where the Bryne Formation overlies evaporites of Permian or Triassic age. It is overlain by the Lola Formation. In the Danish sector away from the Lulu salt structure, the formation probably rests on Triassic sediments. However, rocks of greater age cannot be excluded. The formation is overlain by claystones belonging to the Lola Formation or the Farsund Formation.

\section{Distribution:}

The Bryne Formation is found in the northern part of the Tail End Graben, and according to Gowers \& Sæbøe (1985) in the Feda Graben region (fig. 9). Its extension to the south is questionable owing to lack of well control and to poor seismic resolution.

Age:

Palynological investigations in the Lulu-1 well refer the Bryne Formation to the Bathonian-Callovian with questionable Bajocian ages in the lower part of the sequence (Hoelstad 1986a).

\section{Depositional environment:}

Frandsen (1986) suggests that the Bryne Formation in the Lulu-1 well was deposited during a regional transgression. The major part of the sequence was deposited in a delta plain environment whereas the uppermost beds are coastal lagoon and barrier island deposits.

\section{Central Graben Group}

Previously this unit was the informal J-2 unit (Koch et al. 1982). It is broadly equivalent to the Haldager Formation in the Danish Subbasin (Michelsen 1978a) and to the Vestland Group in the northern Central Trough and the Norwegian-Danish Basin, see fig. 5 (Vollset \& Doré 1984).

\section{Name:}

Named by NAM \& RGD (1980) after the Central Graben (Trough) of the North Sea.

\section{Type area:}

The southern part of the Central Trough in Dutch waters.

\section{Thickness:}

In released wells in Danish waters the thickness of the group varies between $40 \mathrm{~m}$ and $237 \mathrm{~m}$.

\section{Lithology:}

The lower part of the Central Graben Group is characterized by rather thick sandy sequences with interca- 
lations of silt- and claystone and occasional thin coal beds. The upper part contains claystones, siltstones and in most wells coal beds that may be rather thick.

\section{Boundaries:}

In Danish waters the Central Graben Group is found above the Mid Cimmerian Unconformity, which is marked by a large hiatus at top of the clayey Fjerritslev
Formation. The group is overlain by the clayey Lola Formation.

\section{Distribution:}

The Central Graben Group is found in the Salt Dome Province of the Danish Central Trough (fig. 9). Its extension to the north is questionable owing to lack of well control and to poor seismic resolution.

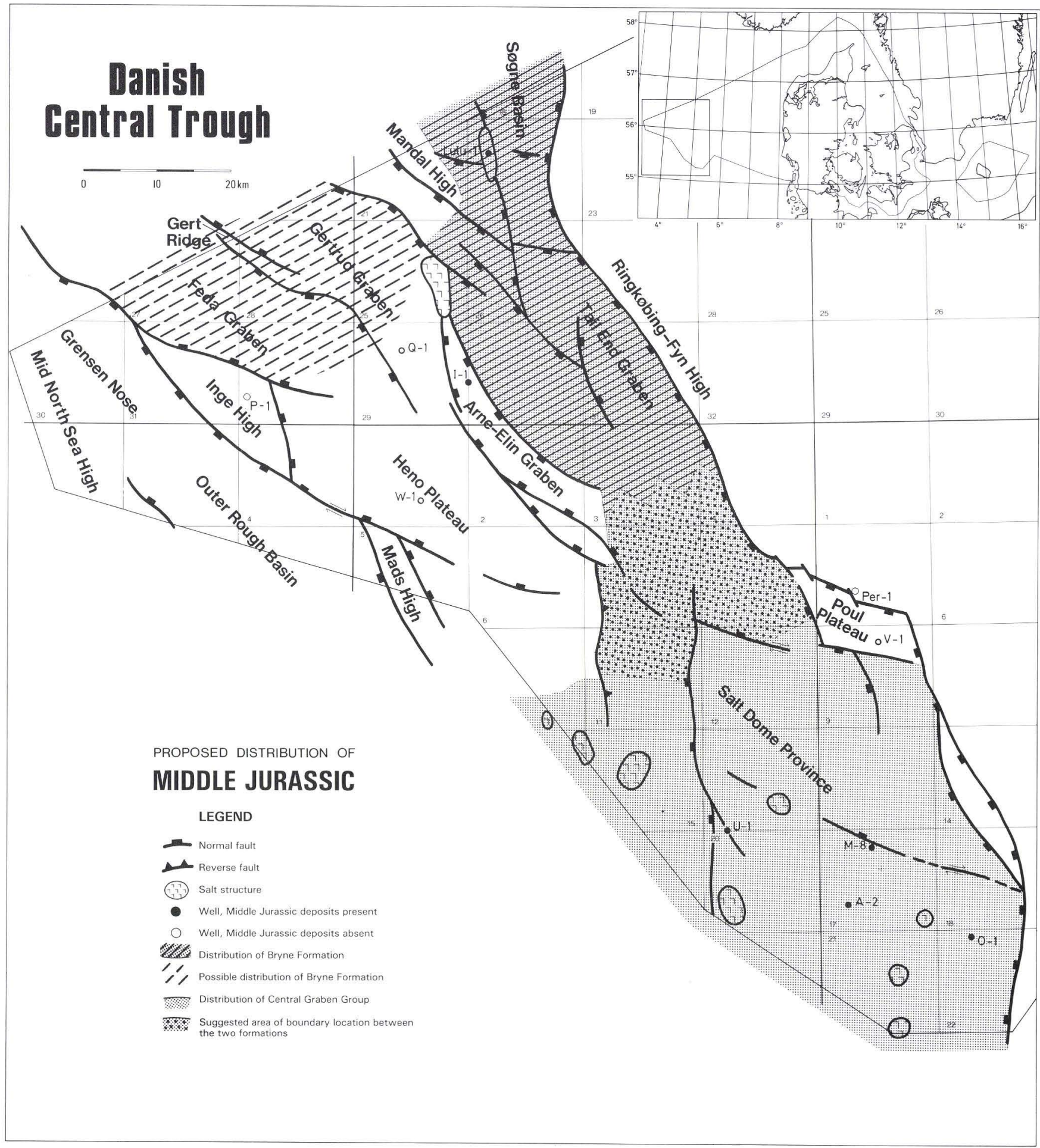

Fig. 9: Map of the distribution of the Middle Jurassic Bryne Formation and Central Graben Group. 
Age:

Palynostratigraphic investigations (Poulsen 1986, Hoelstad 1986b) show that the Central Graben Group in the Danish sector was probably deposited mainly during the Callovian but Bathonian and Bajocian ages are also reported.

\section{Subdivision:}

Two formations, the Lower Graben Sand Formation and the Middle Graben Shale Formation, are recognized within the Central Graben Group in Danish waters.

\section{Remark on stratigraphic nomenclature:}

As will appear from the account above, it is proposed that the stratigraphic nomenclature used in the Dutch sector be extended into the Danish sector. However, as the Dutch terms are formally incorrect, we suggest them to be changed.

\section{Lower Graben Sand Formation}

The formation was previously the lower member of the informal J-2 unit (Koch et al. 1982). It is broadly equivalent to the Haldager Sand of the Haldager Formation in the Danish Subbasin (Michelsen 1978a) and to the Bryne Formation in the northern Central Trough and the Norwegian-Danish Basin, see fig. 5 (Vollset \& Doré 1984).

\section{Name:}

Named by NAM \& RGD (1980) after the Central Graben (Trough) of the North Sea.

\section{Well type section:}

The Dutch F3-3 well from $3090 \mathrm{~m}$ to $3652 \mathrm{~m} \mathrm{b.KB}$ (NAM \& RGD 1980, encl. 21).

\section{Well reference section:}

The Danish U-1 well from $10853 \mathrm{ft}$. to $11059 \mathrm{ft}$. b.KB, 3279-3342 m b.MSL (fig. 10).
U-1

LOWER GRABEN SAND FORMATION, REFERENCE SECTION

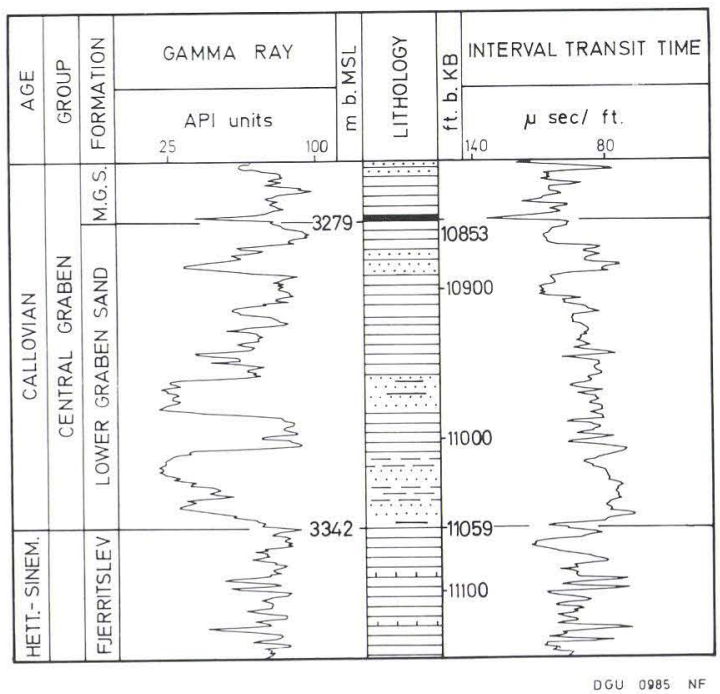

Fig. 10: The Danish U-1 well. Reference section for the Lower Graben Sand Formation (legend fig. 33).

\section{Thickness:}

In released wells in the Danish sector the thickness of the formation ranges from $24 \mathrm{~m}$ to $237 \mathrm{~m}$.

\section{Lithology:}

The Lower Graben Sand Formation is characterized by rather thick sandstone units (thickness up to about 10 $\mathrm{m}$ ) interbedded with claystones, siltstones and heteroliths. Thin coal beds are intercalated towards the east. All rock types contain coal pieces varying in size from less than $1 \mathrm{~mm}$ to more than $1 \mathrm{~cm}$, some identifiable as leaf fragments. The sandstones are mostly fine-grained but medium-grained sandstones occur and even coarsegrained sandstones and gravel are found. The thick sandstones may be silty in the upper parts. Greyish and brownish colours characterize the sandstones and siltstones. No cores are available from the formation but sidewall cores indicate the presence of parallel lamination and cross-lamination. Generally, the sandstones and siltstones are rather weakly consolidated - to judge from sidewall cores. The claystones are generally brownish black, slightly shaly, varyingly micaceous and fairly well consolidated.

\section{Log characteristics:}

Generally, the log pattern of the formation fluctuates strongly in response to the changing lithology. The thick sandstones impart a somewhat blocky character 
to parts of the sequence with weak gamma ray radiations and high sonic velocities corresponding to the sandstones interrupted by thin intervals of high gamma readings and low velocities showing the presence of claystones. In other parts of the sequence a more serrated log pattern reflects the rapid alternation of lithologies.

\section{Boundaries:}

The Lower Graben Sand Formation in the Danish sector overlies the dark grey claystones of the Fjerritslev Formation except in the A-2 well where it rests on reddish claystones probably of Triassic age. Two criteria define the lower boundary of the formation: 1 - a change upwards from relatively gently fluctuating log readings to readings that fluctuate very strongly, and/or 2 - the first upward occurrence of sandstone.

The formation is overlain by dark claystones belonging to the Middle Graben Shale Formation. Generally, there is a change to slightly higher gamma readings and slightly lower sonic velocities in the overlying formation. The upper boundary is placed at the base of a prominent coal bed (in the M- 8 and $U-1$ wells) or at the top of a thick sandstone bed (A-2). However, in the O-1 well the formation is overlain by the Lola Formation. The absence of the Middle Graben Shale Formation in this well is supposed to be due to faulting.

\section{Distribution:}

The Lower Graben Sand Formation is found in the Salt Dome Province of the Danish Central Trough (fig. 9). Its extension to the north is questionable owing to lack of well control and to poor seismic resolution. To the south, the formation is assumed to pass laterally into the Lower Graben Sand Formation of the Dutch sector.

Age:

Most of the Lower Graben Sand Formation was probably deposited during the Callovian as shown by palynostratigraphic investigations (Poulsen 1986, Hoelstad 1986b) but Bathonian and Bajocian ages are reported from the formation.

\section{Depositional environment:}

On the basis of lithological criteria and palynofacies investigations it is concluded that the Lower Graben Sand Formation was deposited in a marginal marine environment with strong fluvial influence, probably a delta with lagoons and interdistributary bays (Frandsen et al. 1985, Hoelstad 1986b).

\section{Middle Graben Shale Formation}

Previously this unit was the upper member of the informal J-2 unit (Koch et al. 1982). It is broadly equivalent to the Flyvbjerg Member of the Haldager Formation in the Danish Subbasin (Michelsen 1978a) and to the Sandnes Formation in the northern Central Trough and the Norwegian-Danish Basin, see fig. 5 (Vollset \& Doré 1984).

Name:

Named by NAM \& RGD (1980) after the Central Graben (Trough) of the North Sea.

Well type section:

The Dutch F3-3 well from $2670 \mathrm{~m}$ to $3090 \mathrm{~m} \mathrm{b.KB}$ (NAM \& RGD 1980, encl. 21).

\section{Well reference section:}

The Danish U-1 well from $10668 \mathrm{ft}$. to $10853 \mathrm{ft}$. b.KB, 3223-3279 m b.MSL (fig. 11).

\section{Thickness:}

In released wells in the Danish sector the thickness of the formation varies from $15 \mathrm{~m}$ to $56 \mathrm{~m}$.

\section{$U-1$}

MIDDLE GRABEN SHALE FORMATION, REFERENCE SECTION

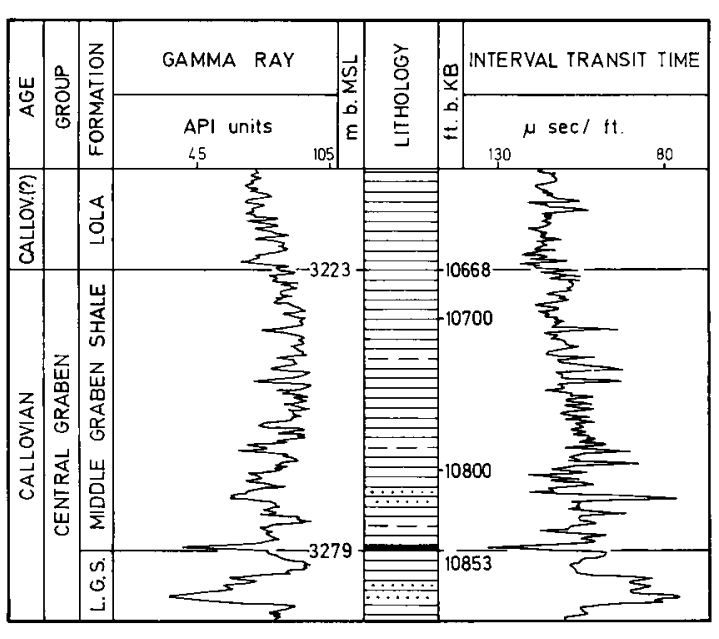

DGU $0985 \mathrm{NF}$

Fig. 11: The Danish U-1 well. Reference section for the Middle Graben Shale Formation (legend fig. 33). 


\section{Lithology:}

The Middle Graben Shale Formation comprises claystones interbedded with siltstones and very scattered sandstone beds. A few coal beds, at places attaining thicknesses of up to several metres, may be intercalated in the lower part of the formation. The claystones are dark brownish grey and contain some microlignite. They are moderately hard to hard and slightly shaly.

\section{Log characteristics:}

The predominance of claystone in the formation is reflected by relatively strong gamma ray radiations and low sonic velocities in comparison to the underlying Lower Graben Sand Formation. In addition, the log pattern is less fluctuating, a result of more uniform lithologies. Very distinct peaks of low gamma readings and low velocities show the presence of the coal beds. This feature appears distinctly characteristic for the Middle Jurassic formations (the Central Graben Group) in the southern part of the Central Trough (including the Dutch sector) in contrast to the formations (the Vestland Group) in the northern part of the trough (including the Norwegian sector). In this northern region, coal beds also result in low sonic velocities but gamma ray responses are absent or almost so.

\section{Boundaries:}

The Middle Graben Shale Formation in the Danish sector overlies the Lower Graben Sand Formation. The lower boundary is placed at the base of a prominent coal bed (in the M-8 and U-1 wells) or at the top of a thick sandstone bed (A-2).

The formation is overlain by claystones of the Lola Formation. This formation is characterized primarily by lower sonic velocities and the boundary between the formations is placed at a sudden, fairly large drop in velocity when passing from the Middle Graben Shale Formation to the Lola Formation.

\section{Distribution:}

The distribution of the Middle Graben Shale Formation follows that of the Lower Graben Sand Formation, except that it seems to be absent in the $\mathrm{O}-1$ well close to the Ringk øbing-Fyn High. This absence is possibly due to faulting, as a normal fault may be present just above the top of the formation in the O-1 well.
Age:

Palynostratigraphic investigations (Poulsen 1986, Hoelstad 1986b) show that the Middle Graben Shale Formation in the Danish sector was deposited during the Callovian.

\section{Depositional environment:}

The clayey, coal-bearing sediments of the Middle Graben Shale Formation were deposited in swampy environments probably in interdistributary bays or in coastal lagoons.

\section{Lola Formation (new formation)}

Previously the formation was the informal J-3 unit (Koch et al. 1982). It is time-equivalent to the lower part of the so-called Kimmeridge Clay Formation (Rhys 1974, NAM \& RGD 1980), and to the Haugesund Formation, see fig. 5 (Vollset \& Doré 1984).

Name:

From the Lola structure in the Danish Central Trough (blocks 5504/16 and 20) on which the U-1 well has been drilled.

\section{Well type section:}

The Danish U-1 well from $9555 \mathrm{ft}$. to $10668 \mathrm{ft}$. b.KB, 2884-3223 m b.MSL (fig. 12).

\section{Well reference section:}

The Danish M-8 well from $8951 \mathrm{ft}$. to $10143 \mathrm{ft}$. b.KB, 2699-3062 m b.MSL (fig. 13).

\section{Thickness:}

On the basis of seismic data, the greatest thicknesses are expected to be present in the Tail End Graben and its continuation southwards into the Salt Dome Province. The maximum thickness is approximately 1000 $\mathrm{m}$. In the southern part of the Salt Dome Province, the thickness is c. $200 \mathrm{~m}$ (see fig. 15). 
U-1

LOLA FORMATION, TYPE SECTION

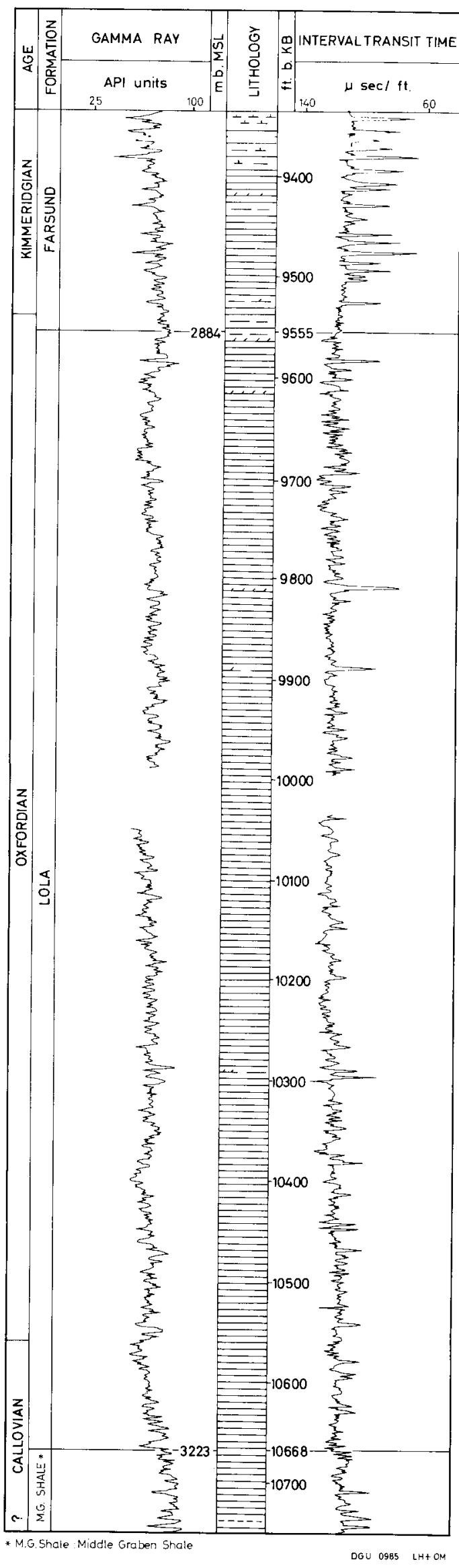

Fig. 12: The Danish U-1 well. Type section for the Lola Formation (legend fig. 33).

\section{Lithology:}

The formation consists of dark olive grey to medium grey claystone, slightly calcareous, with microlignite. The organic material is mainly of terrestrial origin (vitrinite and inertinite) and the total organic carbon content is around one percent (Thomsen et al. 1983).

\section{Log characteristics:}

The formation is characterized by fairly constant, high gamma ray readings and relatively low sonic velocities. A few high velocity peaks corresponding to dolomite or limestone beds may occur (figs. 13 and 14).

\section{Boundaries:}

The formation overlies the Central Graben Group in the southern parts of the Danish Central Trough. On the Heno Plateau and on local highs, the formation rests unconformably on Triassic or older strata. The lower boundary with the Central Graben Group is placed at a sudden, fairly large drop in sonic velocity where passing from the Central Graben Group to the Lola Formation (fig. 12). The boundary with the overlying Farsund Formation is defined above a velocity minimum, and above the boundary follows a general increase in velocity. Furthermore, the boundary is often located within a gamma ray maximum (fig. 13). In the Q-1 well the formation is overlain by the sanddominated sequence referred to the Heno Formation.

\section{Distribution:}

The formation is present in the eastern and southern parts of the Central Trough, but absent or thin west of the Tail End Graben. It is assumed to continue southwards and to pass into the lower part of the so-called Kimmeridge Clay Formation as defined in the Dutch F3-3 well (NAM \& RGD 1980, encl. 22). The base of the formation is considered diachronous with younger ages southwards, as the base of the Kimmeridge Clay Formation in Dutch waters is of Late Oxfordian age. The northward extension as well as the relation to the more silty and sandy Haugesund Formation is not known owing to lack of data in the area. An uncertain interpretation leads to the conclusion that the Lola Formation is present in the Q-1 and Lulu-1 wells (see figs. 17 and 14).

Age:

Late Callovian - Oxfordian, locally Kimmeridgian, based on palynological investigations (Poulsen 1986). 


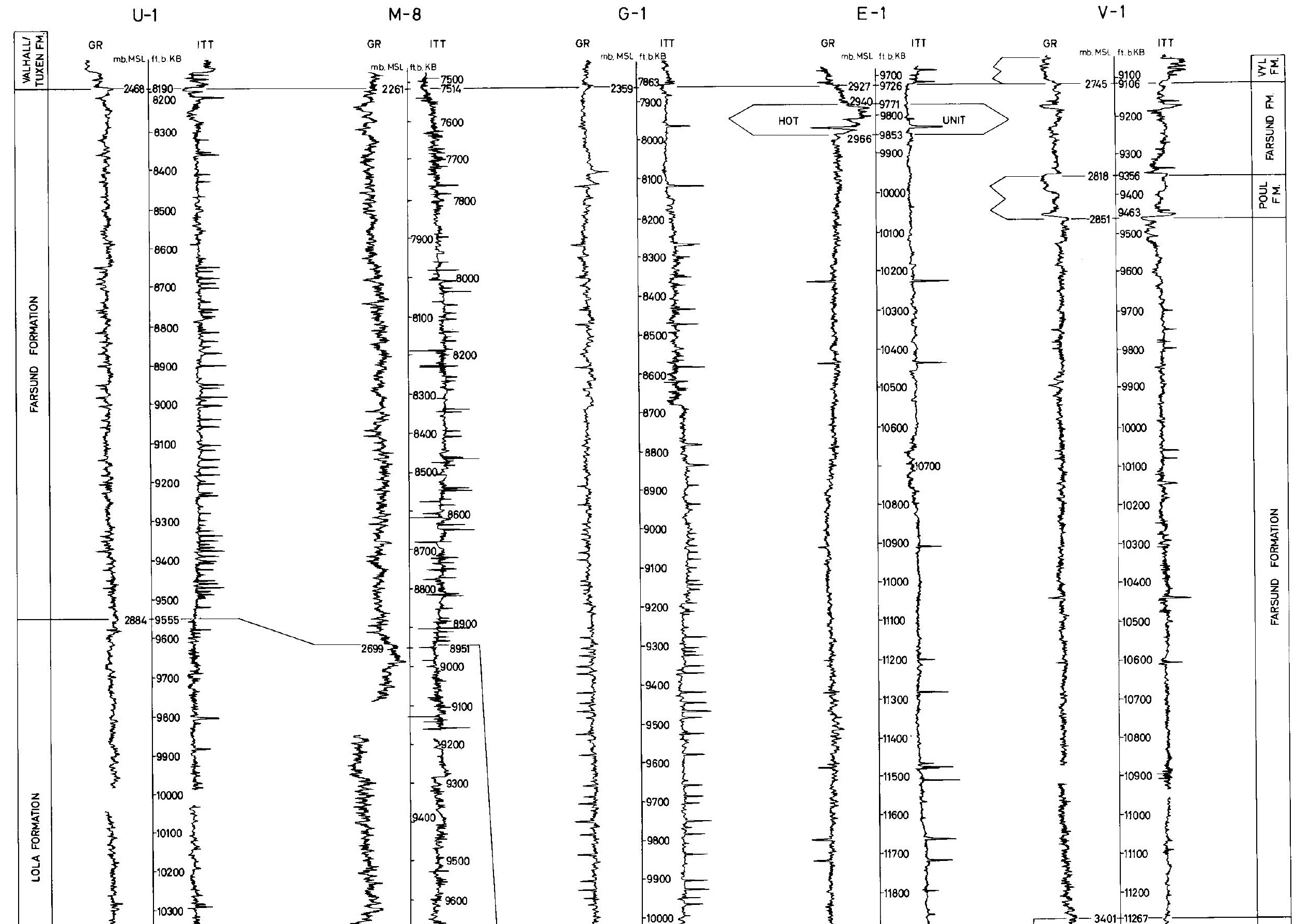


LOLA, FARSUND AND HENO FORMATIONS, AND HOT UNIT IN THE DANISH CENTRAL TROUGH

W-1

I-1

BO-1

GR ADDA-1

LULU-1

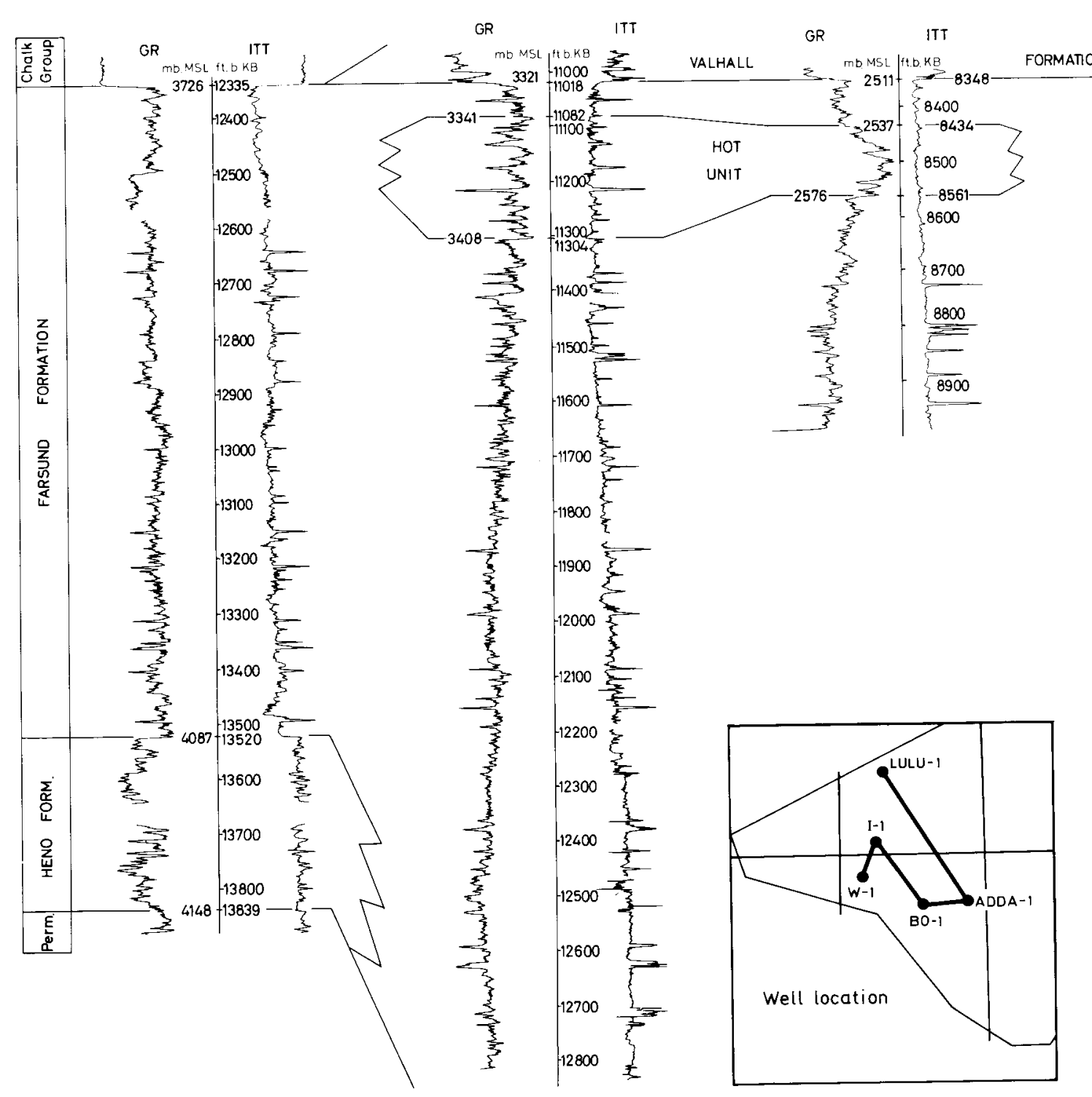

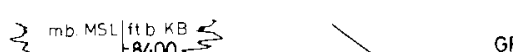

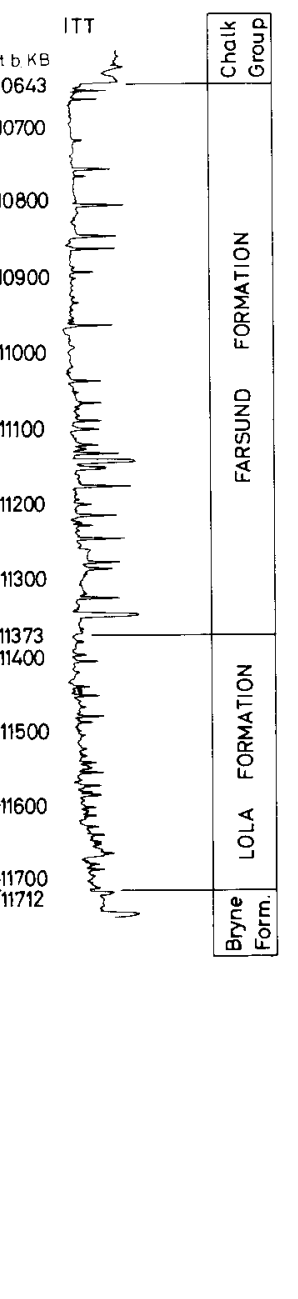

Fig. 14: The Lola, Farsund, and Heno Formations and the hot unit in the W-1, I-1, Bo-1, Adda-1 and Lulu-1 wells, the Danish Central Trough. 


\section{Depositional environment:}

The formation was deposited in a low energy marine environment. The nature of the organic matter suggests that the basin margin was not far away. The claystones represent open marine conditions that prevailed after the southward transgression that followed the early Middle Jurassic (Mid Cimmerian) uplift.

\section{Heno Formation (new formation)}

The formation has been penetrated in two Danish wells, the W-1 and Q-1, both situated east of the Inge High-Mads High trend. Previously it has been termed the W-1 unit (Koch et al. 1982). The formation may be equivalent to the Piper Formation of the northern North Sea (Deegan \& Scull 1977) and to the Fulmar Formation of the Central Trough (Johnson \& Stewart 1985).

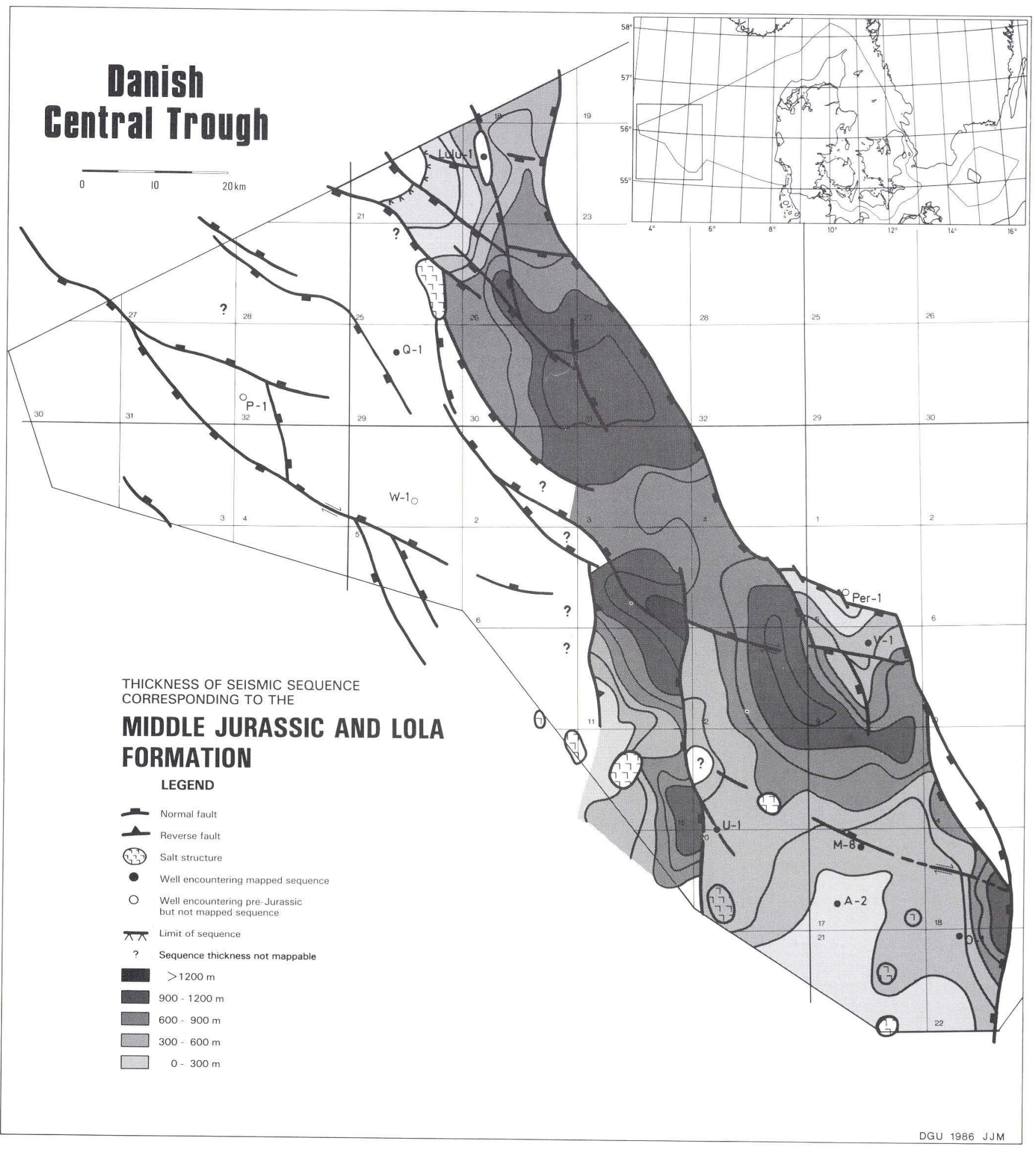

Fig. 15: Thickness and distribution of the seismic sequence corresponding to the Middle Jurassic and the Lola Formation (by Jens Jørgen Møller). 
W-1

HENO FORMATION, TYPE SECTION

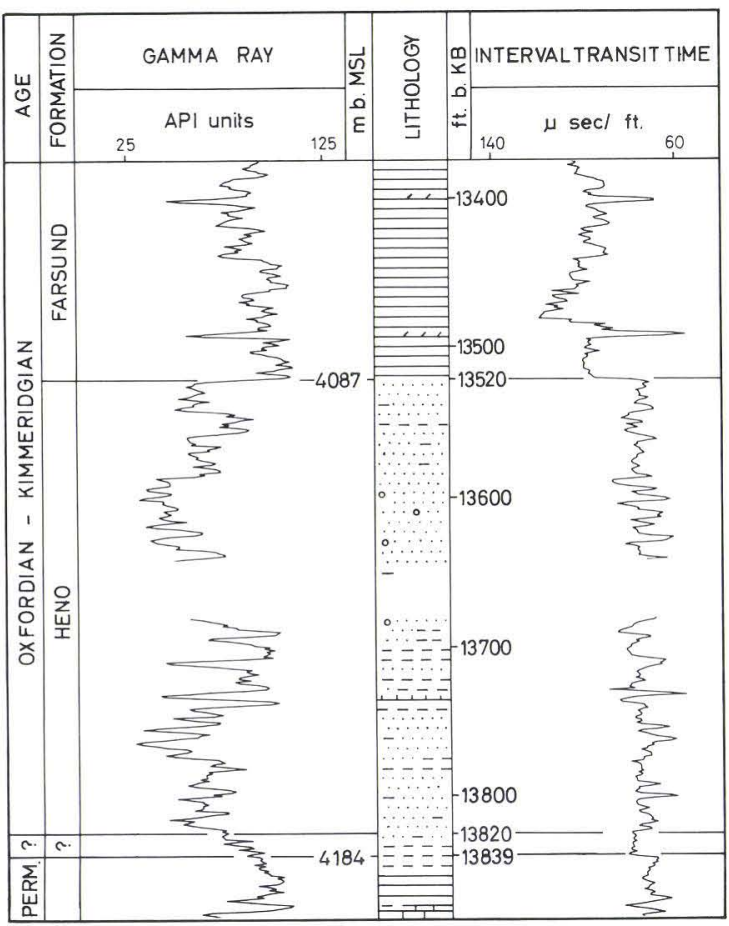

DGU $0985 \mathrm{LH}+\mathrm{OM}$

Fig. 16: The Danish W-1 well. Type section for the Heno Formation (legend fig. 33).

Name:

From the Heno structure in the Danish Central Trough (block 5504/1) on which the W-1 well has been drilled.

\section{Well type section:}

The Danish W-1 well from $13520 \mathrm{ft}$. to $13820 \mathrm{ft}$. b.KB, 4087-4178 m b.MSL (fig. 16).

\section{Well reference section:}

None at present.

\section{Thickness:}

$91 \mathrm{~m}$ in the type well and $54 \mathrm{~m}$ in the Q-1 well. The thickness may increase towards the highs to the west.

\section{Lithology:}

The formation consists of grey to white sandstones, and minor siltstones interbedded with claystones and heterolithic siltstones and claystones. The sandstones are

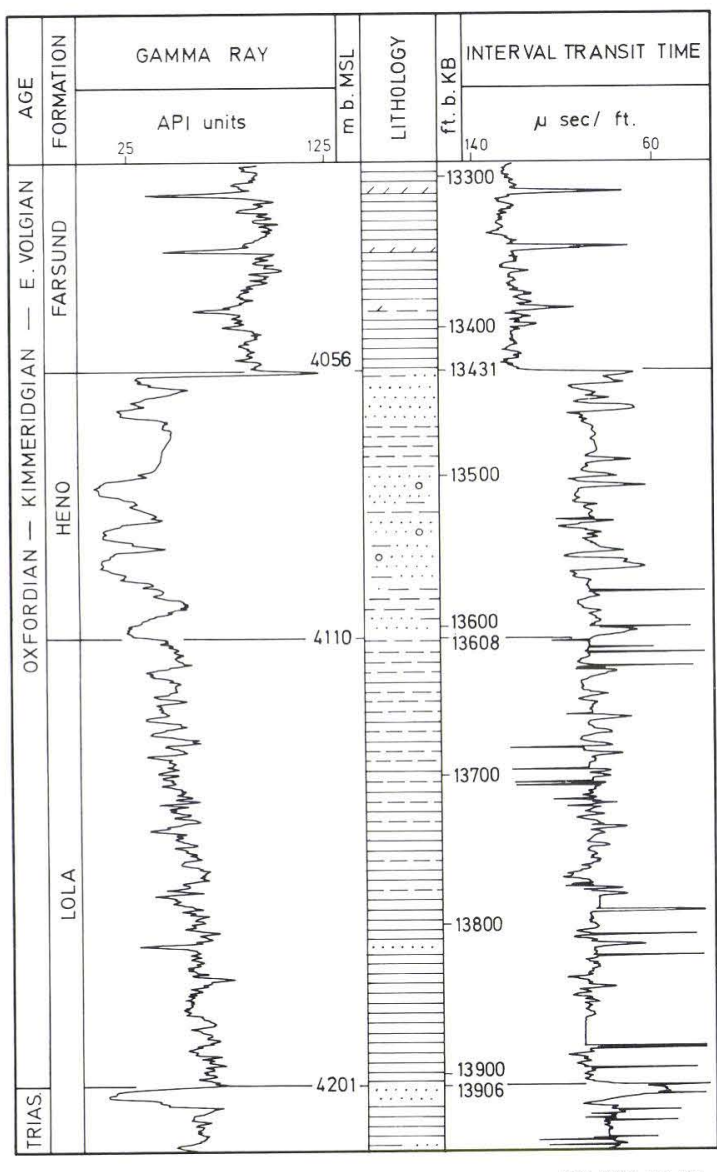

Fig. 17: The Lola and Heno Formations in the Danish Q-1 well (legend fig. 33).

predominantly fine-grained but medium- and coarsegrained sand occurs, and locally a conglomeratic sandstone is present. The claystones are light to dark grey, locally grading into or interbedded with argillaceous siltstone. The claystone and siltstone may contain carbonized plant remains.

\section{Log characteristics:}

The formation is characterized by low gamma ray values representing the sandstones, interrupted by higher values, reflecting the more fine-grained lithologies. The sonic log has intermediate values, with some peaks with higher velocity, reflecting carbonate cemented beds.

\section{Boundaries:}

In the type section, the formation rests on a claystone layer of unknown age, probably Late Jurassic. This 
claystone in turn overlies Triassic or Rotliegend redbeds. The lower boundary may therefore not be defined finally at present. It is suggested that the Heno Formation occurs in the Q-1 well. Here the base of the formation may be defined at the base of the lowermost sandstone bed in an overall upward coarsening sequence. The claystone below is of Late Jurassic age and is referred provisionally to the Lola Formation. The upper boundary is defined in the $\mathrm{W}-1$ well at a marked log shift to higher gamma ray values and lower sonic velocities, reflecting the clay-dominated Farsund Formation.

\section{Distribution:}

The formation is known from the two Danish wells lying east of the Inge High, which is believed to have acted as a source area for the sandstones. In agreement with this supposition, the thickest sequence is found in the W-1 well, situated closest to the high. However, the continuity of the sand body between the W-1 and Q-1 wells is not yet proved, since it is not known at what time the Feda Graben came into existence. A timeequivalent sandstone is found west of the Mads High, in the B-1 well in the German sector. Thus, the formation may occur along the margins of the highs.

Age:

A core taken in the middle of the formation in the W-1 well contains Middle-Late Oxfordian palynomorphs. The upper part of the formation is referred to the Kimmeridgian. It has not been possible to date the lowest part in W-1. In the Q-1 well, the sand as well as the upper part of the underlying Lola Formation are referred to the Kimmeridgian.

\section{Depositional environment:}

Interpretation of the core in $\mathrm{W}-1$ has been carried out by Koch (1983). He mentions that the microfauna, as well as a pervasive bioturbation, shell debris (Ostrea sp.) and the presence of glauconite demonstrate a shallow marine origin. The sandstones might represent stacked barrier bar sequences or other shallow marine coastal sand bodies, interbedded with claystones representing either more offshore or lagoonal sedimentation. Other depositional models are, however, also possible.

Fig. 18: The Danish U-1 well. Reference section for the Farsund Formation (legend fig. 33).
U-1

FARSUND FORMATION, REFERENCE SECTION

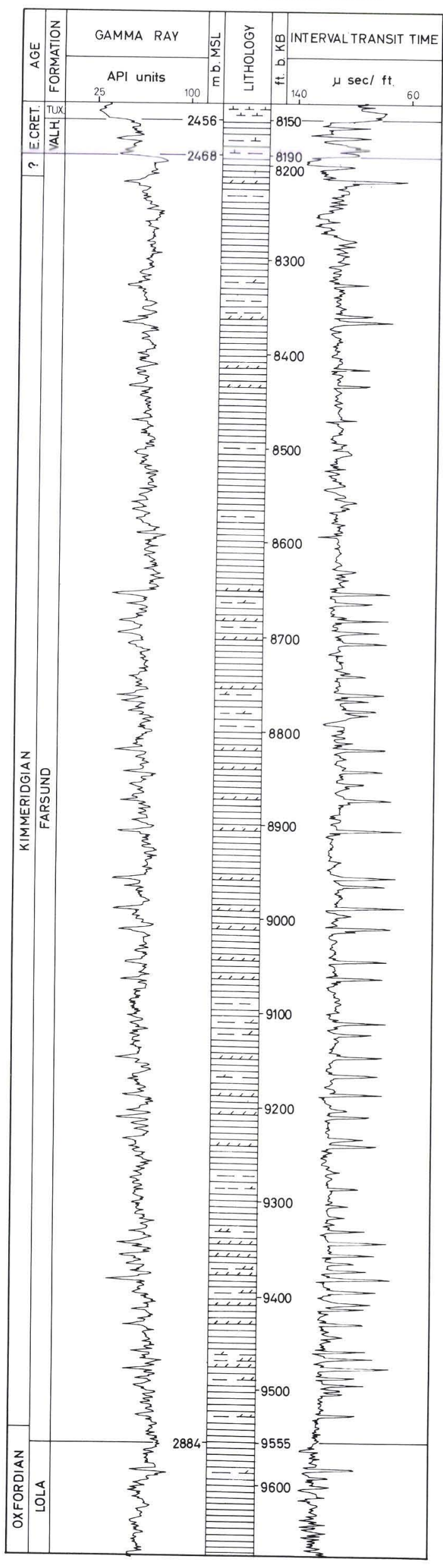

DGU O985 LH+OM. 


\section{Farsund Formation}

Previously this unit was the informal J-4 unit (Koch et al. 1982). It is time-equivalent to the upper part of the Kimmeridge Clay Formation, see fig. 5 (Rhys 1974, NAM \& RGD 1980). The formation has been penetrated in several wells in the Danish Central Trough.
Name:

Named by Vollset \& Doré (1984) after a town in southwestern Norway.

Well type section:

The Norwegian 2/7-3 well from $3414 \mathrm{~m}$ to $3626 \mathrm{~m}$ b. KB (Vollset \& Doré 1984, fig. 40).

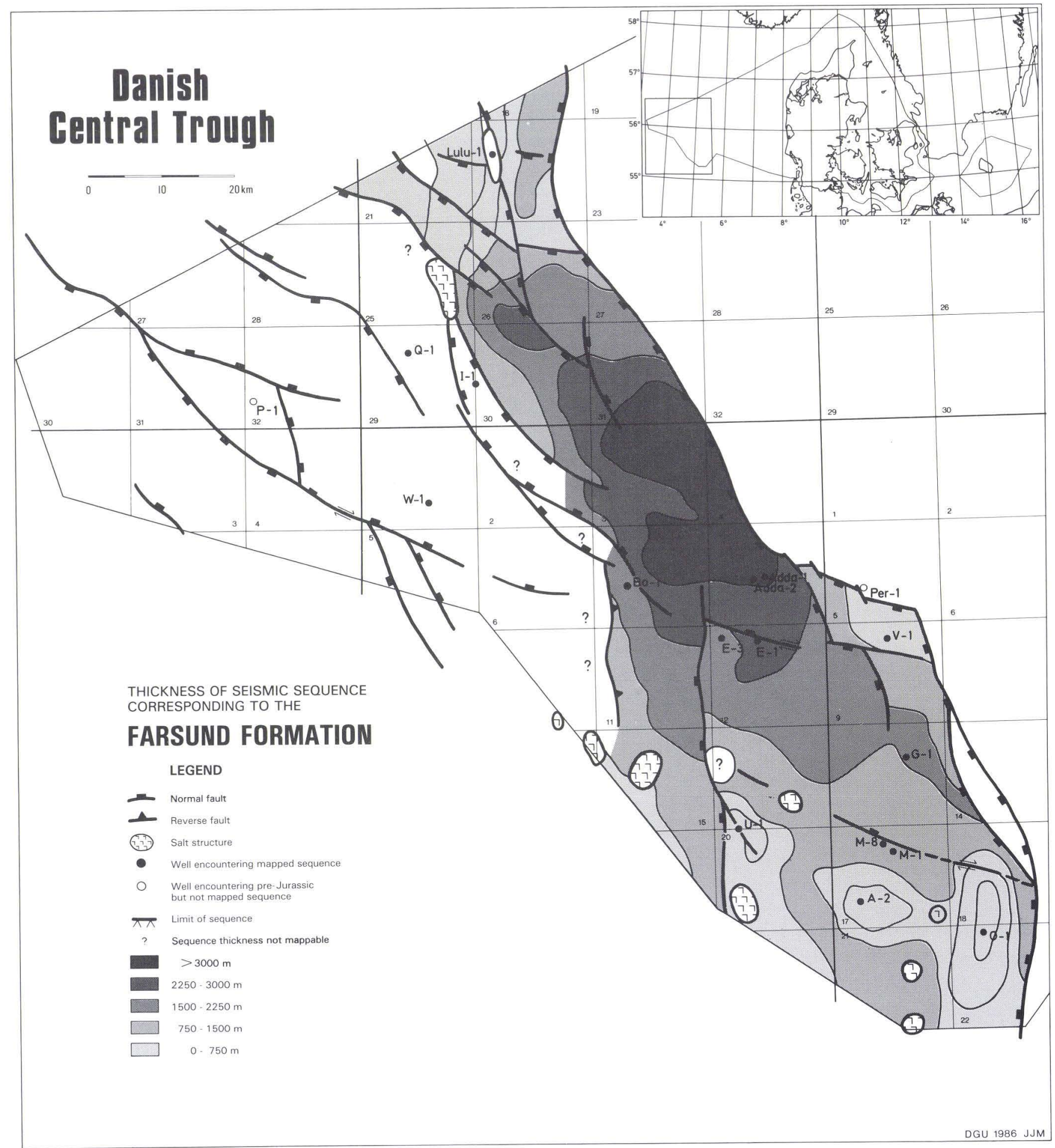

Fig. 19: Thickness and distribution of the seismic sequence corresponding to the Farsund Formation (by Jens Jørgen Mфller). 


\section{Well reference section:}

The Danish U-1 well from $8190 \mathrm{ft}$. to $9555 \mathrm{ft}$. b.KB, 2468-2884 $\mathrm{m}$ b.MSL (fig. 18). The well is located above a salt pillow. This location explains why the uppermost part of the formation, as seen in other wells, e.g. E-1, is missing in the $\mathrm{U}-1$ well.

\section{Thickness:}

Based on seismic data it is assumed that the formation thickness exceeds $3000 \mathrm{~m}$ in the Tail End Graben (fig. 19). In the Salt Dome Province the thickness is 500$1500 \mathrm{~m}$, and on the Heno Plateau some hundred metres. Northwards, in the Feda Graben and the Gertrud Graben, the formation thickness exceeds $1000 \mathrm{~m}$ (see fig. 3).

\section{Lithology:}

The Farsund Formation consists predominantly of medium to dark grey claystones which are carbonaceous and variably calcareous and commonly contain numerous thin beds of brownish dolomite or limestone. Thin sandstone beds occur only locally. The claystones normally contain a few percent organic carbon; the type of organic matter is liptinitic (Lindgreen et al. 1982, Thomsen et al. 1983).

\section{Log characteristics:}

The formation is characterized by relatively high gamma ray values and relatively low sonic velocities, representing a claystone series that is commonly overpressured. High velocity peaks and corresponding low gamma ray readings reflecting dolomite or limestone beds or carbonate cemented sandstone and siltstone beds are a common characteristic for the formation.

\section{Boundaries:}

The Farsund Formation overlies the Lola Formation. The lower boundary with this formation is described under the Lola Formation. The upper boundary, with the Valhall Formation, is well illustrated in the Bo-1 and E-1 wells (see figs. 13 and 14). The boundary is placed at the first significant change from high gamma ray and low sonic velocity readings of the Farsund Formation to low gamma ray and higher velocities in the basal Valhall Formation. Studies of palynofacies carried out on cuttings samples show that this boundary represents a change from an anoxic to an oxic facies (Heilmann-Clausen 1986 and Hoelstad 1986a). How- ever, in some wells, e.g. I-1, the change is found a short distance above the boundary.

\section{Distribution:}

The formation is present throughout the Central Trough but may be thin or absent over intrabasinal highs. Southwards the formation passes into the upper part of the so-called Kimmeridge Clay Formation as defined in the Dutch F3-3 well (NAM \& RGD 1980). Eastwards, the Farsund Formation passes into the Børglum Member in the Danish Subbasin. The Børglum Member has a lower content of organic matter than the Farsund Formation (Erik Thomsen, pers. comm.) and it does not contain dolomite or limestone beds.

Age:

The formation is referred to the Kimmeridgian - Ryazanian on the basis of palynological investigations (Poulsen 1986 and Heilmann-Clausen 1986).

\section{Depositional environment:}

The clays were mainly deposited from suspension in a low energy marine environment. The dominance of liptinitic organic matter indicates open marine conditions. The great differences in thickness (fig. 19) may be explained by redeposition into the deeper parts of the basin. The occurrence of sand intercalations in parts of the Central Trough may represent gravity flows.

\section{Hot unit (new informal unit)}

In the Danish part of the Central Trough, three released wells (figs. 13, 14 and 20) show log motifs very similar to those of the Mandal Formation, which is established in the Norwegian sector (Vollset \& Doré 1984). The Mandal Formation embraces a unit with high gamma ray readings ("hot") and an underlying unit, which has only slightly higher gamma ray readings than the immediately underlying part of the Farsund Formation. Furthermore, this latter unit may have even lower readings than other parts of the Farsund Formation. The lower boundary of a Danish Mandal Formation equivalent would, however, be ambiguous in most of these wells, owing to the very minor differences in the gamma ray and sonic patterns above and below a boundary like this. Furthermore, the hot unit in the Danish Central Trough is not regarded as a single coherent body, but is thought to have developed locally as a response to specific conditions, i.e. the hot unit is 
merely regarded as a sedimentary facies variation of the Farsund Formation.

For these reasons, a formation status could not be given to the hot unit. Instead, an informal member status (within the Farsund Formation) has been proposed, awaiting more information especially from the northern part of the Danish Central Trough. A more precise relationship to the Norwegian Mandal Formation may then be clarified.

\section{Well type section:}

The Danish Bo-1 well from $8434 \mathrm{ft}$. to $8561 \mathrm{ft}$. b.KB, 2537-2576 m b.MSL (fig. 20).

\section{Well reference section:}

The Danish E-1 well from $9771 \mathrm{ft}$. to $9853 \mathrm{ft}$. b.KB, 2940-2966 m b.MSL (fig. 13).

\section{Thickness:}

In the type well, the thickness is $39 \mathrm{~m}$ and in the reference well $25 \mathrm{~m}$.

\section{Lithology:}

The member consists of a dark grey-brown to black claystone which is slightly calcareous to non-calcareous, carbonaceous and in places shaly. The total organic carbon content may be as high as $5-7 \%$ and the type of the organic matter is liptinitic. The unit may contain thin intercalations of dolomite or limestone.

\section{Log characteristics:}

The unit is characterized by a high level of gamma ray radioactivity, caused by a relatively high content of uranium which again is related to the amount of organic material. The level of the gamma ray readings of the unit is significantly higher than that of the under- and overlying Farsund Formation. The sonic velocity is low.

\section{Boundaries:}

In the released wells the unit lies within the Farsund Formation, and the lower and upper boundaries are picked at shifts to significantly lower gamma ray readings in this formation.
$\mathrm{BO}-1$

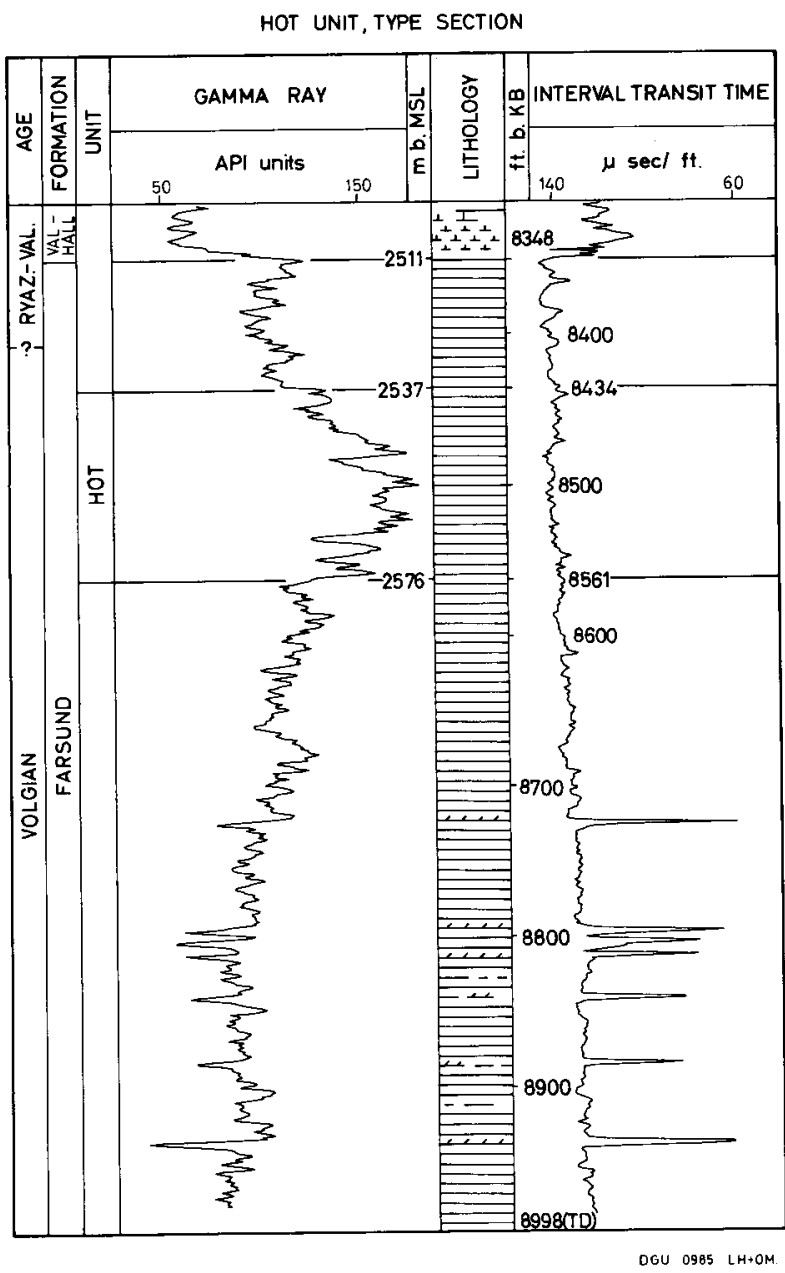

Fig. 20: The Danish Bo-1 well. Type section for the informal hot unit (legend fig. 33).

\section{Distribution:}

At present the unit is known in the southern part of the Tail End Graben, in the Salt Dome Province, and in the Arne-Elin Graben. The extension of the uppermost seismic sequence of the Farsund Formation, embracing the hot unit, is shown in fig. 21. The unit may occur locally in other parts of the Central Trough as well as outside the trough.

Age:

The unit is referred to the Late Volgian - Early Ryazanian on the basis of palynological investigations and ammonite evidence (Birkelund et al. 1983, HeilmannClausen 1986, and Poulsen 1986). 


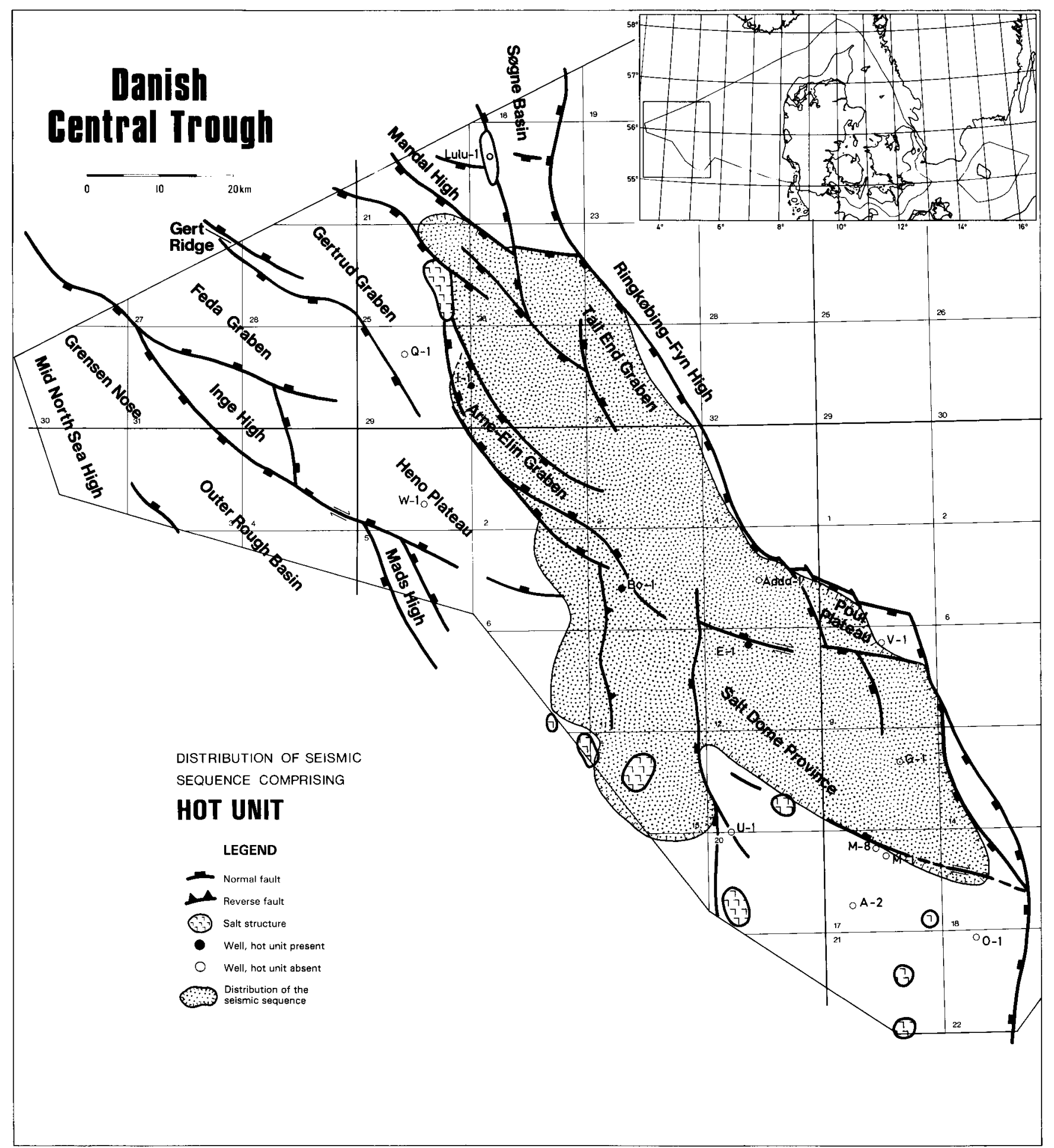

Fig. 21: Extension of the seismic sequence corresponding to the uppermost part of the Farsund Formation which may comprise the hot unit (by Jens Jørgen Møller).

\section{Depositional environment:}

The unit was deposited in an anaerobic marine environment having high organic productivity and preservation potential. The high organic carbon content of the unit, in comparison to the proper Farsund Formation, may be explained by diminished clastic dilution as a result of variations in sedimentation rate.

\section{Poul Formation (new formation)}

The formation has been penetrated in one released well, the V-1, close to the Ringkøbing-Fyn High. Previously the formation was a part of the informal LC-1 unit (Hansen \& Buch 1982). 
Name:

From the Poul structure in the Danish Central Trough (blocks $5505 / 5 \& 7$ ) on which the $\mathrm{V}-1$ well has been drilled (fig. 1).

\section{Well type section:}

The Danish V-1 well from $9356 \mathrm{ft}$. to $9463 \mathrm{ft}$. b.KB, 2818-2851 m b.MSL (fig. 22).

\section{Well reference section:}

None at present.

\section{Thickness:}

$33 \mathrm{~m}$ in the type well.

\section{Lithology:}

The formation consists of dark grey siltstones and light grey, very fine-grained sandstones. The siltstones are partly argillaceous and grade into claystones. The sequence contains glauconite and pyrite. The sandstones may be calcite cemented.

\section{Log characteristics:}

The Poul Formation is characterized by low gamma ray values and intermediate sonic values representing the silt- and sandstone, with few peaks showing higher sonic velocities, that reflect carbonate cemented beds.

\section{Boundaries:}

The formation occurs within and interfingers with the Farsund Formation and the lower and upper boundaries are clearly defined at abrupt changes to lower gamma ray values and higher interval velocities than those of this formation.

\section{Distribution:}

The formation occurs close to the Ringkøbing-Fyn High and it is expected that similar silts and sands may be present locally along the margin of the high and that the formation thickens towards the high. Sand of similar age is present in the Dutch F3-1 well, which is also located near the major boundary fault to the Central
$\mathrm{V}-1$

POUL FORMATION, TYPE SECTION

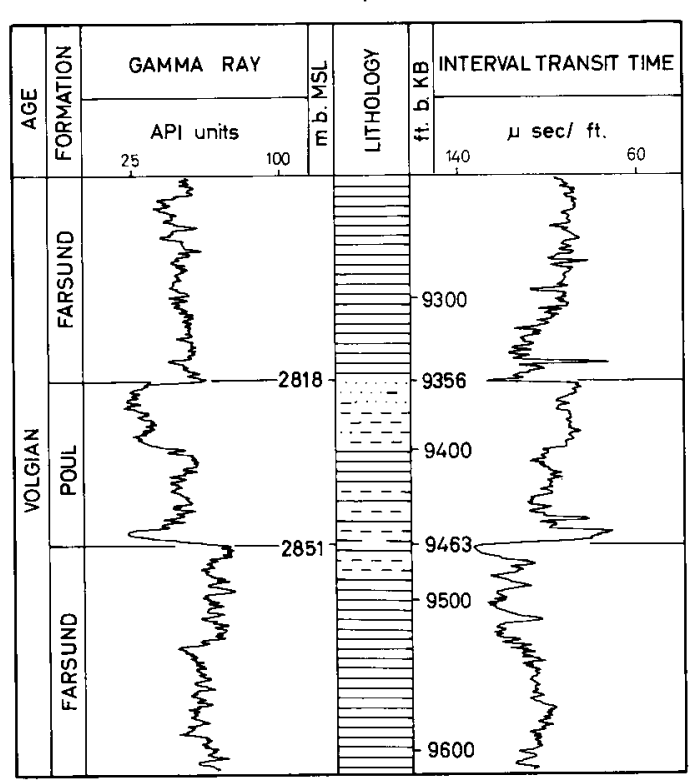

DGU $0985 \mathrm{LH}+\mathrm{OM}$

Fig. 22: The Danish V-1 well. Type section for the Poul Formation (legend fig. 33).

Trough. The Brae sandstone in the south Viking Graben (Stow 1984) may be an equivalent unit as regards age and depositional processes.

Age:

The formation is referred to the Volgian on the basis of palynological and micropalaeontological data (Poulsen 1986, Hoelstad 1986 a).

\section{Depositional environment:}

No core samples are available for facies analysis. A preliminary investigation of the poor data from the V-1 well is presented by Hansen \& Buch (1982). Sediment gravity flows related to the major boundary fault towards the east are suggested as the depositional processes. The maximum subsidence along the fault occurred during the Volgian.

\section{Cromer Knoll Group}

The group was erected by Rhys (1974) to embrace three on- and offshore recognizable marine, arenaceous, argillaceous to marly formations of chiefly Early Cretaceous age. The group was later extended by Deegan \& Scull (1977) to include the sediments between the Kimmeridge Clay (Farsund Formation in Vollset \& Doré 1984) and Chalk Group of the Central North Sea. 
The Cromer Knoll Group is equivalent to the Rijnland Group of the Dutch sector (NAM \& RGD 1980, Crittenden 1982). It may be equivalent to the Vedsted and Rødby Formations of the Danish Subbasin (Larsen 1966 and fig. 4).

Name:

From a bathymetric feature in the southern North Sea.
Type area:

The type area is the southern North Sea (Deegan \& Scull 1977). In the present paper the group is represented in the I-1, Bo-1 and V-1 wells (figs. 26, 27 and $30)$.

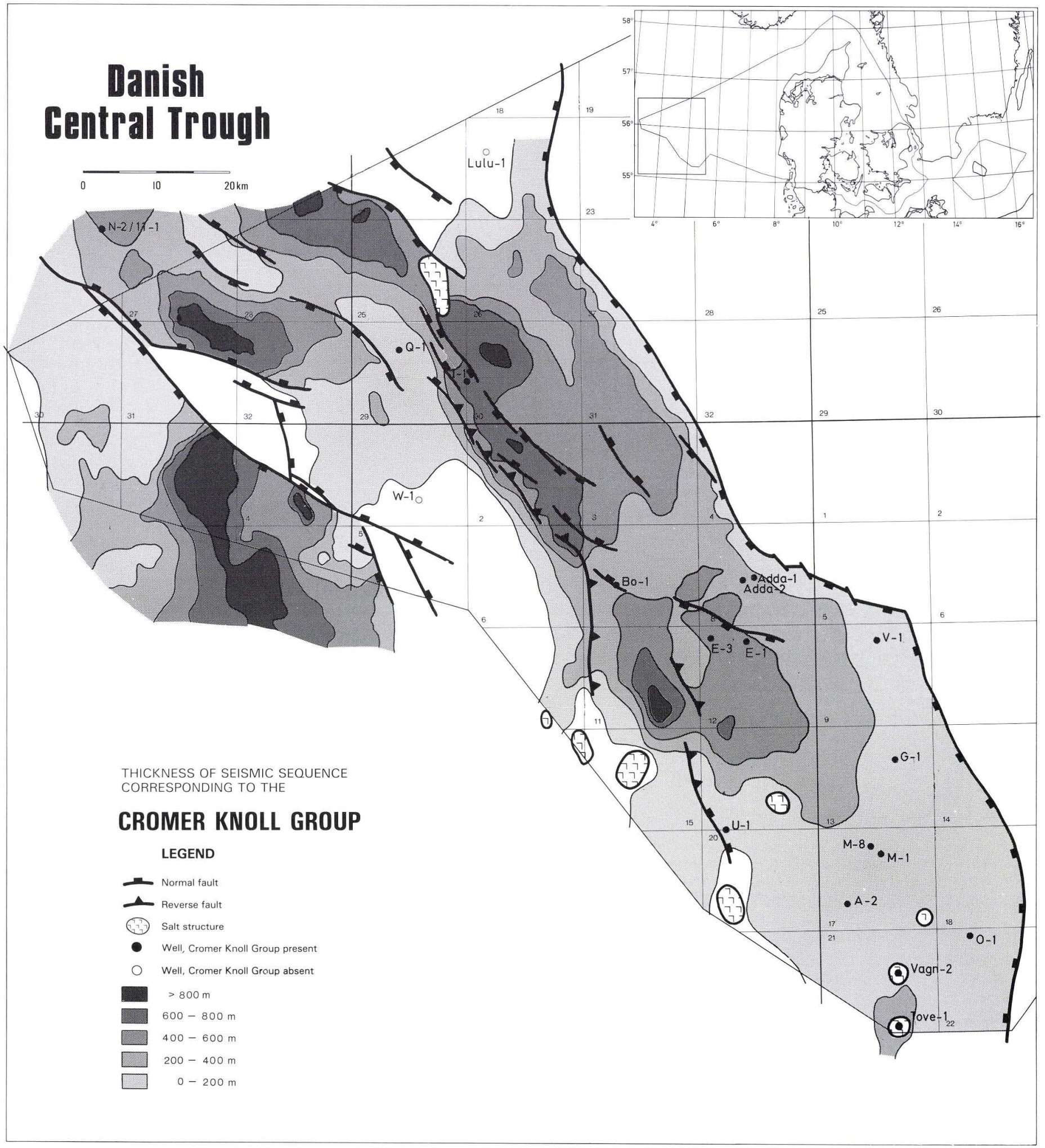

Fig. 23: Thickness and distribution of the seismic sequence corresponding to the Cromer Knoll Group (by Ole Valdemar Vejbak). 


\section{Thickness:}

The thickness varies greatly within small distances. On the basis of seismic data, the greatest thicknesses in the Danish sector are found in the Arne-Elin Graben, the Tail End Graben and the Salt Dome Province, where they may exceed $900 \mathrm{~m}$ (fig. 23). Similar thicknesses are observed in neighbouring areas (Deegan \& Scull 1977, Gowers \& Sæbøe 1985). In the released wells the greatest thickness is encountered in the I-1 well, where the Cromer Knoll Group reaches a thickness of $507 \mathrm{~m}$.

\section{Lithology:}

The group consists of mainly fine-grained, calcareous, argillaceous formations. It may contain arenaceous formations along the margins of the individual subbasins.

\section{Boundaries:}

The lower boundary is generally against sediments of the Farsund Formation and roughly speaking is marked by a sudden or gradual upwards increase in the sonic velocity and decrease in the gamma ray response. The upper boundary is against sediments of the Upper Cretaceous Chalk Group where there is a decrease in gamma ray response and an increase in sonic velocity in the carbonate sediments.

\section{Distribution:}

Widespread in the North Sea region. In the Danish Central Trough the group is only absent on a few highs (fig. 23). The same is the case for the adjoining areas (e.g. Ziegler 1982 and Gowers \& Sæbøe 1985).

Age:

Ryazanian (usually Late) - Albian according to palynostratigraphic investigations (Heilmann-Clausen 1986).

\section{Subdivision:}

Five formations are recognized within the Danish sector: the Valhall, Vyl, Tuxen, Sola and Rødby Formations.

\section{Valhall Formation (emended)}

The formation was erected by Deegan \& Scull (1977)
2/11-1

(NORWEGIAN WELL)

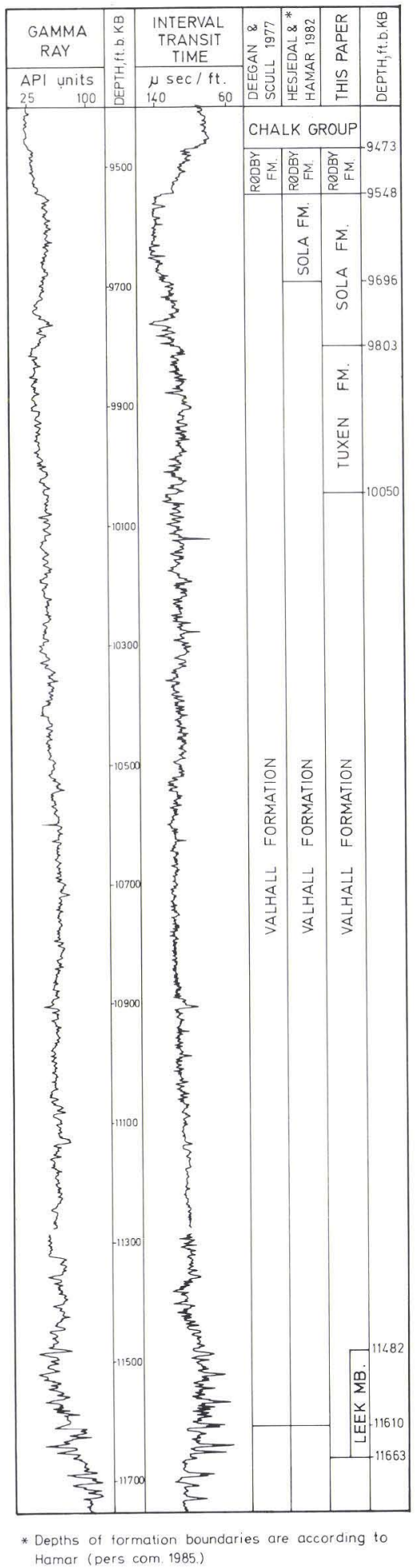

Fig. 24: The Cromer Knoll Group in the Norwegian 2/11-1 well.

and later extended into the Danish sector by Hansen \& Buch (1982). In the Norwegian area Hesjedal \& Hamar (1983) recognized a unit at the top of the Valhall Formation which they gave formation status (Sola Formation). The same formation is recognized in the Danish Central Trough. Additionally, a chalk-marl sequence 
below the Sola Formation is distinguishable from the Valhall Formation and erected as an independent formation, the Tuxen Formation (see figs. 4 \& 24). Consequently, the Valhall Formation is redefined as follows.
Well type section:

The Norwegian 2/11-1 well from $10050 \mathrm{ft}$. to $11663 \mathrm{ft}$. b.KB, 3036-3528 m b.MSL (fig. 24).
Name:

From the Valhall Field in Norwegian block 2/8.
Well reference sections:

The wide variation of $\log$ pattern, thickness and litho-

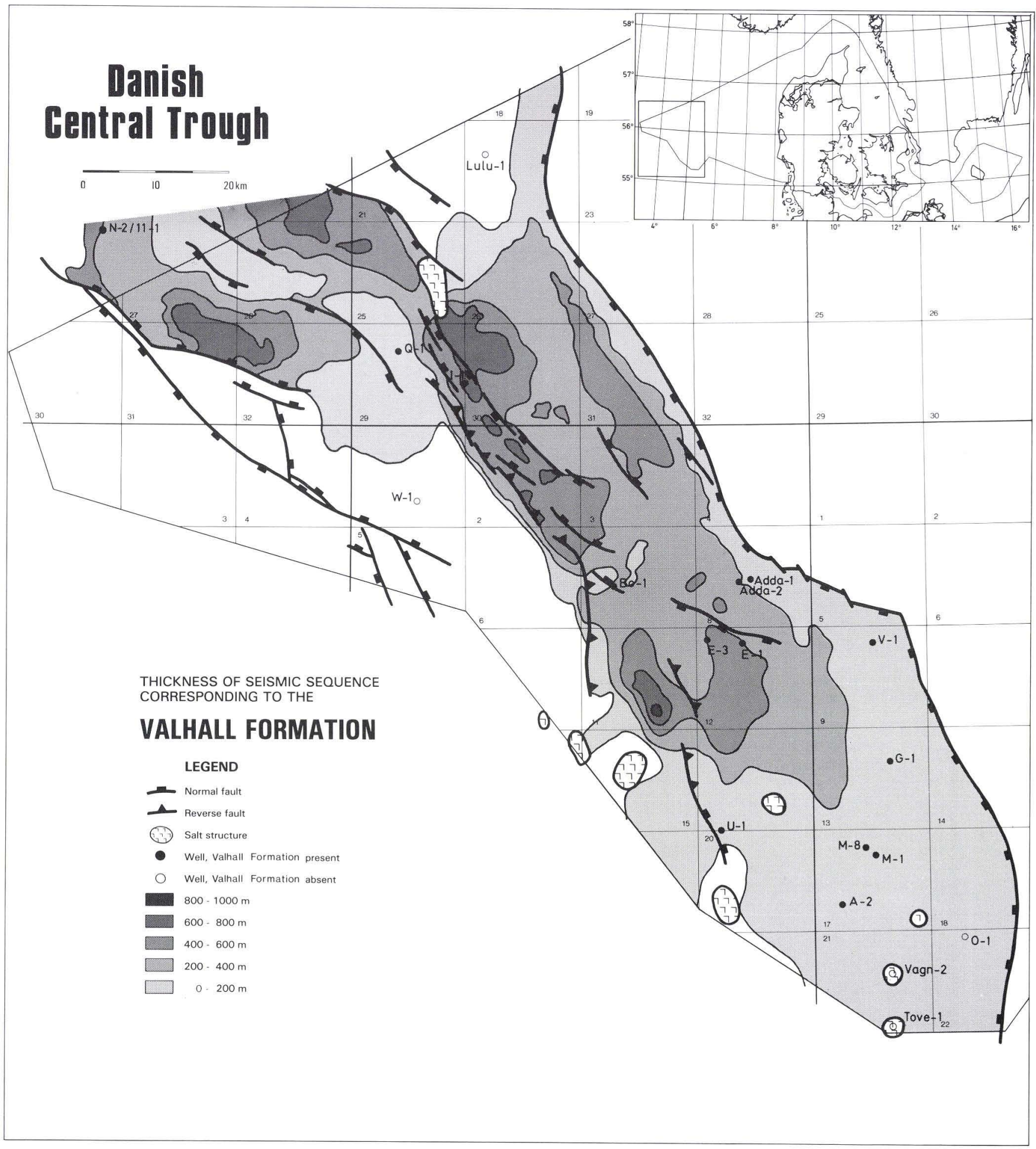

Fig. 25: Thickness and distribution of the seismic sequence corresponding to the Valhall Formation (by Ole Valdemar Vejbak). 
logy is illustrated in the following Danish wells (figs. 26, 27 and 29).

I-1: $\quad 9798 \mathrm{ft} .-11018 \mathrm{ft}$. b.KB, 2949-3321 m b.MSL.

Bo-1: $\quad 7896 \mathrm{ft} .-8348 \mathrm{ft}$. b.KB, 2373-2511 m b.MSL.

Adda-1: $7700 \mathrm{ft} .-8478 \mathrm{ft}$ b. KB, 2313-2550 m b.MSL.

E-1: $\quad 8296 \mathrm{ft}$ - $-9726 \mathrm{ft}$. b.KB, 2491-2927 m b.MSL.

\section{Thickness:}

Maximum thickness of the formation is found in the Arne-Elin Graben and in the northern part of the Salt Dome Province where it is up to $900 \mathrm{~m}$ (fig. 25). In the released wells the greatest thickness is observed in the E-1 well (436 m). As reflected by the seismic mapping, the formation had several depocentres, and the thickness varies greatly within small distances (Vejbæk 1986).

\section{Lithology:}

The lower part of the Valhall Formation (Leek Member) comprises a sequence of interbedded claystone, marlstone and limestone. A more detailed description of this member is given below.

Where the Valhall sequence above the Leek Member is thick, it is dominated by claystone, frequently laminated, containing subordinate layers of marlstone and calcilutitic limestone (fig. 26). The claystone may be silty, and rare siltstone or fine-grained sandstone layers and laminae are present. The claystone is generally light grey to medium grey, but dark grey, olive grey, greenish and brownish colours occur. The claystone varies from slightly to highly calcareous, and mica, pyrite and glauconite are common.

In areas where the Valhall Formation above the Leek Member is thin, the lithology comprises interbedded marlstone and claystone interspersed with subordinate limestone layers. Generally speaking, marlstone becomes the dominant lithology upwards, as seen in the Bo-1 well (fig. 27).

The marlstone ranges in colour between light grey, light greenish grey and light olive grey and contains the same accessory minerals as the claystone. Both the marlstone and claystone may contain biogenic structures. The organic content is dominated by phyrogen, spores and pollen, cuticula and dinoflagellates (Hoelstad 1986a) and the total organic carbon content averages $0.3-0.6 \%$ (Thomsen et al. 1983)

\section{Log characteristics:}

In areas where the formation is developed in a claystone facies it is characterized by very constant gamma ray readings and fairly constant sonic velocity (wells
2/11-1 and E-1, fig. 29) whereas the gamma and sonic logs exhibit a more "nervous" pattern where the formation is developed in a more marly facies (wells Bo-1 and I-1, fig. 29).

The lower part of the formation (Leek Member) is developed as a unit yielding rather low gamma ray readings and high sonic velocity on which peaks of gamma ray lows and corresponding high sonic velocity are superimposed.

\section{Subdivision:}

In the Danish Central Trough and in adjoining areas, a basal member of the Valhall Formation is erected and named Leek Member (defined below).

A marker bed, informally named marker-A, is found locally in the monotonous sequence above the Leek Member (fig. 29). The bed is c. $3 \mathrm{~m}$ thick and corresponds to a double or single peak showing low gamma ray values and high sonic velocity. The position of this marker bed, probably consisting of marlstone, seems to be congruent with the top of one of the seismic units of Vejbæk (1986).

\section{Boundaries:}

The boundary between the organic rich sediments of the Farsund Formation (or Mandal Formation/hot unit) and the sediments of the Valhall Formation is easy to recognize in most wells. It is normally characterized by a pronounced drop upwards in gamma ray response and a corresponding increase in sonic velocity correlatable with a change in lithology (e.g. Bo-1, I-1, E-1, fig. 29). Furthermore, the boundary is marked by a very pronounced change in the content and type of organic matter (Thomsen et al. 1983, Hoelstad 1986a). The lower boundary is described in detail above under the Farsund Formation.

The upper boundary with the Tuxen Formation is placed where the sonic velocity increases and the gamma ray readings decrease, reflecting the change in lithology to marlstone and chalk. This boundary is gradual in the Feda Graben and in the Tail End Graben, whereas the boundary in the Salt Dome Province is very distinct.

\section{Distribution:}

The distribution of the Valhall Formation in the Danish Central Trough is indicated in fig. 25. The formation is also present in the Outer Rough Basin (B-1 well, German sector). In the British and Norwegian sectors this formation is just as widespread and it is only absent on a few highs (Deegan \& Scull 1977, Hesjedal \& Hamar 1983). 


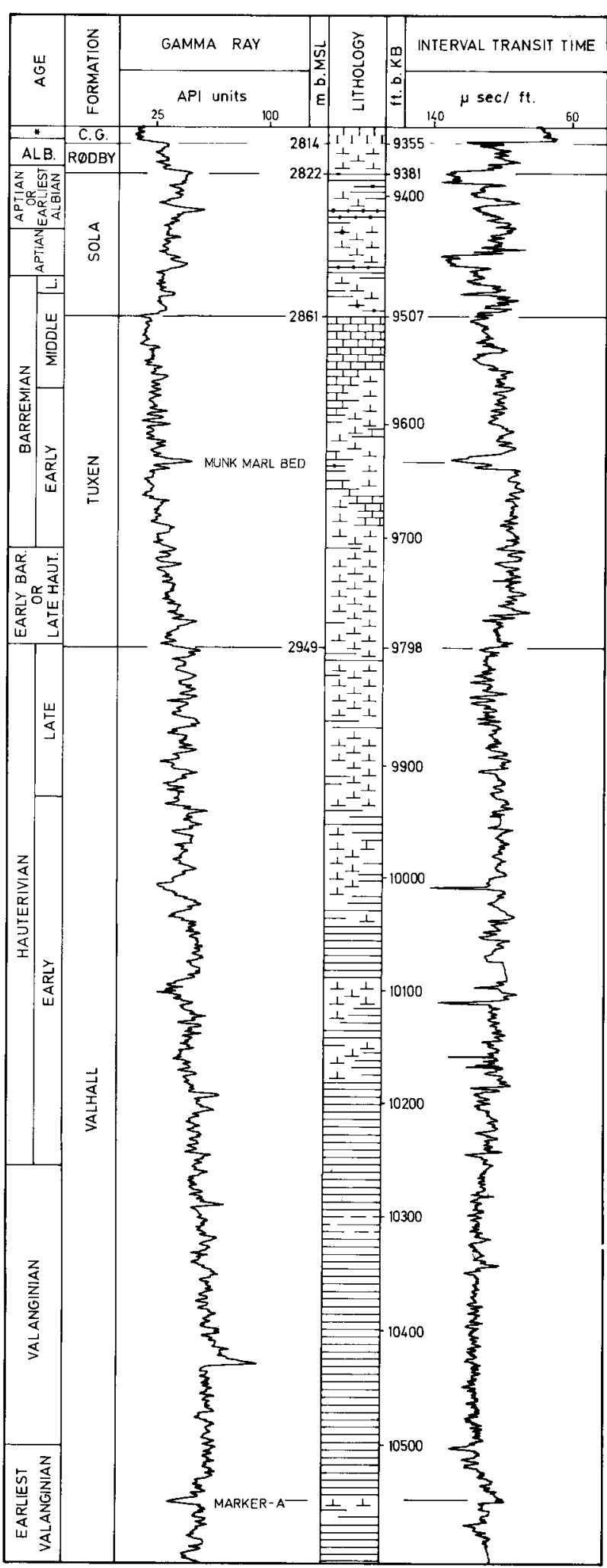

* Late Cretaceous

C.G.: Chalk Group

The extension towards the south, west and east is more speculative, but the formation is partly timeequivalent to the Vlieland Shale (NAM \& RGD 1980) and the Speeton Clay (Rhys 1974) to the south and
$1-1$

(CONTINUED)

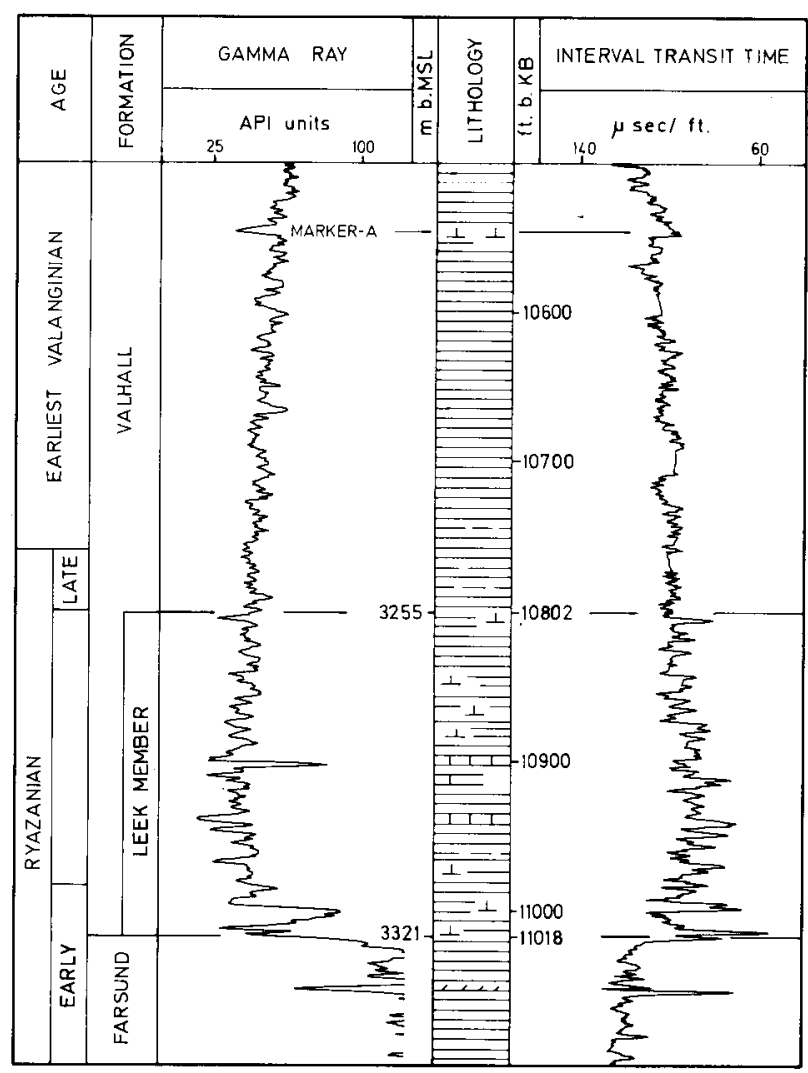

DGU 0885 TF.

Fig. 26: The Danish I-1 well. Type section for the Sola and Tuxen Formations and the Leek Member, and reference section for the Valhall Formation and the Munk Marl Bed (legend fig. 33).

west respectively, and to the Vedsted Formation (Larsen 1966) to the east in the Danish Subbasin (fig. 4).

Age:

On the basis of palynological investigations, the Valhall Formation is usually referred to the Late Ryazanian to earliest Late Hauterivian and no major hiati are encountered in the sequence (Heilmann-Clausen 1986).

\section{Depositional environment:}

The palynofacies characteristics (Hoelstad 1986a) and dinoflagellate and foraminiferal evidence indicate deposition in an open marine environment having well oxygenated bottom water. The large content of terrigenous organic matter, reworking of dinoflagellates (Heilmann-Clausen 1986), the dipmeter pattern and the variations of lithology are interpreted as the result of gravity flow deposition alternating with deposition of pelagic and hemipelagic clay and pelagic carbonate mud. 


\section{Leek Member (new member)}

This member is equivalent to the informal Valhall-1 unit of Hansen \& Buch (1982).

\section{Name:}

Inspired by the shape of the figure created by the gamma ray and sonic logs of the Valhall Formation: the logs sketch the shape of a leek. The Leek Member corresponds to the thick lower part of this "leek".

$\mathrm{BO}-1$

REFERENCE SECTION: RODBY, SOLA,TUXEN, VALHALL FORMATIONS, LEEK MEMBER.

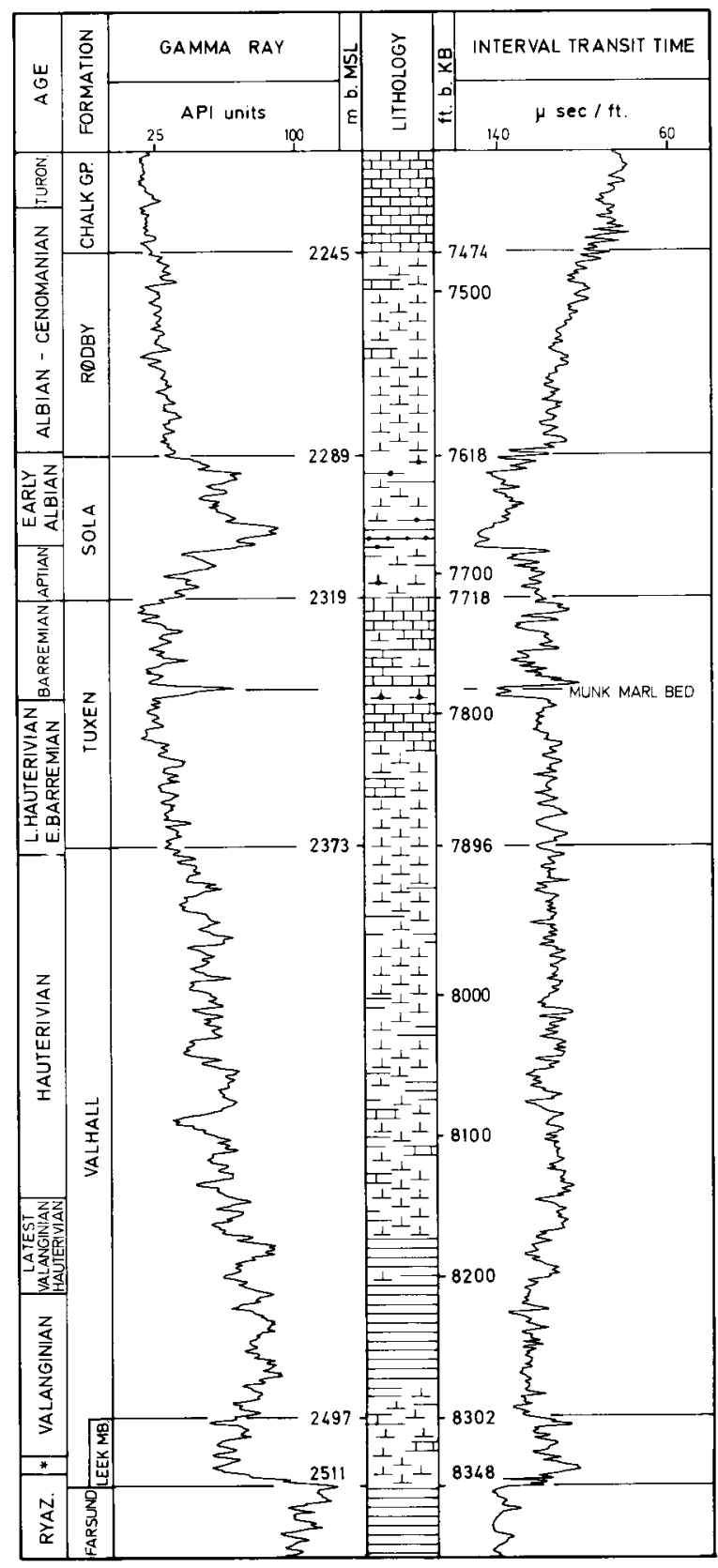

* Late Ryazanian-Early valanginian

OGU 0985 iFs

Fig. 27: The Danish Bo-1 well. Reference section for the Rødby, Sola, Tuxen, and Valhall Formations and the Leek Member (legend fig. 33).
Well type section:

The Danish I-1 well from $10802 \mathrm{ft}$. to $11018 \mathrm{ft}$. b.KB, 3255-3321 m b.MSL (fig. 26).

Well reference sections:

The Danish Bo-1 well from $8302 \mathrm{ft}$. to $8348 \mathrm{ft}$. b. KB, 2497-2511 m b.MSL (fig. 27).

The Norwegian 2/11-1 well from $11482 \mathrm{ft}$. to $11663 \mathrm{ft}$. b.KB, 3473-3528 m b.MSL (fig. 29).

\section{Thickness:}

The thickness of this member is generally too small for the unit to be properly mapped seismically. Wells encountering the unit are indicated on a map showing the extension of the lowermost seismic unit mapped by Vejbæk (1986), fig. 28. The greatest thickness (66 m) is drilled in the I-1 well and the smallest $(12 \mathrm{~m})$ in Q-1. Due to poor seismic resolution both wells are situated outside the mappable area.

\section{Lithology:}

In most wells the lithology is light grey to medium grey and olive grey, very calcareous claystone, with common pyrite and lignite. The claystone is interbedded with several, up to $1 \mathrm{~m}$ thick beds of light olive grey marlstone or yellowish grey to white, calcilutitic limestone (fig. 26).

In a few wells the member is developed as a marlstone with limestone intercalations (e.g. Bo-1, fig. 27). Thin silt- or fine-grained sandstone layers may be present within the unit.

\section{Log characteristics:}

The member is characterized by rather low gamma ray readings and high sonic velocity compared with the units below and above. The gamma ray response gradually decreases upwards from the lower boundary and reaches a low in the middle of the sequence whence it increases. The opposite happens with the sonic velocity. High sonic velocity peaks and corresponding gamma ray lows reflecting the position of hard marl- or limestone layers are superimposed on this pattern.

In a few wells (Bo-1, Q-1, fig. 27) the upper and lower boundaries of the member are very abrupt and the gamma ray and sonic logs can be described as box shaped. 


\section{Boundaries:}

The lower boundary is identical to the lower boundary of the Valhall Formation. The upper boundary is placed where the last high sonic velocity peak and gamma ray low occur. This boundary is approximately congruent with the point where constant gamma ray response and velocity, characteristic for the rest of the Valhall Formation, are reached.

\section{Distribution:}

Wells encountering this member are indicated on fig. 28 . The member is definitely present to the north in the Norwegian Central Trough (e.g. the 2/11-1 well). To the south it seems to be absent. In these areas timeequivalent units, the Vlieland Sandstone Member and the Spilsby Sandstone (NAM \& RGD 1980, Rhys 1974), are developed. In the Norwegian part of the

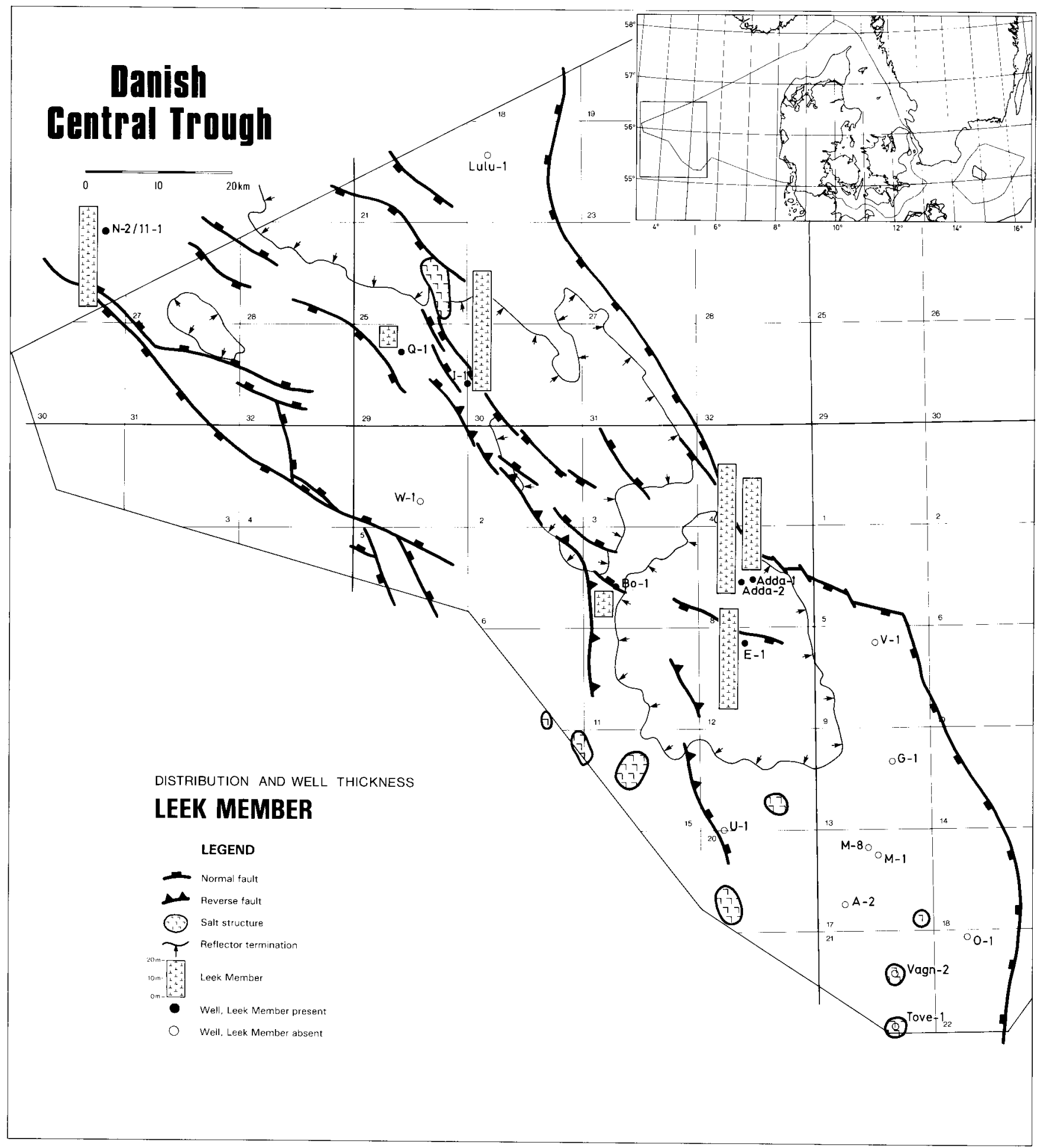

Fig. 28: Extension of the seismic sequence corresponding to the lower part of the Vallhall Formation including the Leek Member (modified from Vejbak 1986). Distribution and thickness of the Leek Member as encountered in wells. 
CROMER KNOLL GROUP IN

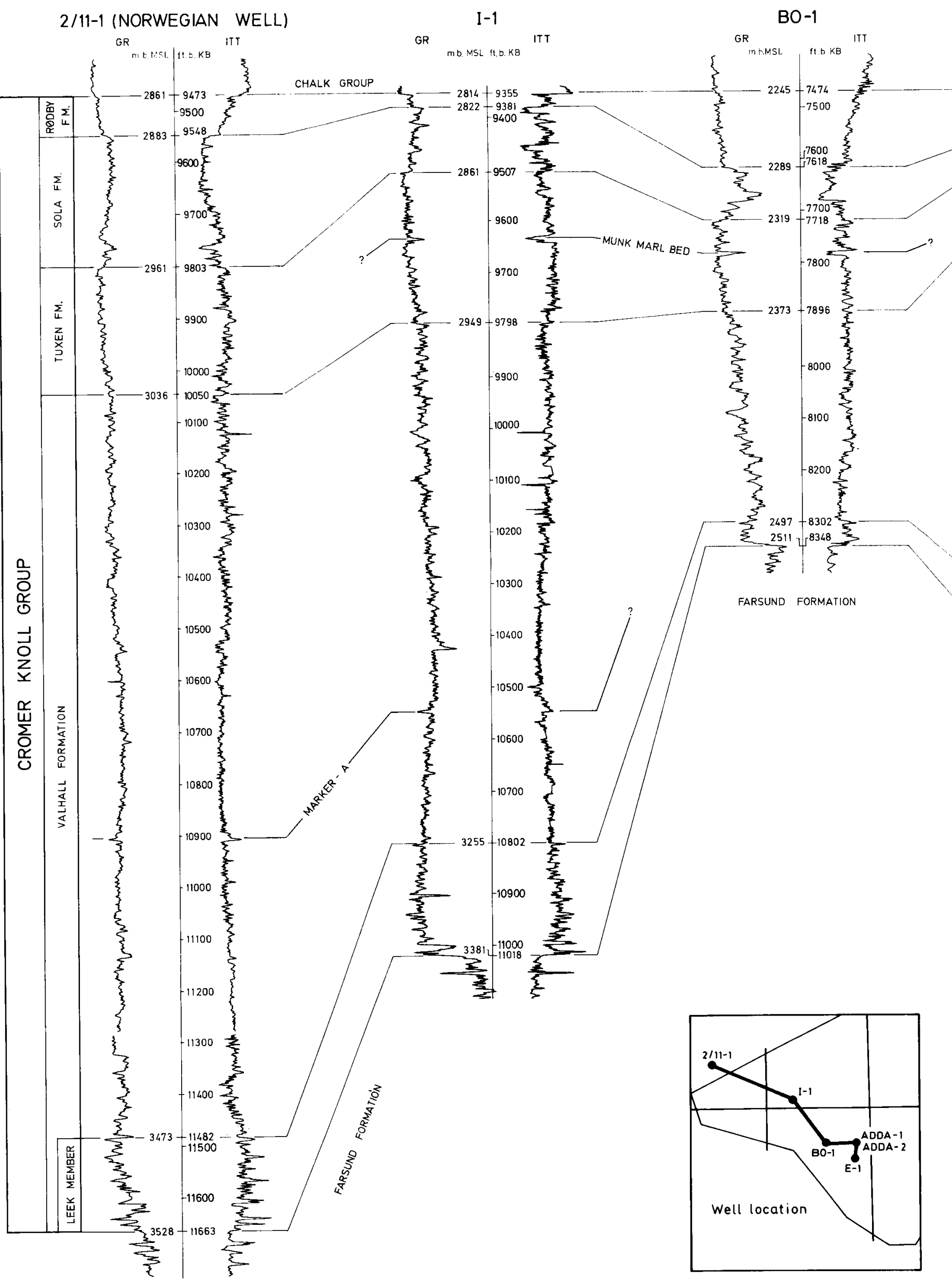




\section{THE DANISH CENTRAL TROUGH}

ADDA-2

ADDA-1

$$
E-1
$$
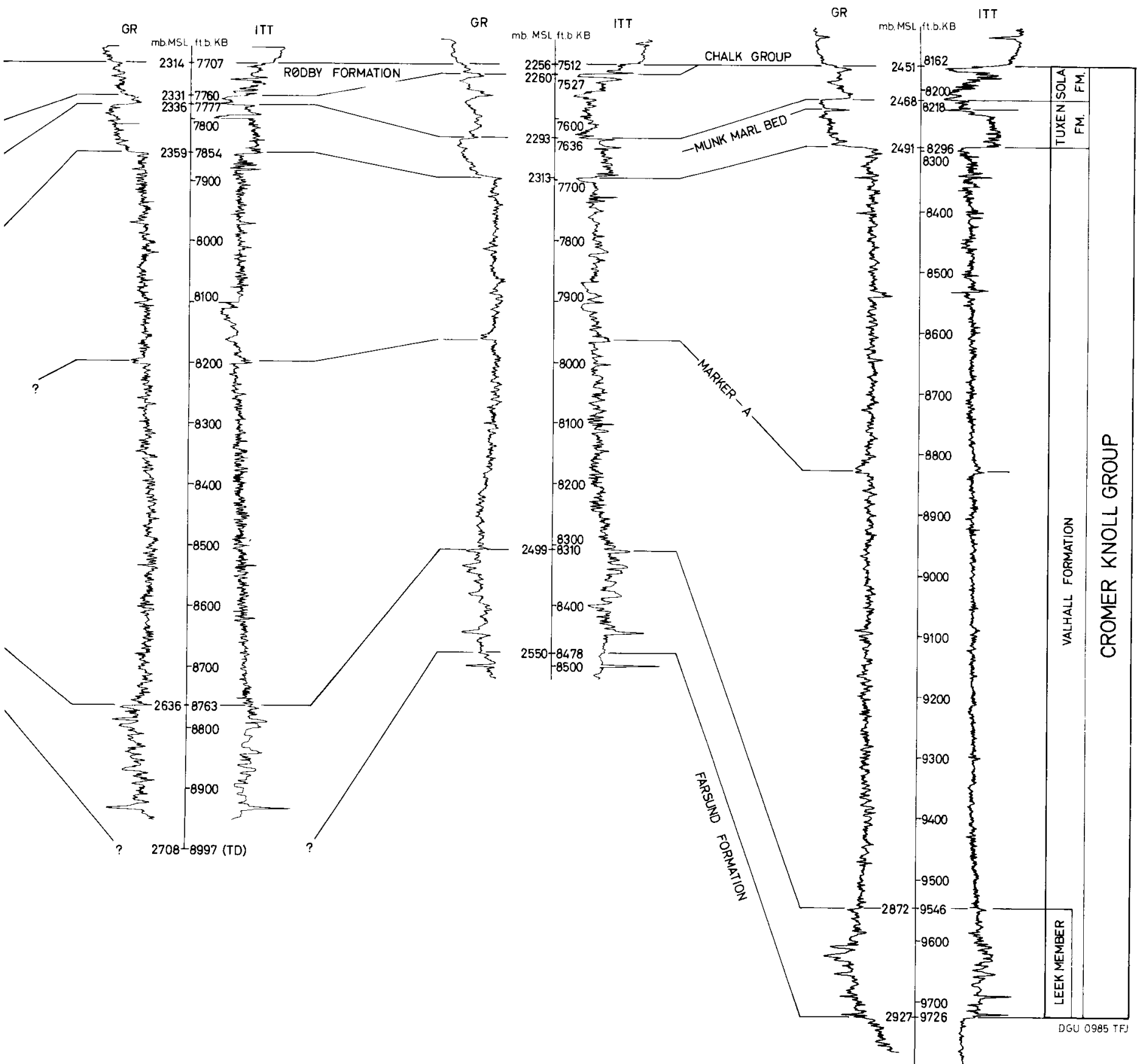

Fig. 29: The Cromer Knoll Group in the Danish I-1, Bo-1. Adda-2. Adda-1 and E-1 wells and in the Norwegian 2/11-I well.

Norwegian-Danish Basin the member also seems to be absent, see fig. 4 (cf. Olsen \& Strass 1982).

\section{Age:}

The member is dated as being of Ryazanian to earliest Valanginian age on the basis of palynological data (cf. Heilmann-Clausen 1986).

\section{Depositional environment:}

The Leek Member is time-equivalent to the lower part of the Utvik Formation in the Norwegian sector (fig. 4). This formation is a condensed sequence of marine carbonates deposited on submarine highs which were isolated and therefore only received little clastic material (Hesjedal \& Hamar 1983).

A similar explanation does not apply to the Leek 
Member. The Leek Member is clearly present in the basinal areas, both in the Norwegian and Danish Central Trough, and not solely found at structural highs. It is uncertain why the Late Ryazanian transgression only temporarily caused a decreased clastic sedimentation in the basinal areas, but it is tentatively suggested, that clastic sediments initially were captured in, and filled up, newly deepened, land-near waters. As a result, pelagic carbonate briefly became an important rock building component in basinal areas.

\section{Vyl Formation (new formation)}

The informal LC-1 unit, described by Hansen \& Buch (1982), includes the Volgian Poul Formation and the Early Cretaceous Vyl Formation. Time-equivalent sandstone units - the Devil's Hole Formation, the Spilsby Sandstone and the Vlieland Sandstone Member - are present in the British and Dutch sectors (fig. 4).

Name:

After the name of a lightship positioned c. $40 \mathrm{~km}$ WSW of the westernmost point of Jylland (Blåvandshuk).

\section{Well type section:}

The Danish V-1 well from $8974 \mathrm{ft}$. to $9116 \mathrm{ft}$. b.KB, 2702-2745 m b.MSL, see fig. 30 .

\section{Well reference section:}

None at present.

\section{Thickness:}

$43 \mathrm{~m}$ in the type well.

\section{Lithology:}

Mainly olive grey to greenish grey siltstone, non- to slightly calcareous, locally very calcareous and generally glauconitic and pyritic. Interbedded with subordinate layers of fine-grained sandstone, silty claystone and marlstone. Palynofacies analysis clearly differentiates this formation from those above and below by a pronounced relative increase in land derived organic matter (Hoelstad 1986a).

\section{Log characteristics:}

The gamma ray response of this unit is comparatively low with only minor oscillations. The sonic velocity is characterized by abundant high peaks probably reflecting carbonate cemented beds.

\section{Boundaries:}

The boundaries of this formation are easily distinguished on both the gamma ray and sonic velocity logs. The boundary with the underlying Farsund Formation is marked by a pronounced decrease upwards in gamma ray response and an increase in sonic velocity. Vice versa at the boundary with the overlying Valhall Formation (fig. 30).

\section{Distribution:}

The formation occurs close to the western margin of the Ringkøbing-Fyn High (fig. 23). Similar clastic bodies may be present elsewhere along the margin of the high.

Age:

Dated palynologically as being of Late Ryazanian to Early Valanginian age (Heilmann-Clausen 1986). 


\section{Depositional environment:}

In the type well the sequence is tentatively interpreted as a sequence through a distal part of a gravity flow deposit genetically connected to active fault scarps and emergent highs to the east (Hansen \& Buch 1982). This model could further explain the frequently reported presence of sand and silt layers within the time-equivalent Leek Member. Nevertheless, other depositional models could just as well apply and must be taken into consideration.

\section{Tuxen Formation (new formation)}

This new formation is part of the informal Valhall-3 unit of Hansen \& Buch (1982). It has two equivalents in the Norwegian sector: A part of the Utvik Formation as described by Hesjedal \& Hamar (1983) and the upper, carbonate rich part of the Valhall Formation in basinal areas, see fig. 4 (Deegan \& Scull 1977, Hesjedal \& Hamar 1983).

\section{Name:}

From a bathymetric feature c. $21 \mathrm{~km}$ due west of Blåvandshuk, the westernmost point of Jylland.

\section{Well type section:}

The Danish I-1 well from $9507 \mathrm{ft}$. to $9798 \mathrm{ft}$. b.KB, 2861-2949 m b.MSL (fig. 26).

\section{Well reference sections:}

Bo-1 (Denmark): 7718 ft. - 7896 ft. b.KB, 2319-2373 m b.MSL.

E-1 (Denmark): 8218 ft. - 8296 ft. b.KB, 2468-2491 m b.MSL.

2/11-1 (Norway): 9803 ft. - 10050 ft. b.KB, 2961-3036 m b.MSL.

See also figs. 24,27 and 29.

\section{Thickness:}

This formation could not be mapped seismically. A map showing the extension of the uppermost Lower Cretaceous seismic unit including the Tuxen Formation is given on fig. 32. The formation is $24 \mathrm{~m}$ thick in the reference well E-1. This appears to be a normal thickness in the Salt Dome Province away from salt struc- tures. The thickness increases towards the northwest and reaches $89 \mathrm{~m}$ in the $\mathrm{I}-1$ well and $75 \mathrm{~m}$ in the Norwegian 2/11-1 well in the Feda Graben.

\section{Lithology:}

Marlstone is the dominating lithology in the lower part of the formation where marlstone and chalk are found interbedded with bed thicknesses varying from $5-10 \mathrm{~cm}$ up to around $1 \mathrm{~m}$. The formation is generally terminated by a thick chalk sequence with subordinate marlstone layers (figs. 26 and 27). Marlstone and chalk layers with the features characteristic of debris flow deposits are present. Some intervals are well bioturbated. The bioturbation creates diffuse layer boundaries. The only identifiable trace fossils are abundant Chondrites and extremely rare Zoophycos.

The chalk varies in colour from white to very pale orange or yellowish grey, but greenish and reddish colours occur. The marlstone is generally light grey to greenish grey or olive grey but red-brown colours may be found in some wells. The chalk is petrographically a micrite (sensu Folk 1962) with allochems dominated by planktonic foraminifera. The micritic matrix consists of calcareous nannofossils. Identified macrofossils include among others ammonites, belemnites and inoceramid pelecypods.

A marlstone bed, - the Munk Marl Bed - is frequently encountered within the formation. This key bed is described below as a separate lithostratigraphic unit.

\section{Log characteristics:}

The gamma ray log is characterized by rather low readings reflecting the calcareous lithology. The gamma ray response decreases upwards through the sequence of interbedded marlstone and chalk, simultaneously with gamma ray fluctuations reflecting these lithology variations. It reaches low, though still fluctuating values in the uppermost chalk sequence. The sonic velocity to some degree mirrors the picture of the gamma ray readings. The sonic velocity is high and fluctuating in the lower part but decreases in the more porous and less hardened chalk sequence (fig. 29).

\section{Subdivision:}

The Munk Marl Bed is present in this formation and corresponds to a pronounced high gamma ray peak and sonic velocity low. This bed is described below. 


\section{Boundaries:}

The lower boundary of the Tuxen Formation is described under the Valhall Formation.

The upper boundary is easy to pick and is placed where the gamma ray response starts to increase reflecting the first beds of the carbonaceous marlstones of the Sola Formation. The boundary is normally reflected on the sonic $\log$ as a decrease in velocity.

\section{Distribution:}

This formation is one of the most widespread Lower Cretaceous formations. The base is equivalent to the base of the uppermost Lower Cretaceous seismic unit of Vejbæk (1986), see fig. 31. This is the most widespread unit and onlaps former emergent highs. In the Salt Dome Province the formation is absent in some areas, probably owing to later erosion.

The Tuxen Formation may be recognized in both the German, Norwegian and British sectors of the central North Sea and probably even further north (e.g. the UK 29/25-1 well, the Norwegian 2/11-1 well, cf. Deegan \& Scull 1977; the German B-1 well, cf. Rasmussen 1974).

In the northwestern part of the Norwegian-Danish Basin a calcareous unit is present at a similar stratigraphic position (Olsen \& Strass 1982) and may well be identical to the Tuxen Formation, but in the Danish Subbasin it seems to be absent. The Tuxen Formation is time-equivalent to the upper part of the Vlieland Shale Member to the south and southwest in the Dutch and British North Sea sectors (fig. 4).

\section{Age:}

On the basis of palynological, nannofossil and ammonite evidence, the formation is dated as being of Late Hauterivian to Middle (or Late) Barremian age (Heilmann-Clausen 1986, Thomsen 1986). Both boundaries of the formation are possibly isochronous.

\section{Depositional environment:}

The Tuxen Formation was deposited during a period of decreasing tectonic activity (Vejbæk 1986). Deposition was dominated by pelagic marl and chalk oozes which blanketed large areas of the North Sea.

The bottom waters were mainly well oxygenated except for a short period during deposition of the Munk Marl Bed and other minor periods characterized by stagnant bottom waters. The latter situation is characterized in the rock record by the exclusive presence of the trace fossil Chondrites, which has been indicated to be diagnostic of beginning anoxia (Bromley \& Ekdale 1984).

The lower boundary of the Tuxen Formation seems to be an unconformity that can be traced seismically as a truncation of the reflectors below (Vejbæk 1986). It is possible that thickness variations to some degree should be explained by an earlier onset of deposition in the Feda and Tail End Grabens, where the lower sequence of interbedded marlstone and chalk is thicker and the boundary against the Valhall Formation is gradual (figs. $29 \& 31$ ).

\section{Munk Marl Bed (new key bed)}

Name:

From a bathymetric feature c. $17 \mathrm{~km} \mathrm{WSW}$ of the westernmost point of Jylland (Blåvandshuk).

\section{Well type section:}

The Danish E-1 well from $8232 \mathrm{ft}$. to $8233 \mathrm{ft}$. b.KB, 2471.9-2472.2 m b.MSL (core depth), see fig. 29.

\section{Well reference section:}

The Danish I-1 well from $9635 \mathrm{ft}$. to $9639 \mathrm{ft}$. b.KB, 2899.6-2900.8 m b.MSL (fig. 26).

\section{Thickness:}

The thicknesses (0.3-1 m) encountered in the type and reference sections appear to be representative for the study area.

\section{Lithology:}

Black, laminated, pyritic, shaly marlstone containing subordinate non-calcareous claystone laminae. The content of organic carbon is very high (max. measured $14 \%$ ) and consists predominantly of amorphous organic matter (Hoelstad, pers. comm. 1985).

\section{Log characteristics:}

On gamma and sonic logs, the bed is easily recognized as a pronounced high gamma ray peak and sonic velocity low within the uppermost chalky part of the Tuxen Formation. 


\section{Distribution:}

Recognized over large areas of the central North Sea both in the German, Danish, Norwegian and British sectors.

Age:

Barremian (Early ?), (Thomsen 1986).

\section{Depositional environment:}

Deposited during a period of oxygen deficient bottom waters possibly accompanied by a decrease in production of calcareous plankton.

\section{Sola Formation (emended)}

The formation was named and described, but not formally defined in a type section etc. by Hesjedal \& Hamar (1983) to embrace the upper part of the Valhall Formation of Deegan \& Scull (1977, fig. 29). In the present paper it is extended to include a similar unit in the Danish sector (fig. 4).

\section{Name:}

Named by Hesjedal \& Hamar (1983) after a village in southwestern Norway.

\section{Well type section:}

The Danish I-1 well from $9381 \mathrm{ft}$. to $9507 \mathrm{ft}$. b.KB 2822-2861 m b.MSL, fig. 26.

\section{Well reference section:}

2/11-1 (Norway): 9548 ft. - 9803 ft. b. KB, 2883-2961 m b.MSL.

E-1 (Denmark): 8162 ft. - 8218 ft. b.KB, 2451-2468 m b.MSL. See also fig. 29.

\section{Thickness:}

The thickness increases from around 15 to $30 \mathrm{~m}$ in the Salt Dome Province to $39 \mathrm{~m}$ in the $\mathrm{I}-1$ well in the ArneElin Graben and further to $78 \mathrm{~m}$ in the $2 / 11-1$ well in the Feda Graben (fig. 32). Fig. 31 is a map showing the thickness of the uppermost Lower Cretaceous seismic unit including the Sola Formation.

\section{Lithology:}

Black or dark grey, shaly and carbonaceous marlstone or claystone frequently containing fish debris; frequently finely laminated and generally very pyritic. Interbedded with layers (up to $10 \mathrm{~m}$ ) of light olive grey to brownish, burrowed marlstone and light grey chalk. Brick red colours may occur. Silt and sand are occasionally reported within this formation (figs. 26 and 27).

The content of organic carbon varies greatly; as much as $12 \%$ has been recorded. According to Hesjedal \& Hamar (1983) average values are c. $2 \%$.

\section{Log characteristics:}

The gamma ray values are significantly higher than in the formations above and below, although they do not reach values as high as in the Valhall Formation. The gamma ray oscillations are interpreted as the combined effect of fluctuations in the content of clay and of organic matter. The sonic velocity reflects these variations with lows in intervals with high gamma ray readings.

\section{Boundaries:}

The lower boundary is placed on top of the thick chalk sequence of the Tuxen Formation, i.e. where the gamma ray response increases from chalk level (see above). This is not in accordance with the practice of Hesjedal \& Hamar (1983). According to Hamar (pers. comm. 1985) they placed the lower boundary where the gamma ray values have grown to high values and the sonic velocity has decreased, i.e. slightly higher than mentioned above (fig. 24). The lowermost boundary is chosen because it marks the first appearence of beds with an increased content of clay and organic matter and consequently indicates a change in depositional environment from the mainly well oxygenated pelagic sediments of the Tuxen Formation to the clastic influenced and organic rich sediments of the Sola Formation.

The upper boundary is identical with the upper boundary of the Valhall Formation as defined by Deegan \& Scull (1977). It is placed where the last carbonaceous marlstone or claystone layer is present. On the gamma-sonic log it is characterized by a sudden or gradual decrease in gamma ray response and increase in sonic velocity (see fig. 29). Where the Rødby Formation is absent the upper boundary with the Chalk Group is marked by an abrupt decrease in gamma ray response and increase in sonic velocity. 


\section{Distribution:}

The formation is widespread in both the central and northern North Sea (Hesjedal \& Hamar 1983). In the Danish Central Trough it is present in all wells placed centrally in the basin but absent in some of the marginally situated wells and those situated on structural highs and salt structures (fig. 32).

This formation is time-equivalent to both the Lower Holland Marl Member and Middle Holland Shale Member. The former member is described as a marl interbedded with bituminous shales (NAM \& RGD 1980). Similar organic rich and time-equivalent sediments are present in the Helgoland-Schleswig Basin and the Lower Saxony Basin (Kemper \& Zimmerle 1978, and fig. 4).

Age:

According to Hesjedal \& Hamar (1983), the Sola Formation is of mid Aptian to Early Albian age; however, after new age determinations in Danish wells, and revision of the lower boundary, a Middle (-Late) Barremian to Albian age (locally Aptian) is suggested by Heilmann-Clausen (1986).

\section{Depositional environment:}

The sequence was deposited in a marine environment with alternating anoxic and oxic bottom conditions.

According to Hesjedal \& Hamar (1983) the Sola Formation was deposited in restricted basins created during a regressive period linked to the Austrian tectonic phase of mid Aptian age. Rawson \& Riley (1982) have the opposite view. They consider the Aptian as mainly transgressive with only minor regressions related to the Austrian tectonic phase. In the Danish sector a regressive phase cannot be traced seismically due to the limited thickness of the formation.

It must be admitted, though, that good evidences exist for a regression in the Aptian, such as the frequent occurrence of sand bodies along basin margins (NAM \& RGD 1980, Hesjedal \& Hamar 1983).

Nevertheless, with the revision of the lower boundary and the age of the Sola Formation, proving onset of deposition under anoxic conditions as early as in the Middle-Late Barremian, it is uncertain whether the establishment of anoxic conditions can be coupled to the Austrian phase at all.

The Sola Formation is time-equivalent to organic rich sediments encountered over large areas in the Atlantic Ocean. These sediments have been interpreted as deposited during what has been named a "Lower Cretaceous Anoxic Event" and during a time of transgression (e.g. Schlanger \& Jenkyns 1976, Scholle \& Ar- thur 1980, discussion in Kemper \& Zimmerle 1978).

A more comprehensive understanding of the factors which led to the establishment of anoxic conditions must await further investigations.

\section{Rødby Formation}

Defined by Larsen (1966) as a reddish marine marl formation encountered in the southern part of the Danish Subbasin and further south. The formation was extended by Deegan \& Scull (1977) to include similar sediments in the central North Sea.

The Rødby Formation is probably equivalent to the Red Chalk Formation of the southern British North Sea (Rhys 1974) and the Upper Holland Marl Member of the Dutch sector (NAM \& RGD 1980, and fig. 4).

Name:

Named by Larsen (1966) after a town at the island of Lolland in southern Denmark.

Well type section:

The Danish Rødby-1 well drilled at the island of Lolland (see Larsen 1966, pl. XV).

\section{Well reference sections:}

2/11-1 (Norway): 9473 ft. - 9548 ft. b.KB, 2861-2883 m b.MSL.

Bo-1 (Denmark): 7474 ft. - 7618 ft. b.KB, 2245-2289 m b.MSL.

See also fig. 27.

\section{Thickness:}

The formation is thin or absent in the Salt Dome Province, probably owing to erosion. It reaches a maximum thickness of $44 \mathrm{~m}$ in the reference well Bo-1 (fig. 32). Average thicknesses for the formation are in the order of 15 to $30 \mathrm{~m}$ in the central North Sea (Deegan \& Scull 1977).

\section{Lithology:}

Mainly red-brown marlstone, but light grey or greenish colours may occur and reddish colours alone cannot be considered a diagnostic feature. The marlstone may occasionally be sandy or silty, glauconitic and pyritic. The marlstone is interbedded with subordinate layers of 
limestone and claystone and it is generally burrowed and has a low content of organic carbon (c. $0.3 \%$ ) (Deegan \& Scull 1977, Hesjedal \& Hamar 1983).

\section{Log characteristics:}

On the gamma ray and sonic logs this formation is cha- racterized by an upward gradual decrease in gamma ray response and increase in sonic velocity with only minor fluctuations. On the neutron-density logs this pattern is reflected as a gradual decrease in the separation between the two logs.

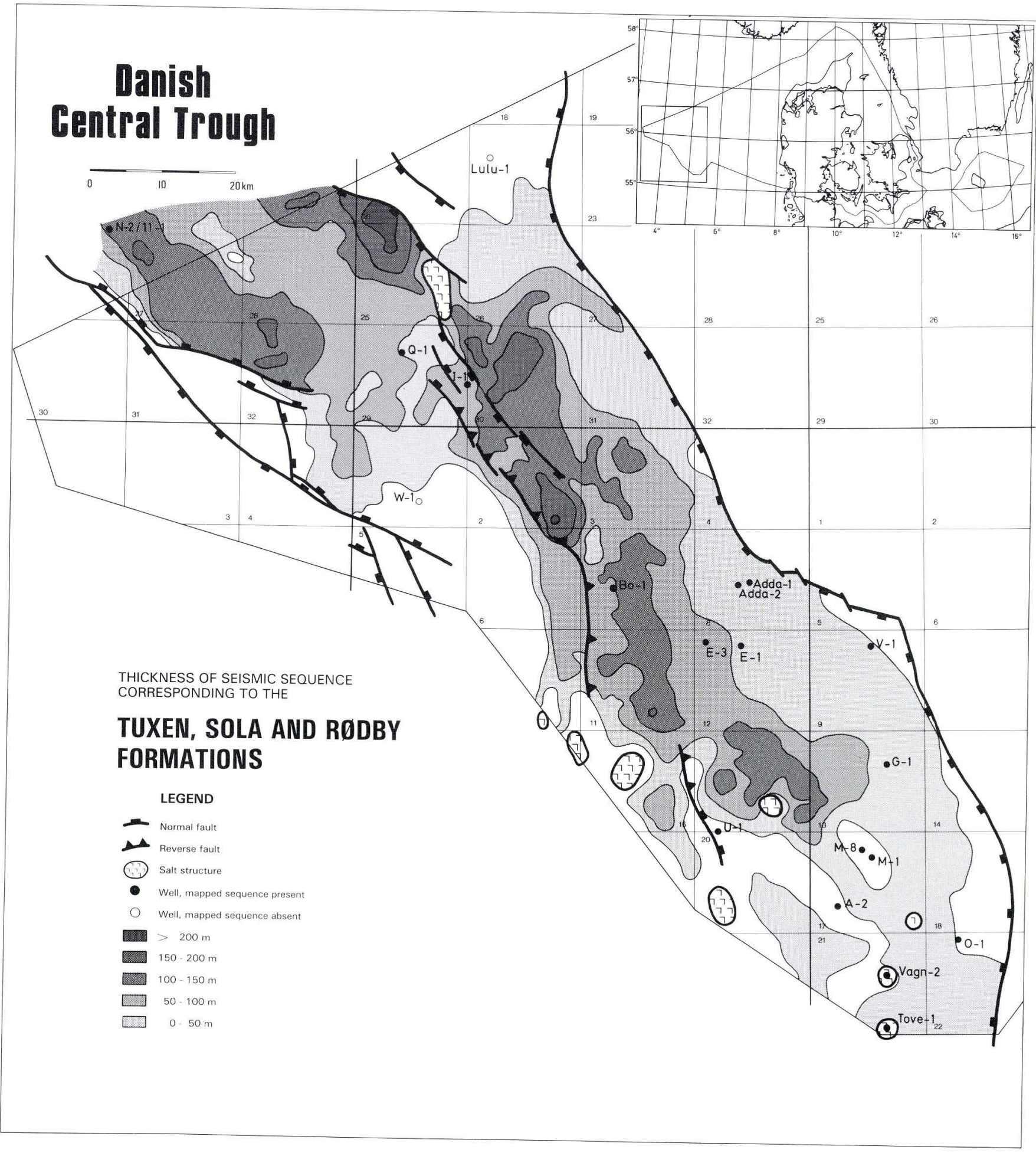
Fig. 31: Thickness and distribution of the seismic sequence corresponding to the Tuxen, Sola and Rødby Formations (by Ole Val-
demar Vejbcek). 


\section{Boundaries:}

The lower boundary is described above under the Sola Formation. The upper boundary with the Chalk Group is often characterized by a minor but distinct drop in gamma ray values simultaneous with a marked increase in sonic velocity (e.g. Adda-2, I-1, fig. 29). In these wells the boundary corresponds to an unconformity between the Cromer Knoll Group and the Chalk Group.
In other wells, where deposition is assumed to have been continuous across the Early-Late Cretaceous boundary, the boundary is more ambiguous. In these wells the boundary is chosen at a depth where constant low gamma ray readings and high sonic velocity characteristic for the Chalk Group are achieved (e.g. Bo-1, fig. 29).

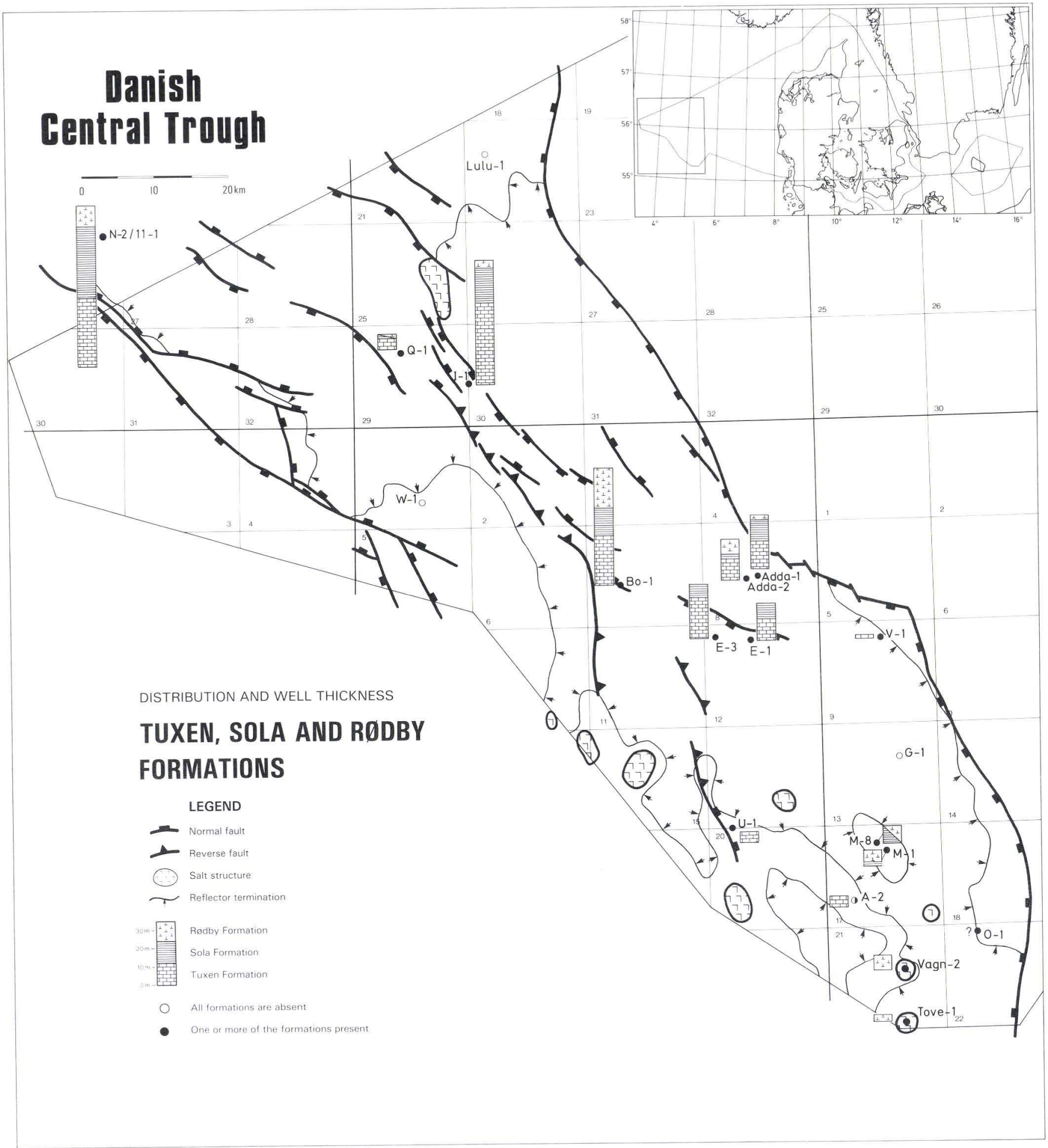

Fig. 32: Extension of the seismic sequence corresponding to the Tuxen, Sola and Rødby Formations (modified from Vejbak 1986). Distribution and thickness of the Tuxen, Sola and Rødby Formations as encountered in wells. 


\section{Distribution:}

The formation is absent in most wells in the Salt Dome Province. Otherwise, the formation is assummed to be present in most basins within the Danish Central Trough (fig. 32). Its distribution on a more regional scale is outlined by Deegan \& Scull (1977), Hesjedal \& Hamar (1983) and Rawson \& Riley (1982).

Age:

The formation is dated palynologically as being of Albian age (Heilmann-Clausen 1986) locally Early Cenomanian

\section{Depositional environment:}

Deposited in a marine environment with reduced clastic supply. For unknown reasons the deposition of the organic rich Sola Formation sediments terminated and instead, deposition of the oxygenated and generally reddish sediments of the Rødby Formation took over. The supply of clastic material gradually decreased as a result of a continuous transgression. Ultimately the clastic influx was totally masked by the production of pelagic carbonate as evidenced by the lithofacies change at the boundary between the Cromer Knoll Group and the Chalk Group (see also Hesjedal \& Hamar 1983, Rawson \& Riley 1982).
LITHOLOGICAL LEGEND

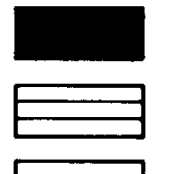

Coal

Clay/claystone

- - Silt/siltstone

$\therefore \ldots \ldots$ Sand/sandstone

$\circ \quad 0$ Scattered gravel grains

$\because \because$ Claystone rich in organic carbon

대대대 Limestone

Limestone bands

Dolomite bands

$\perp \perp \perp$ Marlstone

Marlstone rich in organic carbon

Anhydrite

Fig. 33: Lithological legend for type and reference sections. 


\section{Acknowledgements}

The work forming the basis for the present paper has been carried out as a part of a project study financially supported by the Ministry of Energy. The late Prof. Tove Birkelund and lic. scient. Stefan Piasecki have provided help and advice during the project work. Prof. Finn Surlyk and cand. scient. Peter Gravesen have carefully read the manuscript and suggested many improvements. Our heartiest thanks go to these colleagues who in this way have helped to increase the quality of the paper.

Dr. Georg Hamar and his colleagues at Statoil are thanked for fruitfull discussions concerning the Jurassic and the Lower Cretaceous lithostratigraphy, Dr. Ed- win Kemper at Bundesanstalt für Geowissenschafte und Rohstoffe for the lithostratigraphy of the Lower Saxony Basin and Mærsk Olie og Gas A/S for releasing the data from the Adda-2 well.

Dr. Richard Bromley is thanked for correcting the English manuscript. Helle Zetterwall, Liselotte Thorsen and Birgitte Enig have produced the drawings, and Pia Andersen and Dorthe Plougmann typed the manuscript.

We thank all those mentioned above together with those not mentioned who assisted us with discussion, information and comments. 


\section{References}

Bertelsen, F. 1978: The Upper Triassic - Lower Jurassic Vinding and Gassum Formations of the Norwegian-Danish Basin. Danm. Geol. Unders., Ser. B, 3, $26 \mathrm{pp}$

Birkelund, T., Clausen, C.L., Hansen, H.N. \& Holm, L. 1983: The Hectoroceras kochi zone (Ryazanian) in the North Sea Central Graben and remarks on the Late Cimmerian Unconformity. Danm. geol. Unders., Årbog 1982, pp. 53-73.

Bromley, R.G. \& Ekdale, A.A. 1984: Chondrites: A trace fossil indicator of anoxia in sediments. Science, 224, pp. 872-874.

Casey, R. \& Rawson, P.F. 1973: A review of the Boreal Lower Cretaceous. - In: Casey, R. \& Rawson, P.F. (eds.): The Boreal Lower Cretaceous. Geol. J. Spec. Iss., 5, pp. 415-430.

Crittenden, S. 1982: Lower Cretaceous lithostratigraphy NE of the Sole Pit Area in the UK southern North Sea. Jour. Petr. Geology, 5 (2), pp. 191-202.

Deegan, C.E. \& Scull, B.J. (compilers) 1977: A standard lithostratigraphic nomenclature for the central and northern North Sea. Rep. Inst. Geol. Sci., No.77/25.

Doré, A.G., Vollset, J. \& Hamar, G.P. 1985: Correlation of the offshore sequences referred to the Kimmeridge Clay Formation - relevance to the Norwegian sector. - In: Thomas, B.M. et al. (eds.) Petroleum Geochemistry in exploration of the Norwegian shelf. Norw. Petr. Society, Graham \& Trotmann Ltd. pp. 27-37.

Folk, R.L., 1962: Spectral subdivision of limestone types. - In: Ham W.E. (ed.): Classification of carbonate rocks, - a symposium. AAPG memoir 1, pp. 62-84

Frandsen, N., 1986: Middle Jurassic deltaic and coastal deposits in the Lulu-1 well, Danish Central Trough. Danm. geol. Unders., Ser. A, (in press).

Frandsen, N., Hoelstad, T. \& Mikkelsen, N., 1985: Middle Jurassic of the Danish Central Graben. - In: Michelsen, O. (ed.): Symposium on Jurassic - L. Cretaceous of the Central Graben, November 1984. Danm. geol. Unders., Internal report no. 6, pp. 6-19.

Gowers, M.B. \& Sxbøe, A. 1985: On the structural evolution of the Central Trough in the Norwegian and Danish sectors of the North Sea. Marine and Petrol. Geol., 2, pp. 298-317.

Hamar, G.P., Fjæran, T. \& Hesjedal, A. 1983: Jurassic stratigraphy and tectonics of the south-southeastern Norwegian offshore. - In: Kaasschieter, J.P.H. \& Reijers, T.J.A. (eds.): Petroleum geology of the southeastern North Sea and the adjacent onshore areas. Geol. Mijnbouw, 62, pp. 103-114.

Hansen, J.M. \& Buch, A., 1982: Early Cretaceous. - In: Michelsen, $O$. (ed.): Geology of the Danish Central Graben. Danm. geol. Unders., Ser. B, 8, pp. 45-49.

Hedberg, H.D. (ed.), 1976: International stratigraphic guide: A guide to stratigraphic classification, terminology and procedure. Int. Subcommission on Stratigraphic Classification of IUGS Commission on Stratigraphy. New York, Wiley \& Sons

Heilmann-Clausen, C., 1986: Lower Cretaceous dinoflagellate biostratigraphy in the Danish Central Trough. Danm. geol. Unders., Ser. A, (in prep.).

Herngreen, G.F.W. \& de Boer, K.F., 1984: Palynology of the "Upper Jurassic" Central Graben, Scruff and Delfland Groups in the Dutch part of the North Sea continental shelf. - In: Michelsen, $O$. \& Zeiss, A. (eds.): International Symposium on Jurassic stratigraphy. Erlangen, pp. 695-714.

Hesjedal, A. \& Hamar, G.P., 1983: Lower Cretaceous stratigraphy and tectonics of the south-southeastern Norwegian offshore. - In: Kaasschieter, J.P.H. \& Reijers, T.J.A. (eds.): Petroleum Geology of the southeastern North Sea and the adjacent onshore areas. Geol. Mijnbouw, 62, pp. 135-144.
Hoclstad, T., 1986a: Palynology and palynofacies analysis of the Middle Jurassic to Lower Cretaceous in the Danish Central Trough. Danm. geol. Unders., (internal report).

Hoelstad, T., 1986b: Palynology of the Middle Jurassic Lower Graben Sand Formation of the U-1 well, Danish Central Trough. Danm. geol. Unders., Ser. A, (in press).

Jacobsen, F., 1982: Triassic. - In: Michelsen, O. (ed.): Geology of the Danish Central Graben. Danm. geol. Unders., Ser. B, 8, pp. 32-36.

Johnson, H.D. \& Stewart, D.J., 1985: The role of clastic sedimentology in the exploration and production of oil and gas in the North Sea. - In: Brenchley, P.J. \& Williams, B.P.J. (eds.): Sedimentology: Recent developments and applied aspects. Blackwell Scientific Publications, Oxford, pp. 249-310.

Kemper, E., 1973a: The Aptian and Albian stages in Northwest Germany. - In: Casey, R. \& Rawson, P.F. (eds.): The Boreal Lower Cretaceous. Geol. Jour. Spec. Is., no. 5, pp. 345-360.

Kemper, E., 1973b: The Valanginian and Hauterivian stages in Northwest Germany. - In: Casey, R. \& Rawson, P.F. (eds.): The Boreal Lower Cretaceous. Geol. Jour. Spec. Is., no. 5, pp. 327343.

Kemper, E., 1979: Die Unterkreide Nordwestdeutschlands - Ein Überblick. - In: Wiedmann, J. (ed.): Aspekte der Kreide Europas. Int. Un. Geol. Sc., Ser. A, no. 6, pp. 1-9.

Kemper, E. \& Zimmerle, W., 1978: Die anoxischen Sedimente der präoberaptischen Unterkreide NW-Deutschlands und ihr paläogeographischer Rahmen. Geol. Jahrb. Reihe A, 45, pp. 3-41.

Koch, J.O., 1983: Sedimentology of Middle and Upper Jurassic sandstone reservoirs of Denmark. - In: Kaasschieter, J.P.H. \& Reijers, T.J.A. (eds.): Petroleum geology of the southeastern North Sea and the adjacent onshore areas. Geol. Mijnbouw, 62, pp. 115-129.

Koch, J.O., Holm, L. \& Michelsen, O., 1982: Jurassic. - In: Michelsen, O. (ed.): Geology of the Danish Central Graben. Danm. geol. Unders., Ser. B, 8, pp. 37-45.

Larsen, G., 1966: Rhaetic-Jurassic-Lower Cretaceous Sediments in the Danish Embayment (A Heavy-Mineral Study). Danm. geol. Unders., II Rk., 91, 128 pp.

Lindgreen, H., Thomsen, E. \& Wrang, P., 1982: Source rocks. - In: Michelsen, O., (ed.): Geology of the Danish Central Graben. Danm. geol. Unders., Ser. B, 8, pp. 73-86.

Michelsen, O., 1978a: Stratigraphy and distribution of Jurassic deposits of the Norwegian-Danish Basin. Danm. geol. Unders., Ser. B, 2, 35 pp.

Michelsen, O., 1978b: The Lower Jurassic of the Dansk Nordsø O-1 boring, Central Trough. Danm. geol. Unders., Årbog 1977, pp. 77-89.

Michelsen, O. (ed.), 1982: Geology of the Danish Central Graben Danm. geol. Unders., Ser. B, 8, 133 pp.

Michelsen, O., Holm, L. \& Frandsen, N., 1984: Stratigraphy of the Danish Jurassic sequence. - In: Michelsen, O. \& Zeiss, A. (eds.): International symposium on Jurassic stratigraphy. Erlangen, pp. 755-766.

Møller, J.J., 1986: Seismic structural mapping of the Middle and Upper Jurassic in the Danish Central Trough. Danm. geol. Unders., Ser. A, (in prep.).

NAM \& RGD (Nederlandse Aardolie Maatschappij B.V. \& Rijks Geologische Dienst), 1980: Stratigraphic nomenclature of the Netherlands. Verh. van het Koninklijk Ned. Geologisch Mijnbouwkundig Genootschap, 32, 77 pp.

Olsen, R.C. \& Strass, I.F., 1982: The Norwegian-Danish Basin. NPD Páper no. $31,76 \mathrm{pp}$. 
Poulsen, N.E., 1986: Callovian (Jurassic) to Ryazanian (Cretaceous) dinoflagellate biostratigraphy of the Danish Central Trough. Danm. geol. Unders., Ser. A, (in prep.)

Rasmussen, L.B., 1974: Some geological results from the first five Danish exploration wells in the North Sea. Danm. geol. Unders. III, Rk., 42, 46 pp.

Rasmussen, L.B., 1978: Geological aspects of the Danish North Sea sector. Danm. geol. Unders., III Rk., 44, 85 p.

Rawson, P.F., Curry, D., Dilley, F.C., Hancock, J.M., Kennedy, W.J., Neale, J.W., Wood, C.J. \& Worssam, B.C., 1977: A correlation of Cretaceous rocks in the British Isles. Geol. Soc. London Spec. Rep., no. 9, 70 pp.

Rawson, P.F. \& Riley, L.A., 1982: Latest Jurassic-Early Cretaceous Events and the "Late Cimmerian Unconformity" in the North Sea Area. AAPG Bull., 66 (12), pp. 2628-2648.

Rhys, G.H., 1974: A proposed standard lithostratigraphic nomenclature for the southern North Sea and an outline structural nomenclature for the whole of the (U.K.) North Sea. Inst. Geol. Sci., Report 74/8, 14 pp.

Riley, L.A., 1977: Stage nomenclature at the Jurassic-Cretaceous boundary, North Sea Basin. - In: Finstad, K.G. \& Selley, R.C. (eds.): Mesozoic northern North Sea Symposium. Norw. Petr. Society, Stavanger, pp. 1-11.

Rønnevik, H.C., van den Bosch, W. \& Bandlien, E.H., 1975: A proposed nomenclature for the main structural features in the Norwegian North Sea. - In: Finstad, K.G. \& Selley, R.C. (eds.): Jurassic northern North Sea Symposium. Norw. Petr. Society, Stavanger, pp. 1-16.

Schlanger, S.O. \& Jenkyns, H.C., 1976: Cretaceous anoxic events: Causes and consequences. Geol. Mijnbouw, 55 (3-4), pp. 179-184

Scholle, P.A. \& Arthur, N.A., 1980: Carbon isotope fluctuations in Cretaceous pelagic limestone: Potential stratigraphic and petroleum exploration tool. AAPG Bull., 64 (1), pp. 67-87.
Schott, W., 1969: Paläogeographischer Atlas der Unterkreide von Nordwestdeutschland mit einer Übersichtsdarstellung des nördlichen Mitteleuropa. Bundesanstalt für Bodenforschungen, Hannover, $315 \mathrm{pp}$.

Stow, D.A.V., 1984: Upper Jurassic overlapping-fans slope-apron system: Brae Oilfield, North Sea. Geo-Marine Letters, 3, pp. 217 222.

Thomsen, E., Lindgreen, H. \& Wrang, P., 1983: Investigation on the source rock potential of Denmark. - In: Kaasschieter, J.P.H. \& Reijers, T.J.A. (eds.): Petroleum geology of the southeastern North Sea and the adjacent onshore areas. Geol. Mijnbouw, 62, pp. 221-239.

Thomsen, E., 1986: Lower Cretaceous nannofossil biostratigraphy in the Danish Central Trough. Danm. geol. Unders., Ser. A. (in prep.).

Vail, P.R. \& Todd, R.G., 1981: Northern North Sea Jurassic unconformities, chronostratigraphy and sea-level changes from seismic stratigraphy. - In: Illing, L.V. \& Hobson, G.D. (eds.): Petroleum geology of the continental shelf of Northwest Europe. The Institute of Petroleum, London, pp. 216-235.

Vejbæk, O.V., 1986: Seismic stratigraphy of the Lower Cretaceous in the Danish Central Trough. Danm. geol. Unders., Ser. A, (in press).

Vollset, J. \& Doré, A.G. (eds.), 1984: A revised Triassic and Jurassic lithostratigraphic nomenclature for the Norwegian North Sea. NPD-Bulletin no. 3, Stavanger, 53 pp.

Wood, C.J. \& Smith, E.G., 1978: Lithostratigraphical classification of the chalk in North Yorkshire, Humberside and Lincolnshire. Proc. Yorkshire Geol. Soc., 42 (14), pp. 263-287.

Ziegler, P.A., 1982: Geological Atlas of Western and Central Europe. Elsevier, Amsterdam, 130 pp. 


\section{Lithostratigraphic table}

\section{Legend}

$\log$ Wire line logs used for identification of the boundary

/ Upper/lower boundary

ITT Interval transit time

GR Gamma ray

FDC Compensated formation density

CNL Compensated neutron log

KB Kelly bushing

MSL Mean sea level

TD Total depth of the well

$+\quad$ Minimum thickness

Thickness: The "thickness" of lithostratigraphic units is calculated from "depths in feet b. KB".

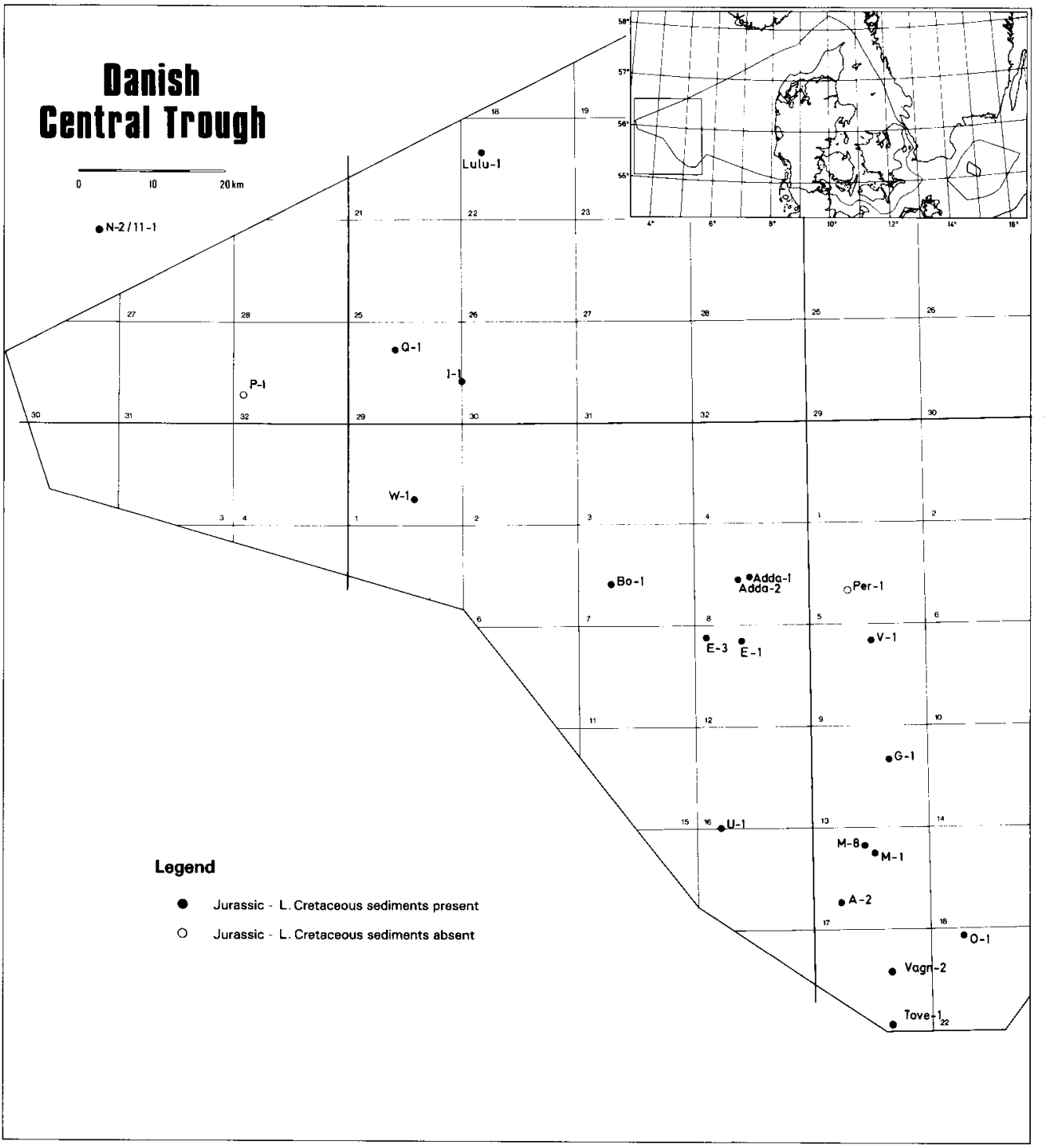


Fjerritslev Formation

\begin{tabular}{llll}
\hline Well & $\begin{array}{l}\text { Depth b.KB } \\
\text { (feet) }\end{array}$ & $\begin{array}{l}\text { Log } \\
\text { (characterizing) }\end{array}$ & $\begin{array}{l}\text { Depth b.MSL } \\
(\mathrm{m})\end{array}$ \\
\hline A-2 & absent & $\begin{array}{l}\text { Thickness } \\
(\mathrm{m})\end{array}$ \\
Adda-1 & not drilled & & \\
Adda-2 & not drilled & & \\
Bo-1 & not drilled & & \\
E-1 & not drilled & & \\
E-3 & not drilled & & \\
G-1 & not drilled & & $3161-3253$ \\
I-1 & absent & & $2968-3126$ \\
Lulu-1 & not drilled & & \\
M-1 & $10467-10771$ & GR-ITT/ITT-GR & \\
M-8 & $9830-10347$ & GR-(ITT)/ITT-GR & \\
O-1 & absent & & $3342-3388$ \\
Q-1 & absent & & \\
Tove-1 & absent & & \\
U-1 & absent & (GR)/GR-ITT & \\
V-1 & absent & & \\
Vagn-2 & & & \\
W-1 & & & \\
\hline
\end{tabular}

\section{Bryne Formation}

\begin{tabular}{llll}
\hline Well & $\begin{array}{l}\text { Depth b.KB } \\
\text { (feet) }\end{array}$ & $\begin{array}{l}\text { Log } \\
\text { (characterizing) }\end{array}$ & $\begin{array}{l}\text { Depth b.MSL } \\
(\mathrm{m})\end{array}$ \\
\hline A-2 & absent & & $\begin{array}{l}\text { Thickness } \\
(\mathrm{m})\end{array}$ \\
Adda-1 & not drilled & & \\
Adda-2 & not drilled & & \\
Bo-1 & not drilled & & \\
E-1 & not drilled & & \\
E-3 & not drilled & & $3540-3669$ \\
G-1 & not drilled & & \\
I-1 & not drilled & & \\
Lulu-1 & 11712-12134 & & \\
M-1 & not drilled & & \\
M-8 & absent & & \\
O-1 & absent & & \\
Q-1 & absent & & \\
Tove-1 & absent & & \\
U-1 & absent & & \\
V-1 & absent & & \\
Vagn-2 & absent & absent & \\
W-1 & & & \\
\hline
\end{tabular}


Lower Graben Sand Formation

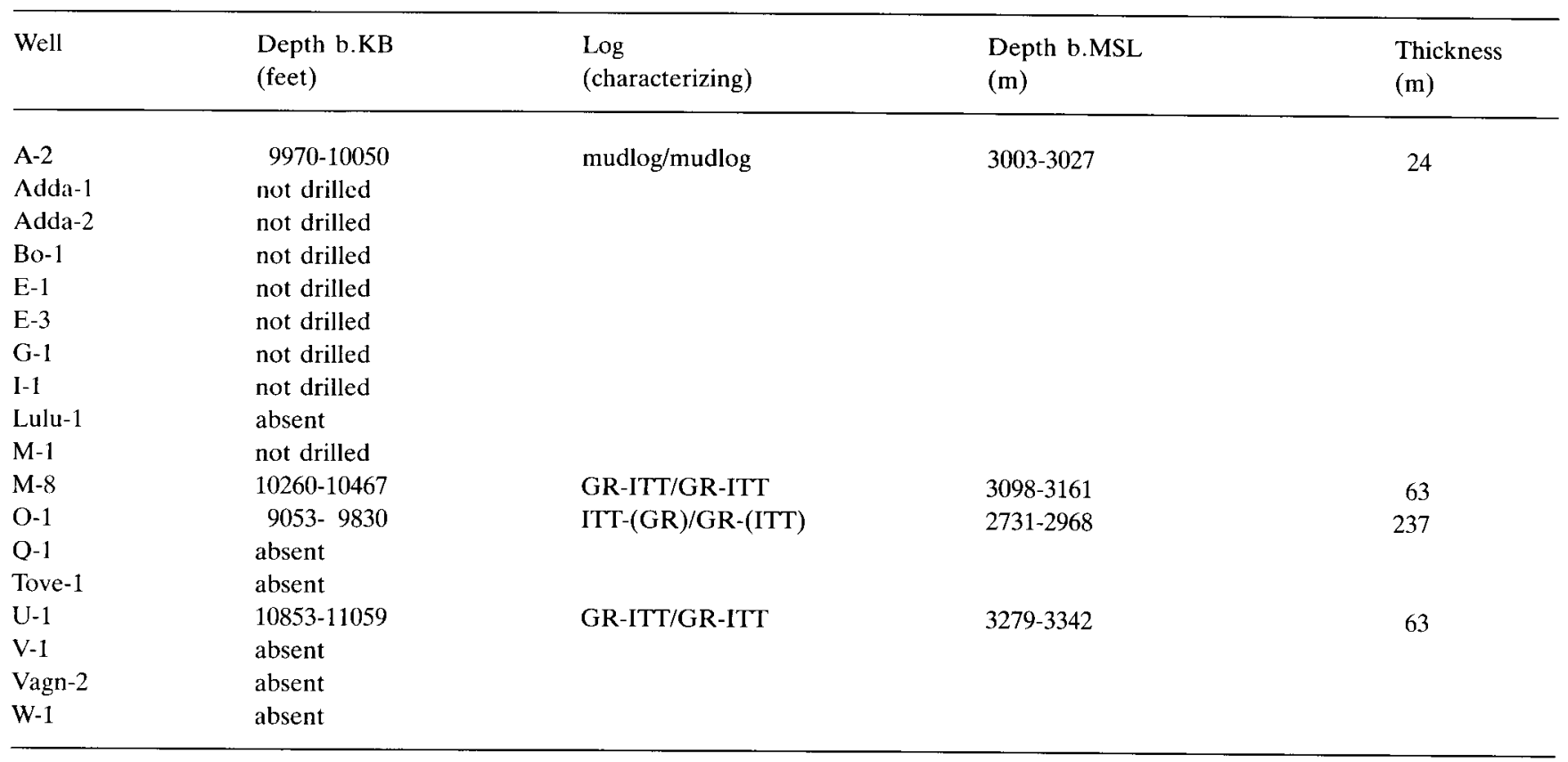

\section{Middle Graben Shale Formation}

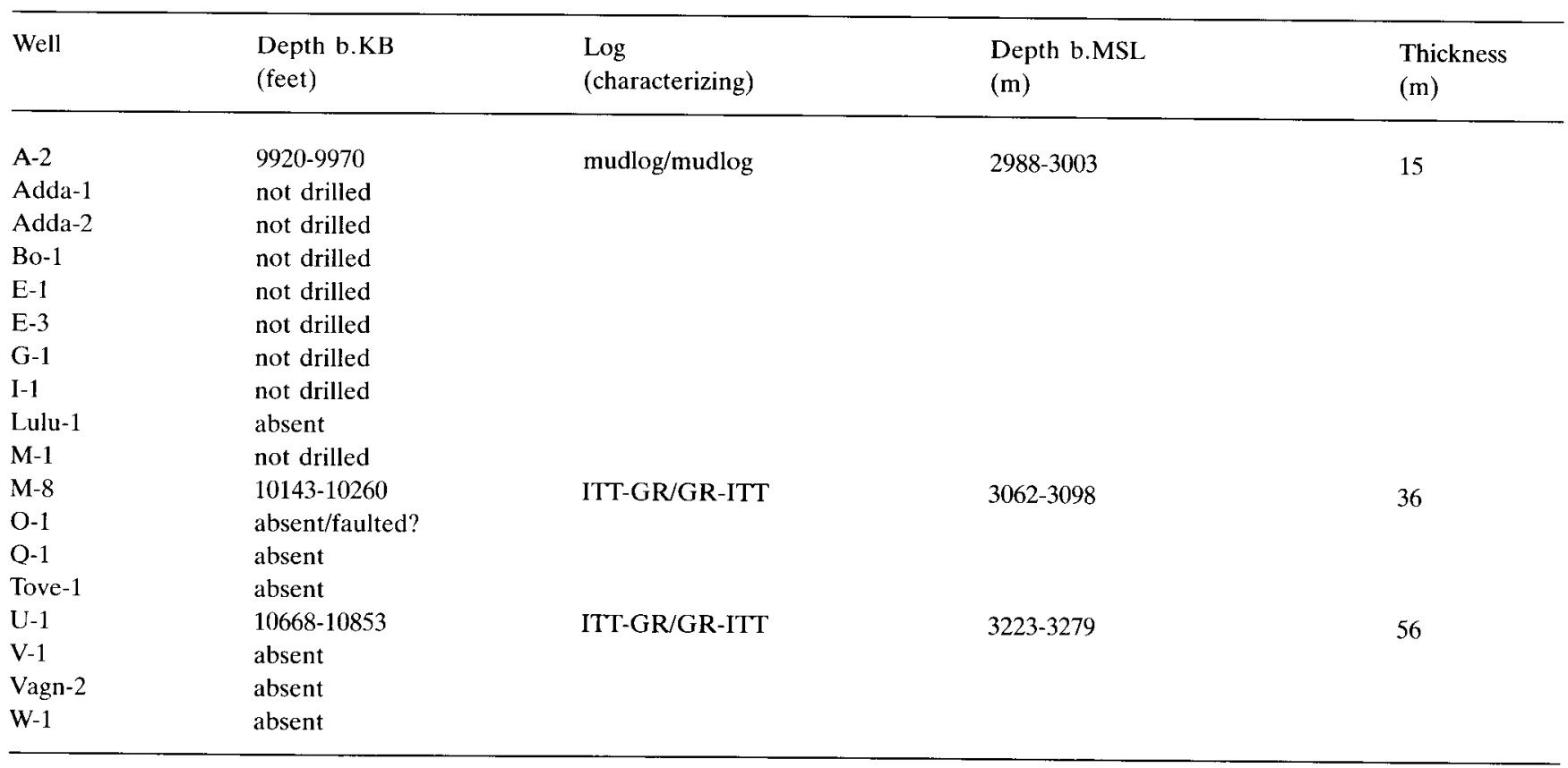




\section{Lola Formation}

\begin{tabular}{|c|c|c|c|c|}
\hline Well & $\begin{array}{l}\text { Depth b.KB } \\
\text { (feet) }\end{array}$ & $\begin{array}{l}\text { Log } \\
\text { (characterizing) }\end{array}$ & $\begin{array}{l}\text { Depth b.MSL } \\
\text { (m) }\end{array}$ & $\begin{array}{l}\text { Thickness } \\
\text { (m) }\end{array}$ \\
\hline$A-2$ & ?- 9920 & mudlog & $?-2988$ & \\
\hline Adda-1 & not drilled & & & \\
\hline Adda-2 & not drilled & & & \\
\hline Bo-1 & not drilled & & & \\
\hline E-1 & not drilled & & & \\
\hline E-3 & not drilled & & & \\
\hline G-1 & not drilled & & & \\
\hline $1-1$ & not drilled & & & \\
\hline Lulu-1 & $11373-11712$ & ITT/GR-ITT & $3437-3540$ & 103 \\
\hline M-1 & not drilled & & & \\
\hline M-8 & $8951-10143$ & ITT-GR/ITT-(GR) & $2699-3062$ & 363 \\
\hline O-1 & $8510-9053$ & GR/ITT-(GR) & $2566-2731$ & 166 \\
\hline Q-1 & $13608-13906$ & ITT/ITT & $4110-4201$ & 91 \\
\hline Tove-1 & absent & & & \\
\hline U-1 & $9555-10668$ & ITT-(GR)/ITT & $2884-3223$ & 339 \\
\hline V-1 & $11267-12071$ & ITT-GR/ITT & $3401-3646$ & 245 \\
\hline Vagn-2 & absent & & & \\
\hline$W-1$ & absent & & & \\
\hline
\end{tabular}

\section{Heno Formation}

\begin{tabular}{lllll}
\hline Well & $\begin{array}{l}\text { Depth b.KB } \\
\text { (feet) }\end{array}$ & $\begin{array}{l}\text { Log } \\
\text { (characterizing) }\end{array}$ & $\begin{array}{l}\text { Depth b.MSL } \\
\text { (m) }\end{array}$ & $\begin{array}{l}\text { Thickness } \\
(\mathrm{m})\end{array}$ \\
\hline A-2 & absent & & \\
Adda-1 & not drilled & & \\
Adda-2 & not drilled & & \\
Bo-1 & not drilled & & \\
E-1 & not drilled & & \\
E-3 & not drilled & & \\
G-1 & not drilled & & \\
I-1 & not drilled & & \\
Lulu-1 & absent & & $4056-4110$ \\
M-1 & not drilled & & \\
M-8 & absent & & \\
O-1 & absent & & \\
Q-1 & 13431-13608 & & \\
Tove-1 & absent & & \\
U-1 & absent & ITT/ITT & $4087-4178$ \\
V-1 & absent & & \\
Vagn-2 & absent & & \\
W-1 & 13520-13820 & & \\
\hline
\end{tabular}




\section{Farsund Formation}

\begin{tabular}{|c|c|c|c|c|}
\hline Well & $\begin{array}{l}\text { Depth b.KB } \\
\text { (feet) }\end{array}$ & $\begin{array}{l}\text { Log } \\
\text { (characterizing) }\end{array}$ & $\begin{array}{l}\text { Depth b.MSL } \\
\text { (m) }\end{array}$ & $\begin{array}{l}\text { Thickness } \\
\text { (m) }\end{array}$ \\
\hline A-2 & $7390-?$ & mudlog & $2217-?$ & \\
\hline Adda-1 & $8478-10005(\mathrm{TD})$ & ITT-GR/- & $2550-3015$ & $465+$ \\
\hline Adda-2 & $?$ & & & \\
\hline Bo-1 & 8348- 8998(TD) & GR-ITT/- & $2511-2709$ & $198+$ \\
\hline E-1 & 9726-13408(TD) & ITT-GR/- & $2927-4050$ & $1122+$ \\
\hline $\mathrm{E}-3$ & not drilled & & & \\
\hline G-1 & $7863-12526(\mathrm{TD})$ & GR-ITT/- & $2359-3781$ & $1421+$ \\
\hline $\mathrm{I}-1$ & $11018-12848(\mathrm{TD})$ & ITT-GR/- & $3321-3879$ & $558+$ \\
\hline Lulu-1 & $10643-11373$ & GR-ITT/ITT & $3214-3437$ & 223 \\
\hline M-1 & 7190- 7562(TD) & ITT-GR/- & $2158-2271$ & $113+$ \\
\hline M-8 & $7514-8951$ & ITT/ITT-GR & $2261-2699$ & 438 \\
\hline O-1 & $7820-8510$ & GR/GR & $2355-2566$ & 210 \\
\hline Q-1 & 13139-13431 & GR-ITT/ITT & $3967-4056$ & 89 \\
\hline Tove-1 & absent & & & \\
\hline $\mathrm{U}-1$ & $8190-9555$ & ITT-GR/ITT(GR) & $2468-2884$ & 416 \\
\hline V-1 & $9116-9356$ & ITT-GR/GR-ITT-FDC-CNL & $2745-2818$ & 73 \\
\hline Vagn-2 & $\begin{array}{c}+9463-11267 \\
\text { absent }\end{array}$ & GR-ITT-FDC-CNL/ITT-GR & $+2851-3401$ & +550 \\
\hline W-1 & $12335-13520$ & GR-ITT/ITT-GR & $3726-4087$ & 361 \\
\hline
\end{tabular}

\section{Hot unit}

\begin{tabular}{lllll}
\hline Well & $\begin{array}{l}\text { Depth b.KB } \\
\text { (feet) }\end{array}$ & $\begin{array}{l}\text { Log } \\
\text { (characterizing) }\end{array}$ & $\begin{array}{l}\text { Depth b.MSL } \\
(\mathrm{m})\end{array}$ & $\begin{array}{l}\text { Thickness } \\
(\mathrm{m})\end{array}$ \\
\hline A-2 & ? absent & & & \\
Adda-1 & absent & & & \\
Adda-2 & absent & & $2537-2576$ & 39 \\
Bo-1 & $8434-8561$ & GR/GR & $2940-2966$ \\
E-1 & 9771- 9853 & GR/GR & \\
E-3 & not drilled & & $3341-3408$ & \\
G-1 & absent $(?)$ & GR/GR & \\
I-1 & 11082-11304 & & \\
Lulu-1 & absent & & \\
M-1 & absent & & \\
M-8 & absent & & \\
O-1 & absent & & \\
Q-1 & absent & & \\
Tove-1 & absent & & \\
U-1 & absent & & \\
V-1 & absent & & \\
Vagn-2 & absent & & \\
W-1 & & & \\
\hline
\end{tabular}


Poul Formation

\begin{tabular}{lllll}
\hline Well & $\begin{array}{l}\text { Depth b.KB } \\
\text { (feet) }\end{array}$ & $\begin{array}{l}\text { Log } \\
\text { (characterizing) }\end{array}$ & $\begin{array}{l}\text { Depth b.MSL } \\
(\mathrm{m})\end{array}$ & $\begin{array}{l}\text { Thickness } \\
(\mathrm{m})\end{array}$ \\
\hline A-2 & ? absent & & \\
Adda-1 & absent & ? absent \\
Adda-2 & absent & & \\
Bo-1 & absent & & \\
E-1 & not drilled & & \\
E-3 & absent & & \\
G-1 & absent & & \\
I-1 & absent & & \\
Lulu-1 & absent & & \\
M-1 & absent & & \\
M-8 & absent & & \\
O-1 & absent & & \\
Q-1 & absent & & \\
Tove-1 & absent & & \\
U-1 & 9356-9463 & & \\
V-1 & absent & & \\
Vagn-2 & absent & GR-ITT-FDC-CNL/ & \\
W-1 & & GR-ITT-FDC-CNL & \\
\hline
\end{tabular}

\section{Cromer Knoll Group}

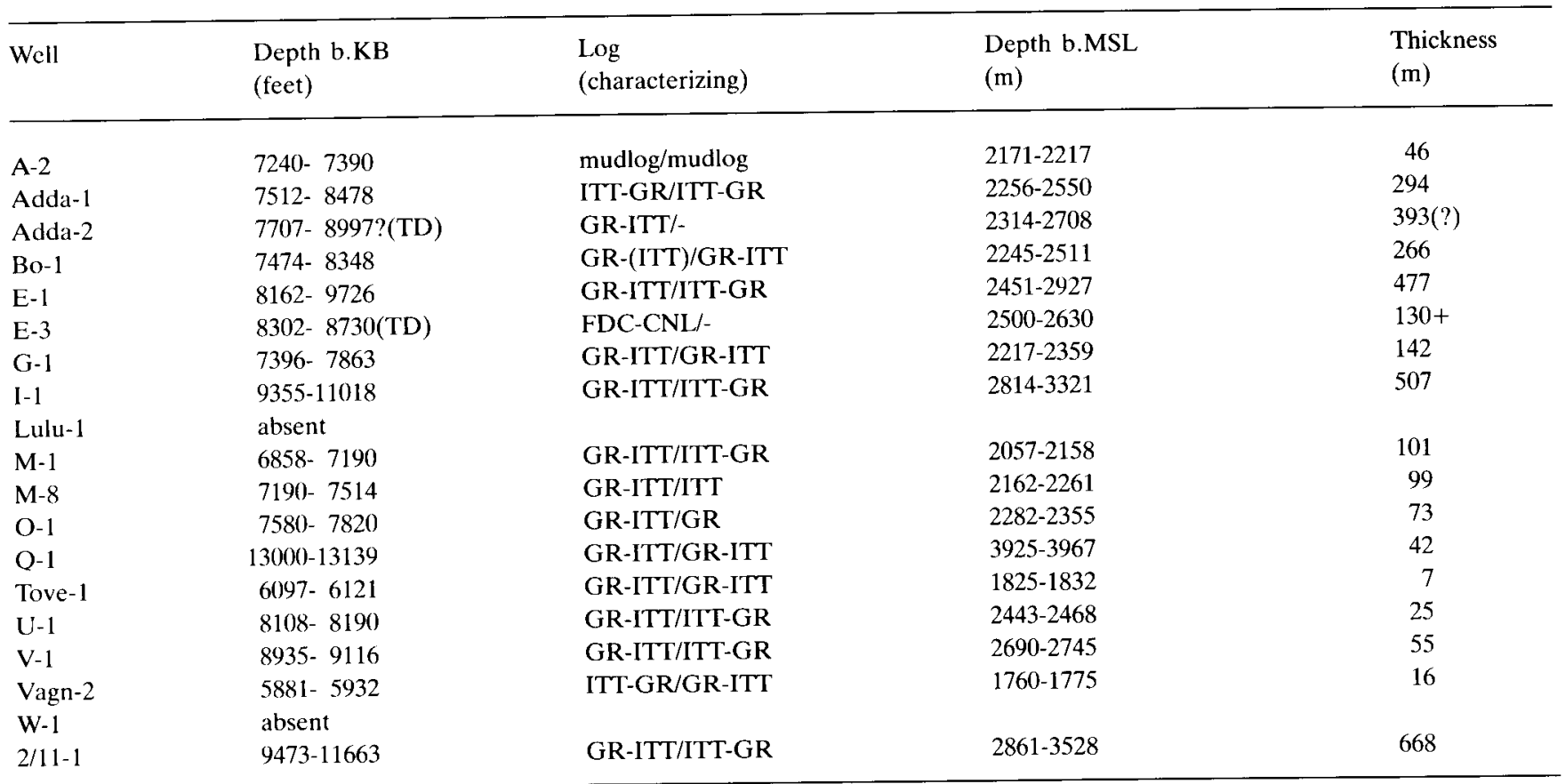


Valhall Formation

\begin{tabular}{|c|c|c|c|c|}
\hline Well & $\begin{array}{l}\text { Depth b.KB } \\
\text { (feet) }\end{array}$ & $\begin{array}{l}\text { Log } \\
\text { (characterizing) }\end{array}$ & $\begin{array}{l}\text { Depth b.MSL } \\
\text { (m) }\end{array}$ & $\begin{array}{l}\text { Thickness } \\
\text { (m) }\end{array}$ \\
\hline A-2 & $7280-7390$ & mudlog/mudlog & $2183-2217$ & 34 \\
\hline Adda-1 & $7700-8478$ & GR-ITT/ITT-GR & $2.313-2.550$ & 237 \\
\hline Adda-2 & 7854- 8997?(TD) & GR-ITT/- & $2359-2708$ & $348(?)$ \\
\hline Bo-1 & $7896-8348$ & GR-(FDC-CNL)/GR-ITT & $2373-2511$ & 138 \\
\hline E-1 & $8296-9726$ & GR-ITT/ITT-GR & $2491-2927$ & 436 \\
\hline $\mathrm{E}-3$ & $8497-8730(\mathrm{TD})$ & GR-ITT/- & $2559-2630$ & 71 \\
\hline G-1 & $7396-7863$ & GR-ITT/GR-ITT & $2217-2359$ & 142 \\
\hline I-1 & $9798-11018$ & GR-ITT/ITT-GR & $2949-3321$ & 372 \\
\hline Lulu-1 & absent & & & \\
\hline M-1 & $6915-7190$ & GR-ITT/ITT-GR & $2074-2158$ & 84 \\
\hline M-8 & 7253- 7514 & GR/ITT & $2181-2261$ & 80 \\
\hline $\mathrm{O}-1$ & $?$ & & & \\
\hline Q-1 & $13050-13139$ & GR/GR-ITT & $3940-3967$ & 27 \\
\hline Tove-1 & absent & & & \\
\hline $\mathrm{U}-1$ & $8150-8190$ & GR-ITT/ITT-GR & $2456-2468$ & 12 \\
\hline V-1 & 8945- 8974 & GR-ITT/GR-ITT & $2693-2702$ & 9 \\
\hline Vagn-2 & absent & & & \\
\hline W-1 & absent & & & \\
\hline $2 / 11-1$ & $10050-11663$ & GR-ITT/ITT-GR & $3036-3528$ & 492 \\
\hline
\end{tabular}

\section{Leek Member}

\begin{tabular}{|c|c|c|c|c|}
\hline Well & $\begin{array}{l}\text { Depth b.KB } \\
\text { (feet) }\end{array}$ & $\begin{array}{l}\text { Log } \\
\text { (characterizing) }\end{array}$ & $\begin{array}{l}\text { Depth b.MSL } \\
\text { (m) }\end{array}$ & $\begin{array}{l}\text { Thickness } \\
\text { (m) }\end{array}$ \\
\hline A-2 & absent & & & \\
\hline Adda-1 & $8310-8478$ & GR-ITT/ITT-GR & $2499-2550$ & 51 \\
\hline Adda-2 & 8763- 8997?(TD) & GR-ITT/- & $2636-2708$ & $71(?)$ \\
\hline Bo-1 & $8302-8348$ & GR-ITT/GR-ITT & $2497-2511$ & 14 \\
\hline E-1 & 9546- 9726 & GR-ITT/ITT-GR & $2872-2927$ & 55 \\
\hline E-3 & not drilled & & & \\
\hline G-1 & absent & & & \\
\hline $1-1$ & $10802-11018$ & GR-ITT/ITT-GR & $3255-3321$ & 66 \\
\hline Lulu-1 & absent & & & \\
\hline $\begin{array}{l}\text { M-1 } \\
\text { M-8 }\end{array}$ & $\begin{array}{l}\text { absent } \\
\text { absent }\end{array}$ & & & \\
\hline O-1 & $?$ & & & \\
\hline Q-1 & $13100-13139$ & GR-ITT/GR-ITT & $3955-3967$ & 12 \\
\hline Tove-1 & absent & & & \\
\hline $\mathrm{U}-1$ & absent & & & \\
\hline $\mathrm{V}-1$ & absent & & & \\
\hline Vagn-2 & absent & & & \\
\hline W-1 & absent & & & \\
\hline $2 / 11-1$ & $11482-11663$ & GR-ITT/ITT-GR & $3473-3528$ & 55 \\
\hline
\end{tabular}


Vyl Formation

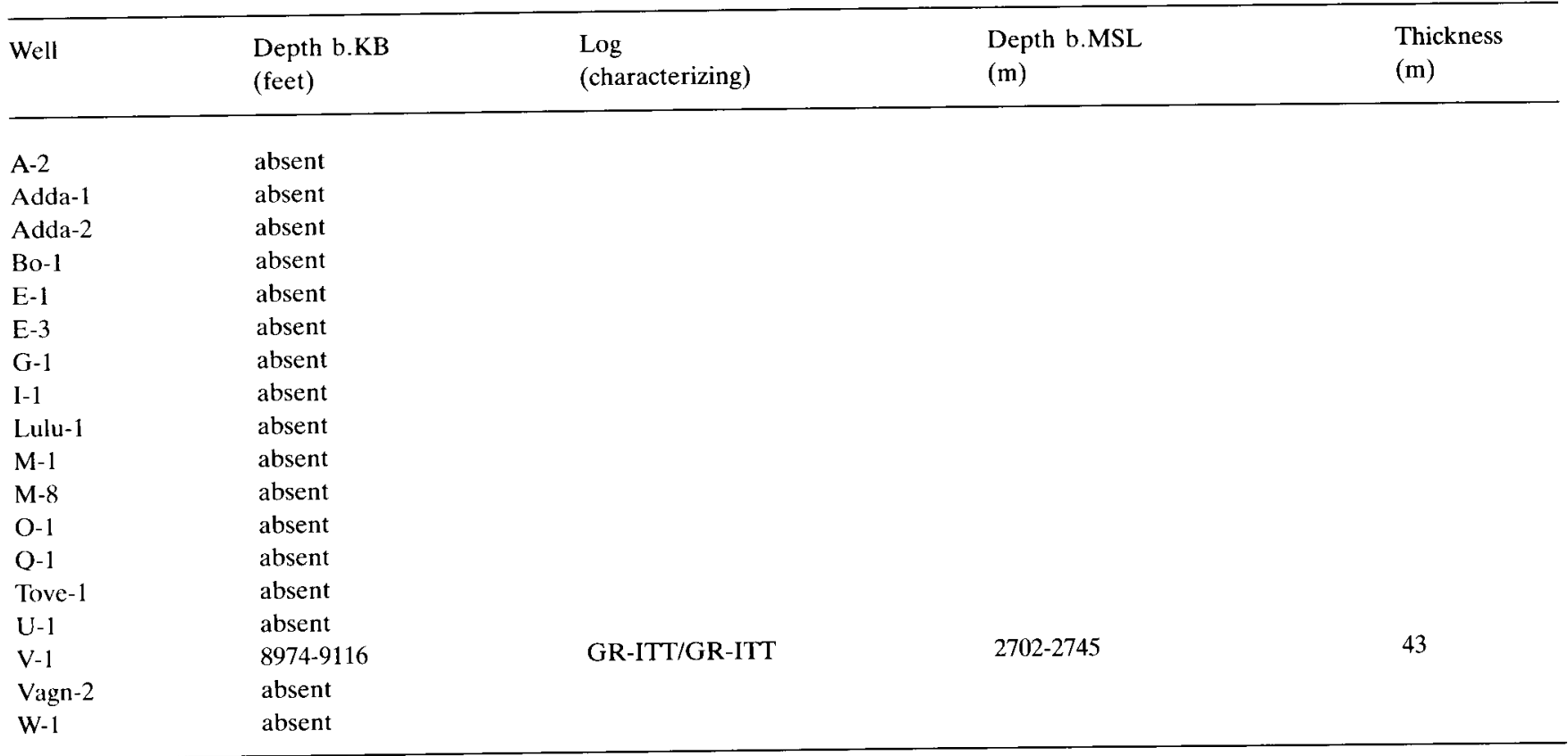

\section{Tuxen Formation}

\begin{tabular}{|c|c|c|c|c|}
\hline Well & $\begin{array}{l}\text { Depth b.KB } \\
\text { (feet) }\end{array}$ & $\begin{array}{l}\text { Log } \\
\text { (characterizing) }\end{array}$ & $\begin{array}{l}\text { Depth b.MSL } \\
\text { (m) }\end{array}$ & $\begin{array}{l}\text { Thickness } \\
\text { (m) }\end{array}$ \\
\hline A-2 & $7240-7280$ & mudlog/mudlog & $2171-2183$ & 12 \\
\hline Adda-1 & 7636- 7700 & GR-ITT/GR-ITT & $2293-2313$ & 20 \\
\hline Adda-2 & $7777-7854$ & GR-ITT/GR-ITT & $2336-2359$ & 23 \\
\hline Bo-1 & 7718- 7896 & $\begin{array}{l}\text { GR-(FDC-CNL)/ } \\
\text { GR-(FDC-CNL) }\end{array}$ & 2319-2373 & 54 \\
\hline E-1 & $8218-8296$ & GR-ITT/GR-ITT & $2468-2491$ & 24 \\
\hline E-3 & $8348-8497$ & GR-(ITT)/GR-ITT & $2514-2559$ & 45 \\
\hline G-1 & absent & & & \\
\hline I-1 & $9507-9798$ & GR/GR-ITT & $2861-2949$ & 89 \\
\hline Lulu-1 & absent & & & \\
\hline M-1 & absent ? & & & \\
\hline M-8 & absent & & & \\
\hline $0-1$ & $?$ & & & \\
\hline Q-1 & $13012-13050$ & GR/GR & $3929-3940$ & 12 \\
\hline Tove-1 & absent & & & \\
\hline U-1 & $8108-8150$ & GR-ITT/GR-ITT & $2443-2456$ & 13 \\
\hline V-1 & $8935-8945$ & GR-ITT/GR-ITT & $2690-2693$ & 3 \\
\hline Vagn-2 & absent & & & \\
\hline W-1 & absent & & & \\
\hline $2 / 11-1$ & $9803-10050$ & GR-ITT/GR-ITT & $2961-3036$ & 75 \\
\hline
\end{tabular}




\section{Sola Formation}

\begin{tabular}{|c|c|c|c|c|}
\hline Well & $\begin{array}{l}\text { Depth b.KB } \\
\text { (feet) }\end{array}$ & $\begin{array}{l}\text { Log } \\
\text { (characterizing) }\end{array}$ & $\begin{array}{l}\text { Depth b.MSL } \\
\text { (m) }\end{array}$ & $\begin{array}{l}\text { Thickness } \\
\text { (m) }\end{array}$ \\
\hline A-2 & absent & & & \\
\hline Adda 1 & $7527-76.36$ & GR-IT'V/GR-I'TI & $2260-2293$ & 33 \\
\hline Adda-2 & $7760-7777$ & GR-ITT/GR-ITT & $2331-2336$ & 5 \\
\hline Bo-1 & 7618- 7718 & GR-ITT/GR-(FDC-CNL) & $2289-2319$ & 30 \\
\hline E-1 & $8162-8218$ & GR-ITT/GR-ITT & $2451-2468$ & 17 \\
\hline E-3 & $8302-8348$ & FDC-CNL/GR-(ITT) & $2500-2514$ & 14 \\
\hline $\mathrm{G}-1$ & absent & & & \\
\hline I-1 & 9381- 9507 & GR-ITT/GR & $2822-2861$ & 38 \\
\hline Lulu-1 & absent & & & \\
\hline M-1 & $6901-6915$ & GR-ITT/GR-ITT & $2070-2074$ & 4 \\
\hline M-8 & $? \quad-7253$ & $/ \mathrm{GR}$ & $? \quad-2181$ & $?$ \\
\hline O-1 & $?$ & & & \\
\hline Q-1 & $\begin{array}{ll}? & -13012\end{array}$ & $/ G R$ & $? \quad-3929$ & $?$ \\
\hline Tove-1 & absent & & & \\
\hline U-1 & absent & & & \\
\hline$V-1$ & absent & & & \\
\hline Vagn-2 & absent & & & \\
\hline W-1 & absent & & & \\
\hline $2 / 11-1$ & $9548-9803$ & GR-ITT/GR-ITT & $2883-2961$ & 78 \\
\hline
\end{tabular}

\section{Rødby Formation}

\begin{tabular}{|c|c|c|c|c|}
\hline Well & $\begin{array}{l}\text { Depth b.KB } \\
\text { (feet) }\end{array}$ & $\begin{array}{l}\text { Log } \\
\text { (characterizing) }\end{array}$ & $\begin{array}{l}\text { Depth b.MSL } \\
(\mathrm{m})\end{array}$ & $\begin{array}{l}\text { Thickness } \\
(\mathrm{m})\end{array}$ \\
\hline A-2 & absent & & & \\
\hline Adda-1 & $7512-7527$ & ITT-GR/GR-ITT & $2256-2260$ & 5 \\
\hline Adda-2 & $7707-7760$ & GR-ITT/GR-ITT & $2314-2331$ & 16 \\
\hline Bo-1 & $7474-7618$ & GR-(ITT)/GR-ITT & $2245-2289$ & 44 \\
\hline E-1 & absent & & & \\
\hline E-3 & absent & & & \\
\hline G-1 & absent & & & \\
\hline I-1 & $9355-9381$ & GR-ITT/GR-ITT & $2814-2822$ & 8 \\
\hline Lulu-1 & absent & & & \\
\hline M-1 & $6858-6901$ & GR-ITT/GR-ITT & $2057-2070$ & 13 \\
\hline M-8 & $7190-?$ & GR-ITT/ & $2162-?$ & ? \\
\hline $\mathrm{O}-1$ & $?$ & & & \\
\hline Q-1 & $13000-?$ & GR-ITT/ & $3925-?$ & $?$ \\
\hline Tove-1 & $6097-6121$ & GR-ITT/GR-ITT & $1825-1832$ & 7 \\
\hline U-1 & absent & & & \\
\hline$V-1$ & absent & & & \\
\hline Vagn-2 & $5881-5932$ & ITT-GR/GR-ITT & $1760-1775$ & 16 \\
\hline W-1 & absent & & & \\
\hline $2 / 11-1$ & $9473-9548$ & GR-ITT/GR-ITT & $2861-2883$ & 23 \\
\hline
\end{tabular}


This paper presents a new lithostratigraphic nomenclature of the Jurassic and Lower Cretaceous sequences in the Danish Central Trough. 